\title{
ظاهرة التكرار
}

\section{في مراتي الملك الصسالح خـالد بن عبد العزيز آل سعود الصراد دراسـة أسـلوبية}

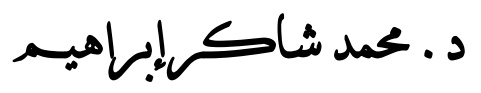

أستاذ الأدب والنقد المساعد

بكلية الآداب والتربية للبنات بأبكا

جامعة الملك خالد

هـ:مندم

الحمد للّ رب العالمين ، وصلاة وسلامًا على خاتم النبيين ، وإمام المرسلين، المبعوث رحمة للعالمين ، و بعد ..... فقد اقتضت حر كة الحياة لدى الناهين أن تكون أعمالهم فيها سجلًا شاهدًا لهم وذكرى خالدة بعد مماهم ، وصفحات مضيئة يو لقاء رهم .

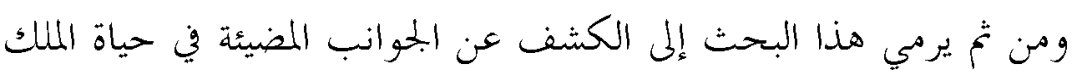

$\overline{3}$

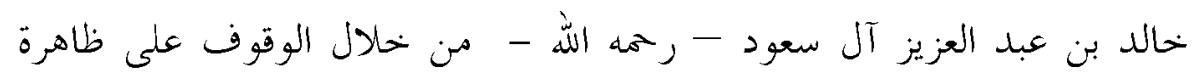

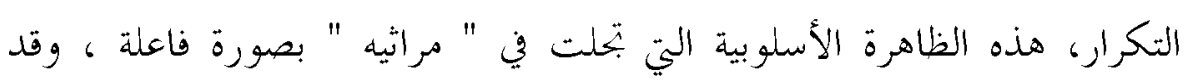

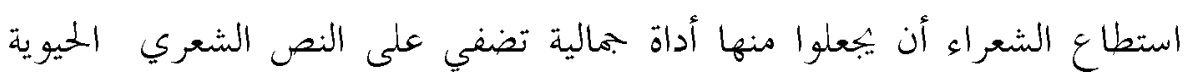
والإيقاع بما بمنحه خصوصية في الأداء ، وتميزًا في تشكيل البنية ، ووضوح الدلالة. وبذلك فقد ساهت بنية التكرار في إبراز مناقبه ومآثره الخالدة التي لا تبلي جدها الأيام ، فنراها نبراسًا يضيء لشباب أمتنا الطريق ويبدد ظلماته، كما نراها معالًَ واضحة لمن أراد التأسي والسير على خطى الصالم الحين.

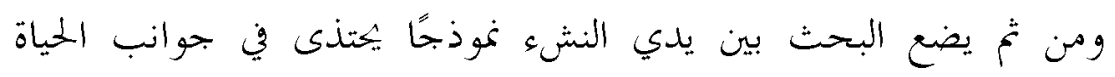

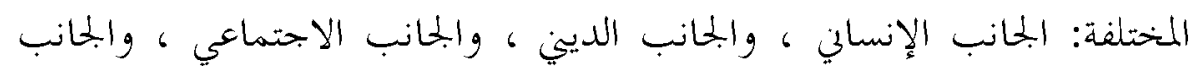

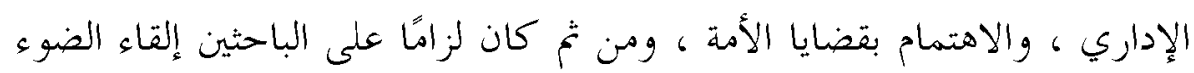

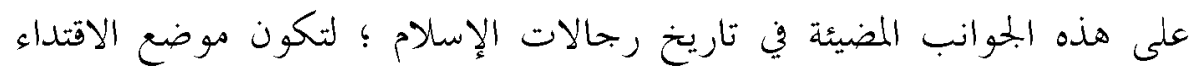


لشباب أمتنا عامة ، وقادتنا خاصة الذين حملوا عبع النهوض بمستقبل هذه الأمة ،

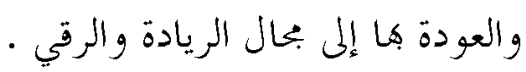
ويقوم البحث على المنهج اللغوي الأسلوبي في الكشف عن الكن المثيرات اللغوية

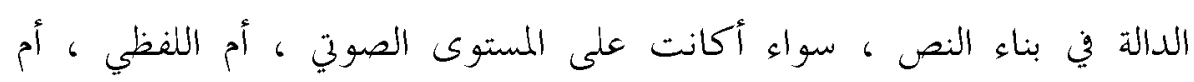
التركيبي، والوقوف عند أثر ظاهرة تكرار هذه المثيرات اللغوية في تشكيل الرؤية وبناء الدلالة. وقد أفدت في دراسة النص الأدبي وما فيه من معنى وعاطفة وخيال ، من دراسة الأحوال النفسية ، والمتغيرات الاجتماعية ، والاستعانة كذلك بالدراسات

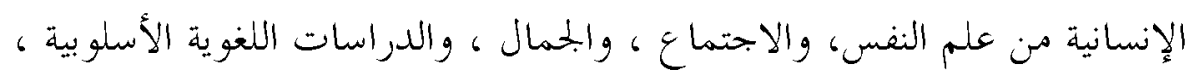
و كلها دراسات لا غنى عنها في إثراء الدراسات الأدبية التحليلية . وكذا أفدت في بكثي من دراسة الأساتذة الرواد : الأستاذ الدكتور زهير أحمد

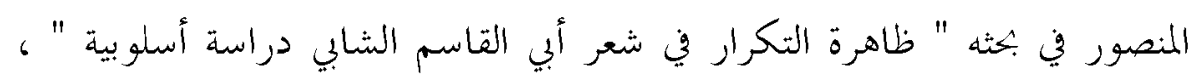

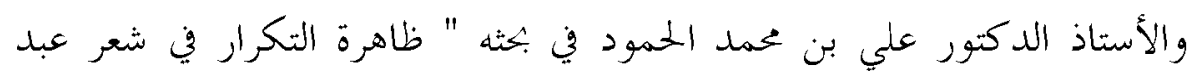
الرحمن العشماوي ديوان عناقيد الضياء أنموذجًا " . وقد صدّرت البحث بتمهيد يعطي صورة موجزة عن حياة الملك خالد -

$$
\begin{aligned}
& \text { رحمه الله - ويوضح أهمية التكرار وصوره . } \\
& \text { ثم انتظمت هذه الدراسة - بعد ذلك - ثلاثة مباحث : } \\
& \text { المبحث الأول : التكرار الصوتي ، وتناولت فيه : } \\
& \text { - تكرار الحرف ن } \\
& \text { - القافية وخاصية التجانس الصوتي . } \\
& \text { - التصريع - } \\
& \text { المبحث الثاني : التكرار اللفظي ، وتناولت فيه : } \\
& \text { - - تكرار الاسم - }
\end{aligned}
$$




$$
\begin{aligned}
& \text { - الإحالة الضميرية . } \\
& \text { - تكرار الفعل ( الماضي ، والمضارع ، والأمر ) . } \\
& \text { المبحث الثالث : التكرار التركيي ، وتناولت فيه : } \\
& \text { - تكرار الجملة ( الاسمية ، والفعلية ) . }
\end{aligned}
$$

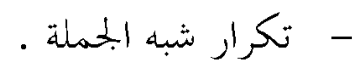

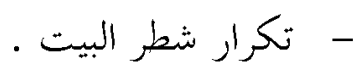

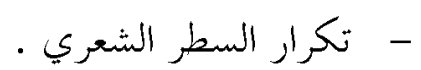

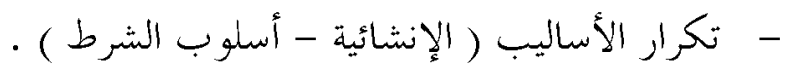

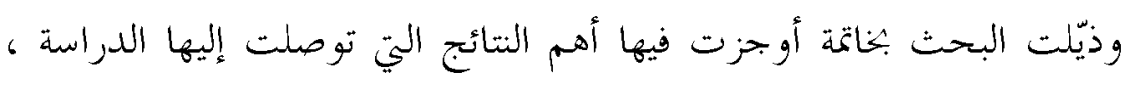

مُتبعًا ذلك بثبت المصادر والمراجع ، والفهرست العام .

$$
\text { وبعد }
$$

فهذا جهدي إن أصبت فالفضل لله وحده ، وإن كان ثمة تقصير ، فالكمال 0ـأ

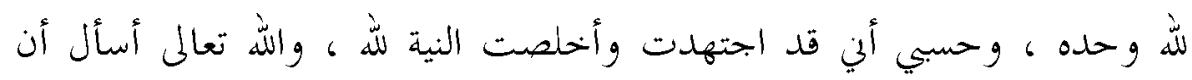

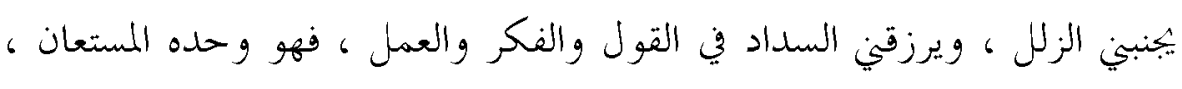
وهو حسبي ونعم الوكيل · 


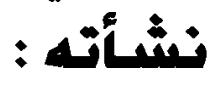

ولد الملك خالد - رحمه الله - في مدينة الرياض في ربيع الأول عام

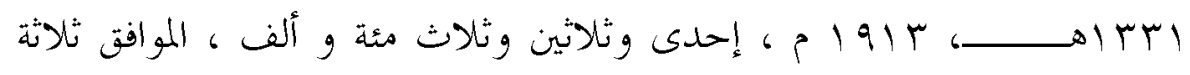
عشر وتسع مئة وألف للميلاد ، وهو خحامس أبناء الملك عبد العزيز طيب الله ثراه

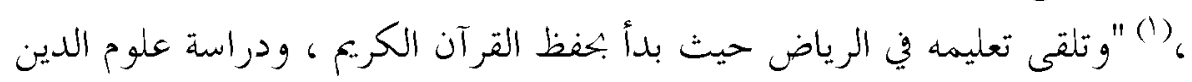

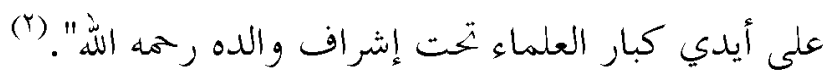
صفاته ومناقبه :

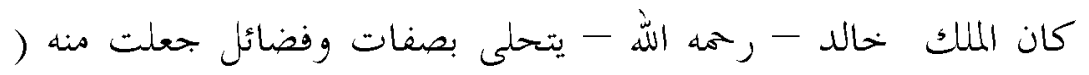

الملك الصالح ) الذي يسعى إلى خير بلده وأمته ودينه ، فهو منذ بلذ شبابه مثال

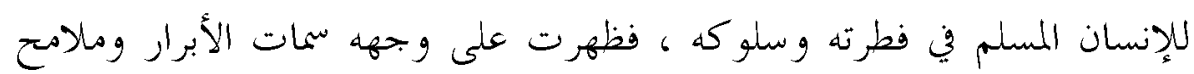

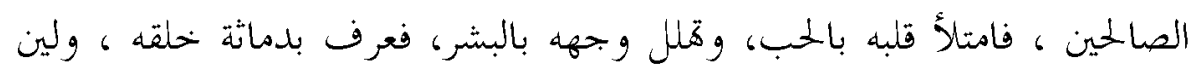

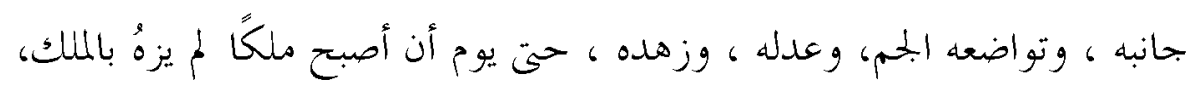

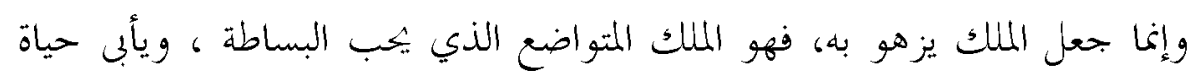
الترف و المظاهر الزائفة.

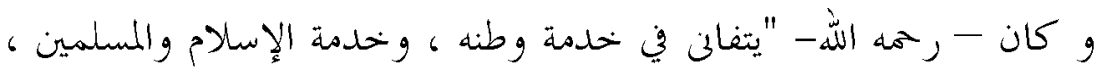

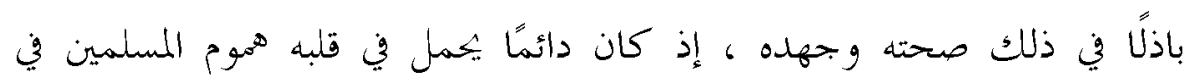

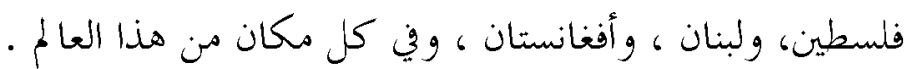

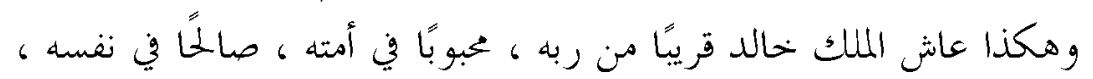

(") مصلحًا لغيره

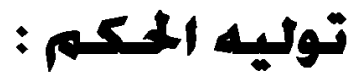

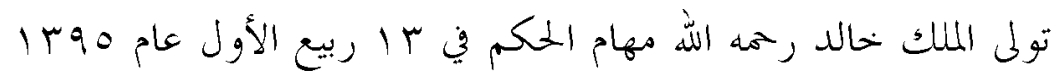

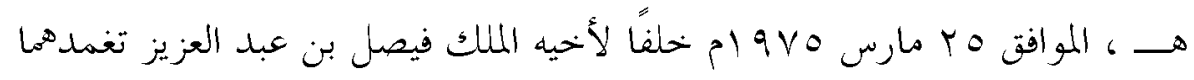

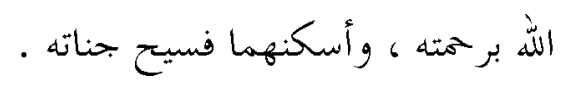
وأعلن جلالته حرصه الدائم على دعم وحدة الصف اله العربي وتماسكه ومساندة 


\section{ظاهرة التكرار}

القضايا الرئيسة للأمة العربية ، وعلى رأسها قضية فلسطين ، والسعي لاستعادة

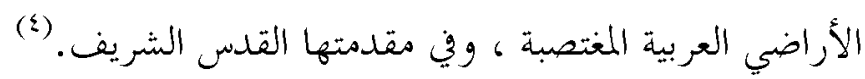

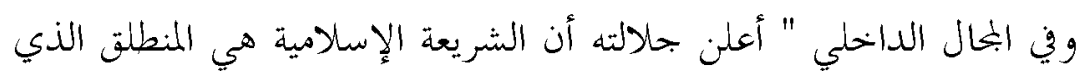
تسير منه المملكة في سياستها من أجل بلوغ النهضة الشاملة التي تسعى المملكة لتحقيقها في مختلف نواحي الحياة ". (o) وقد كان الملك خالد - رحمه الله - يرى أن من الواجب على على حكام

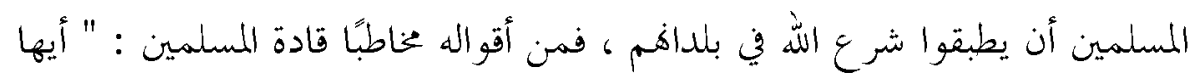

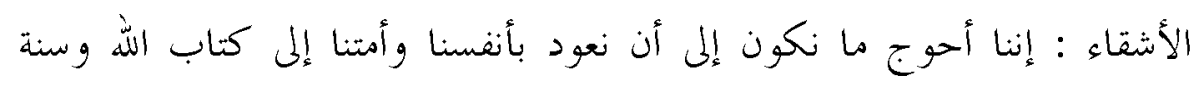
رسوله - صلى الله عليه وسلم - نخكمها فينا ، ونتهم إليها في كل شؤون

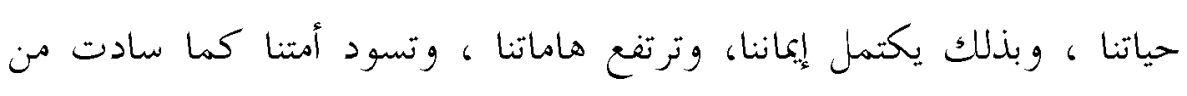
قبل ")

$: 4: \dot{0}$

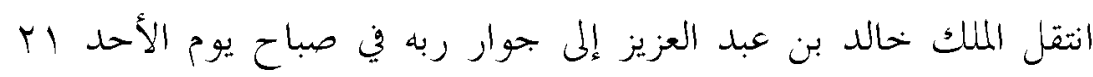

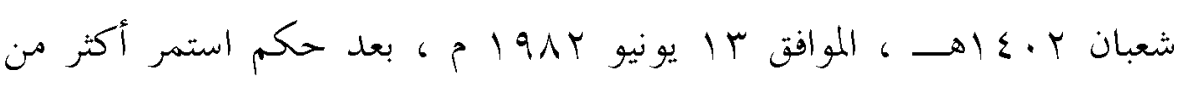

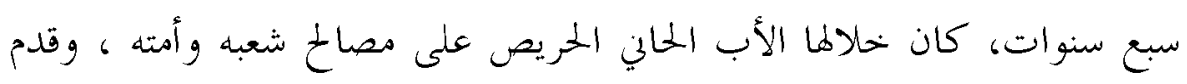

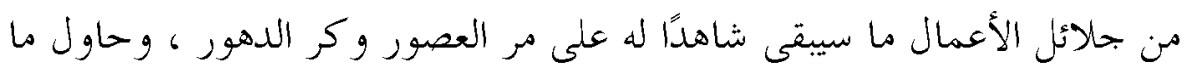

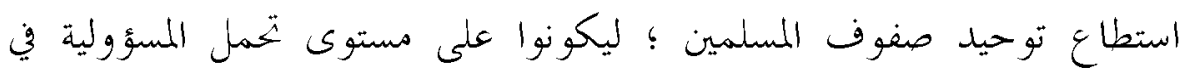

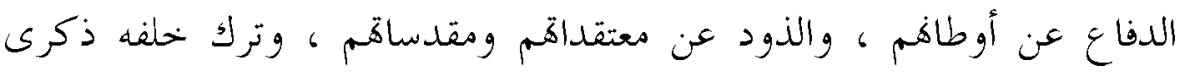

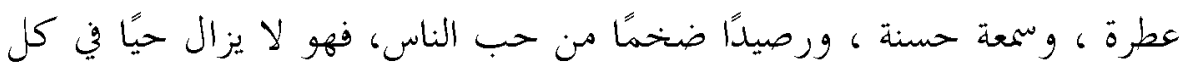

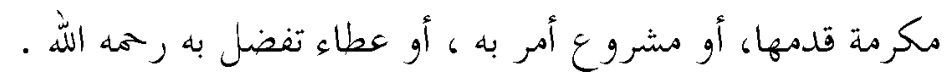

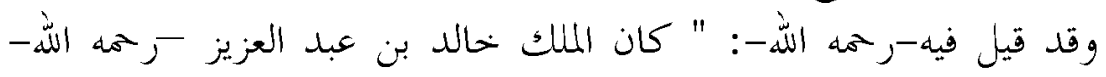
عظيمًا في كل شيء .. في تواضعه وقوته .. في مواجهته للأحداث . . في تأمله

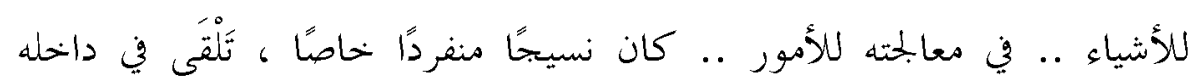
تواضع العظماء، وقوة العباقرة ، وصمود المقاتل ، وعطف الأب الرحيم ، وزهد 
ولذلك فإن التكريم الحقيقي الذي يبب أن بيكظى به الملك خالد " ألا ننسى

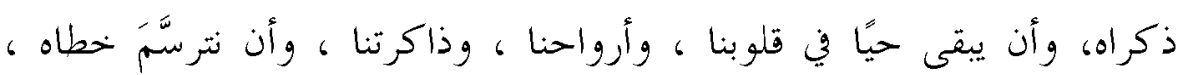

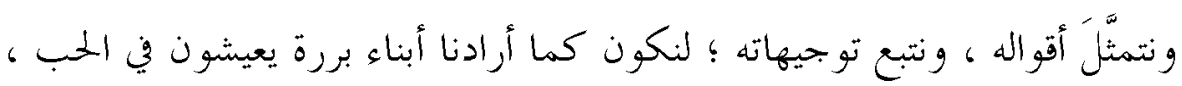

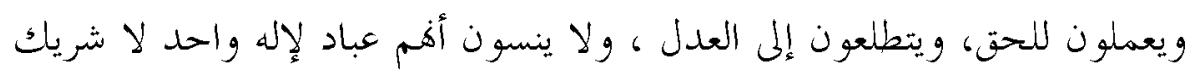

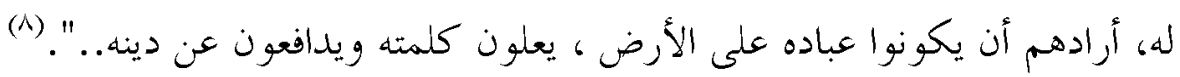

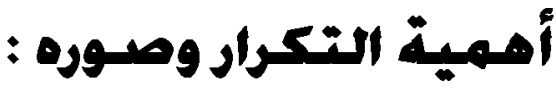

يعد التكرار من الظواهر الأسلوبية التي عُني هـا البلاغيون العرب القدامى،

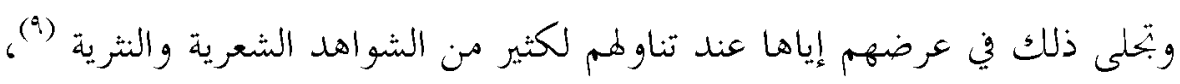

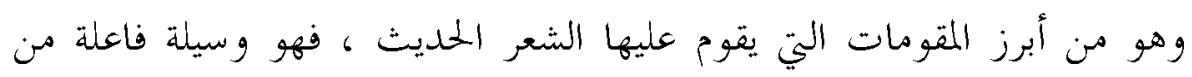

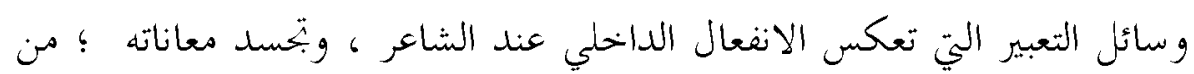
خلال الإلحاح على بعض الألفاظ ، والتراكيب ، والمعاني التي تسهم في بناء رؤيثه

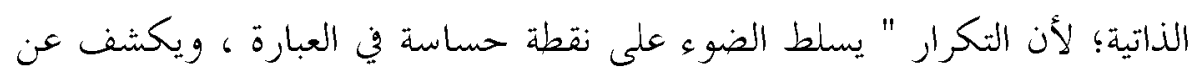

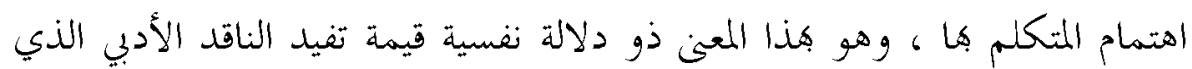

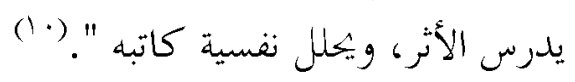

والتكرار يسهم بشكل فعال في بناء النص ؛ لأنه " من شأنه أن يخلق قدرًا

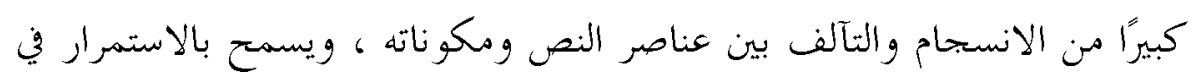

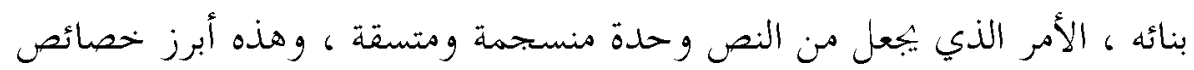
النص الفني ". (11) وتعد بنية التكرار من أبرز الوسائل الفنية التي تساعد دارس النص الأدبي على الفي

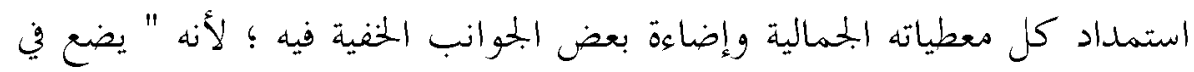
أيدينا مفتاحًا للفكرة المتسلطة على الشاعر ، وهو بذلك أحد الأضواء اللاشعورية

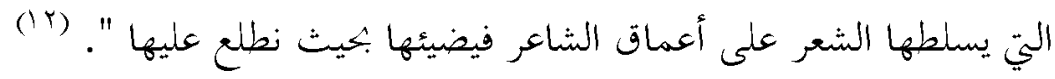
وعند دراسة الجانب الإيقاعي الموسيقي الذي يكتسبه النص من خحلال بنية 


\section{ظاهرة التكرار}

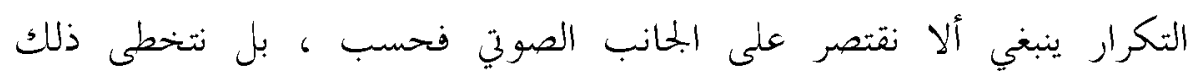

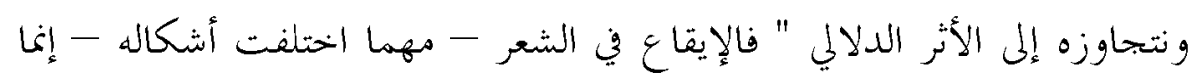

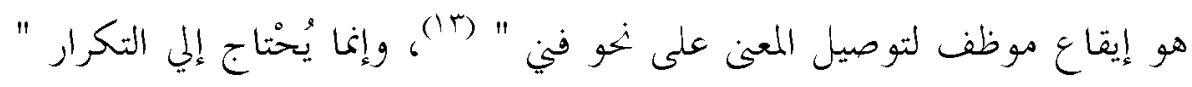

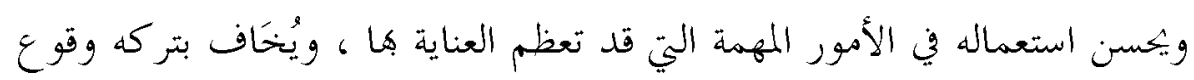

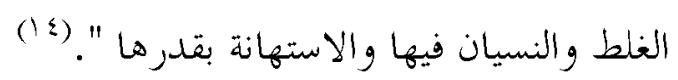

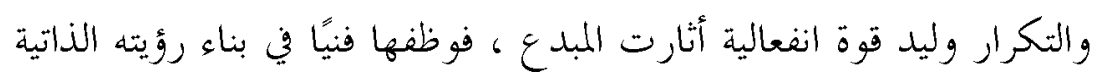

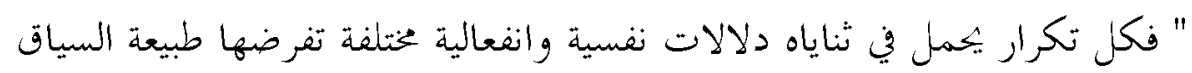

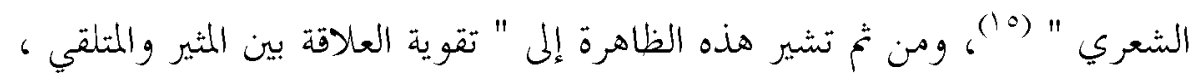

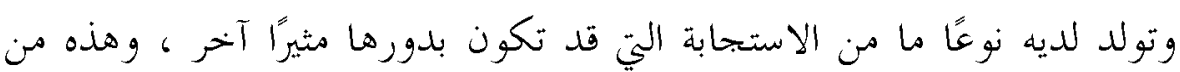

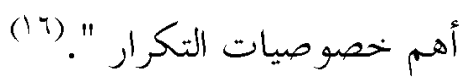

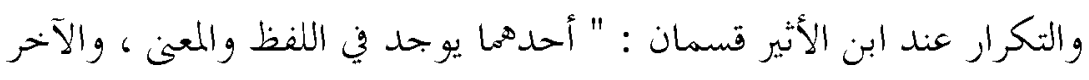

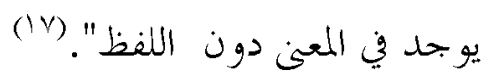

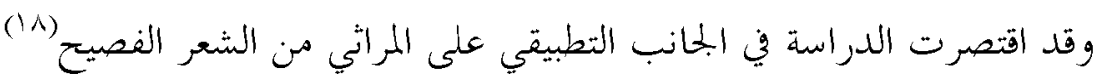

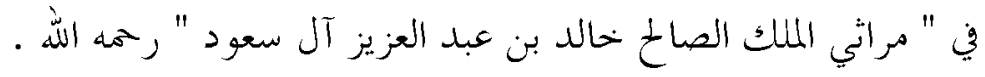

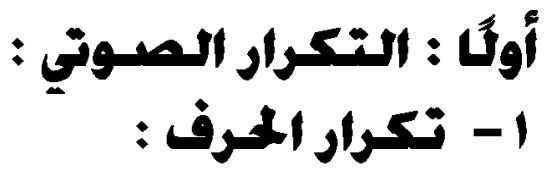

الصوت اللغوي جانب من جوانب عدة للغنتا العربية ، بل هو أحد أنظمة

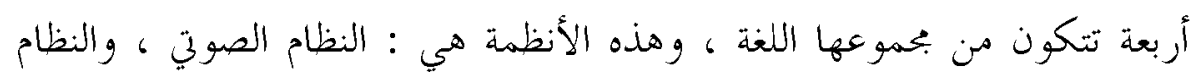

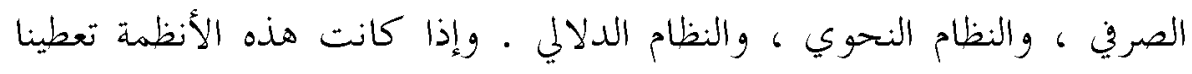

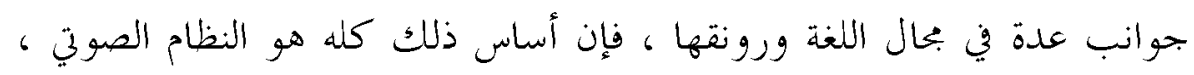

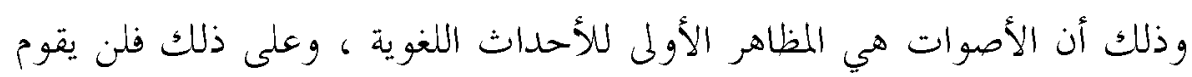

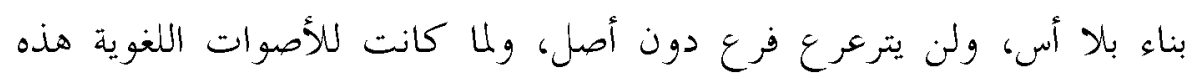

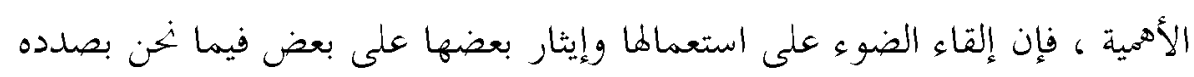

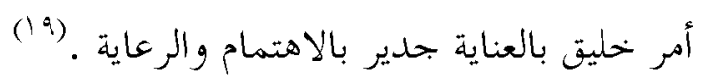


ومن خلال دراسة خصائص التشكيل الصوتي بند تركيز الشعراء على بعض

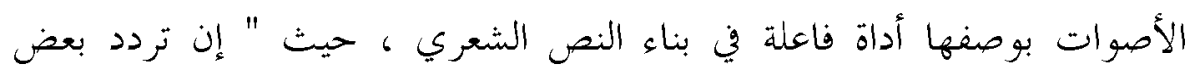
الحروف - أو الكلمات - قد يكسب الشطر لونًا من الموسيقى تستريح إليه

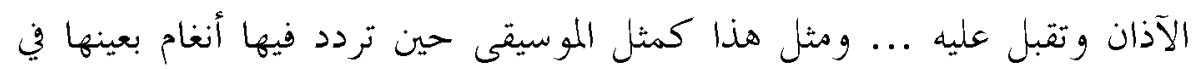

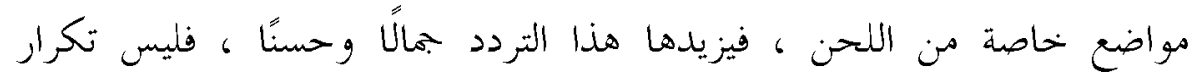

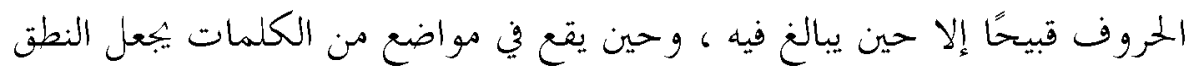

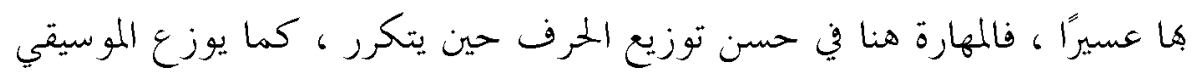
(r.) الماهر النغمات في نونته والتكرار الصوتي وحدة مميزة في بناء النص " إذ تعتمد بنية الشعر - أساسًا

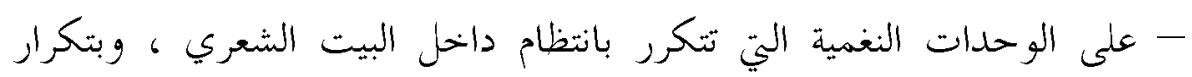

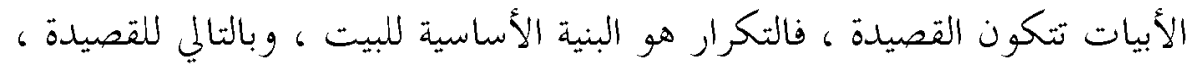

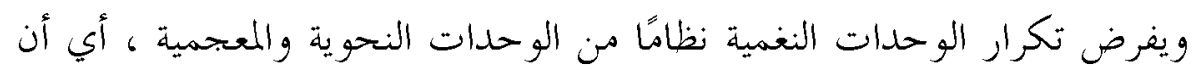

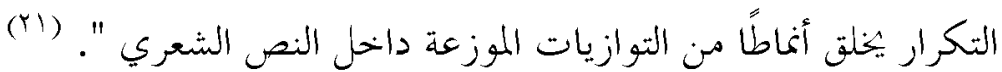

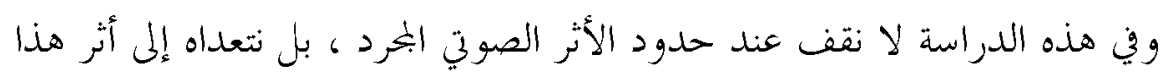

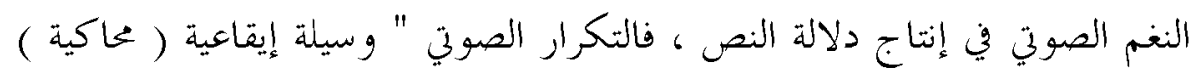

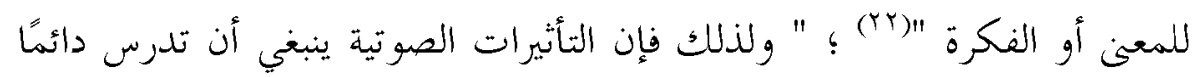

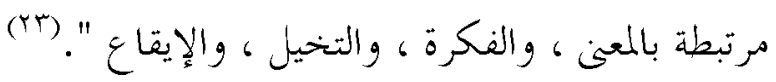

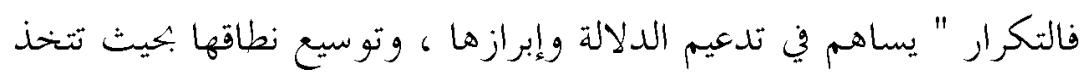

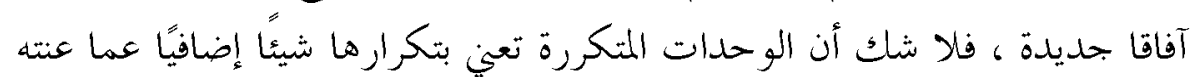

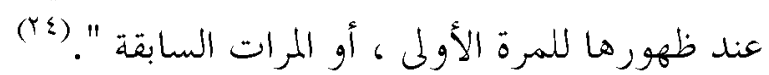

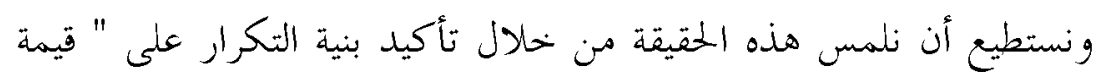
الدال اللغوي ودوره في بناء النص الشعري ، وفي فتح آفاق جديدة نهو تفجير إمكاناته النغمية والدلالية ، فالشاعر في غير بنية التكرار يعدل عن الدوال نفسها إلى دوال أخرى بديلة تخدم الدلالة الشعرية ، في حين أن استخدام بنية التكرار أي الوحدات اللغوية نفسها- يؤكد - إلى جانب ما توحي به - على أهميتها 
نفسها ، واعتمادها في بناء النص ." (ن)

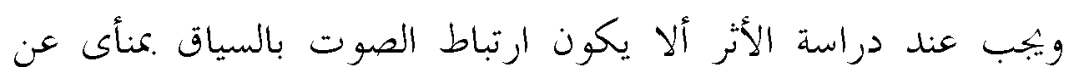

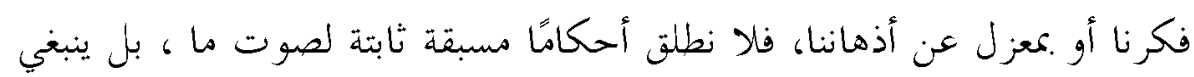

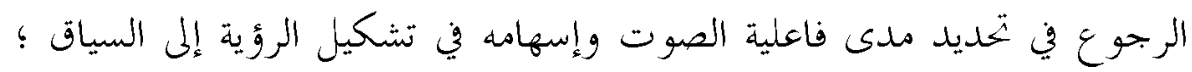

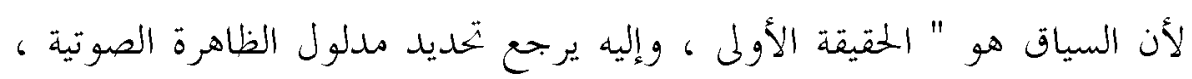

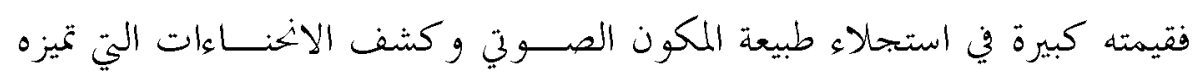

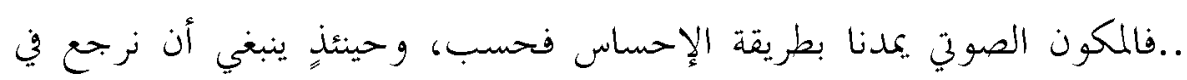

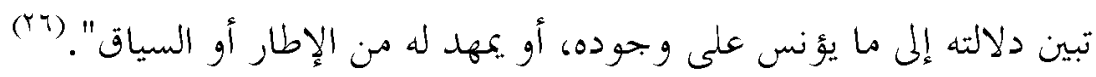

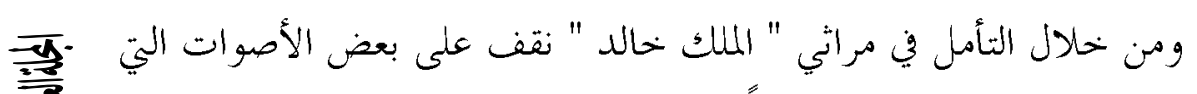

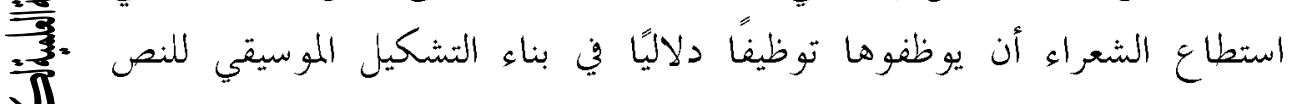
الشعري، يقول الشاعر : الشعان الشعان

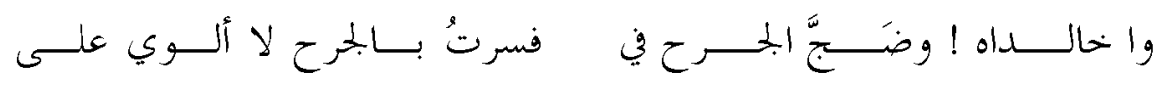

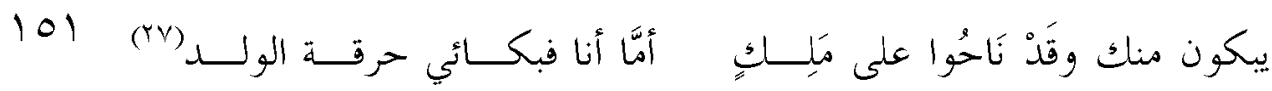

فتد خيمت ظلال الحزن والأسى على أجواء الصورة ، ساعد على ظهور

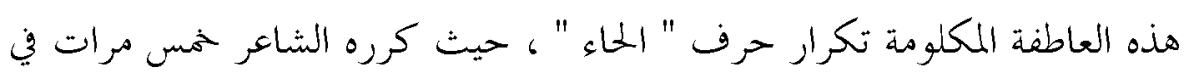

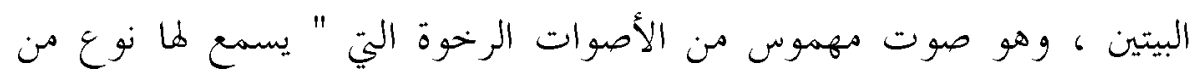

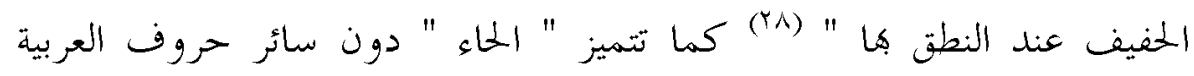

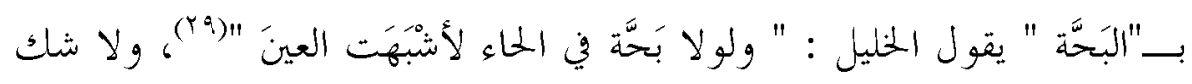

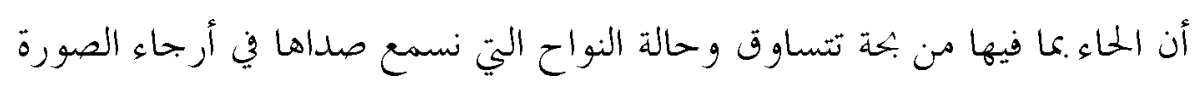

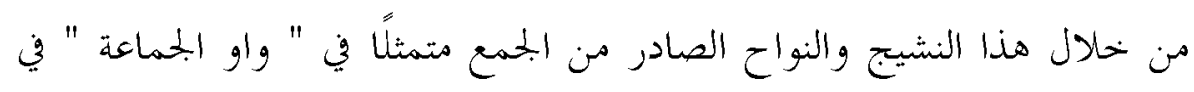

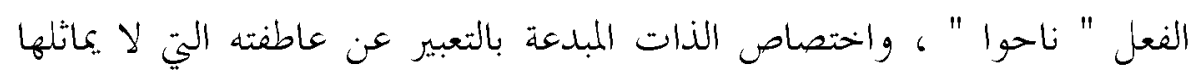
مصاب آخر ، متمثلةً فِيَ فَقْدِ الولد . ويقول الشاعر : 


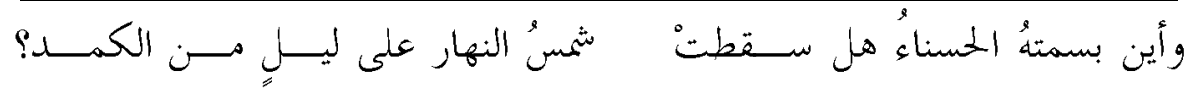

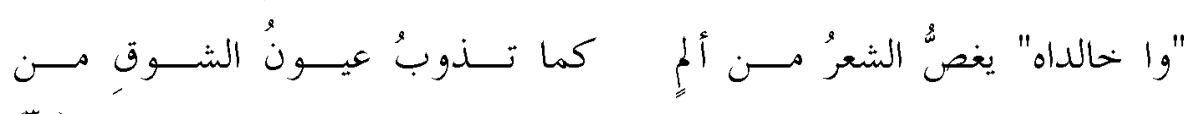

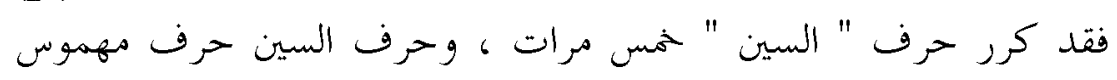

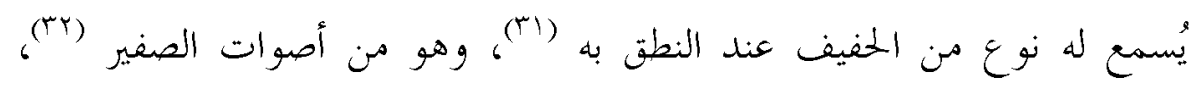

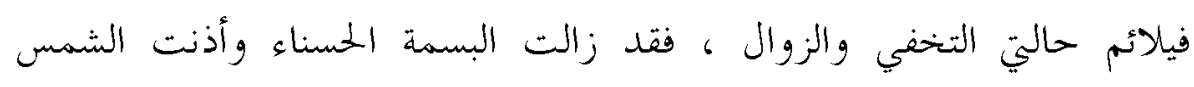

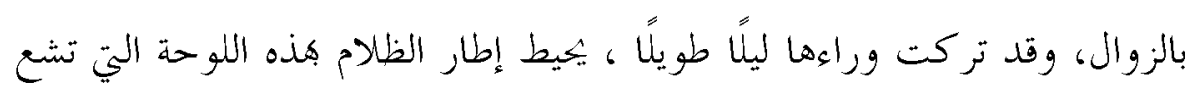
فيها عاطفة الحزن والأنين .

$$
\text { ويقول الشاعر : }
$$

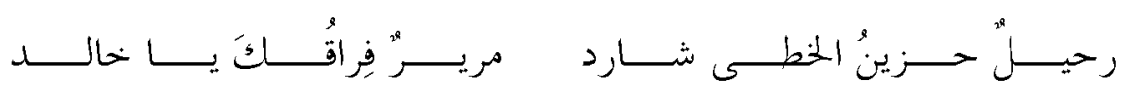

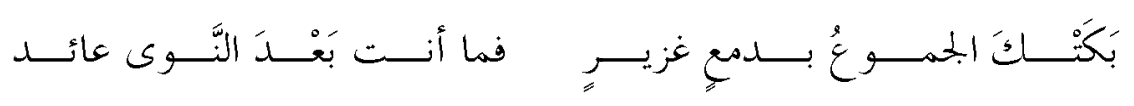

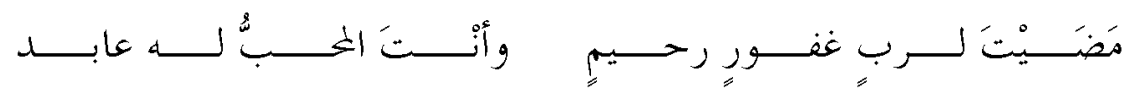

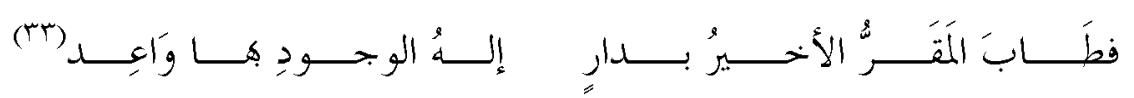

تكرر حرف الراء في الأبيات السابعة اثني عشرة مرة ، وهو من أوضح

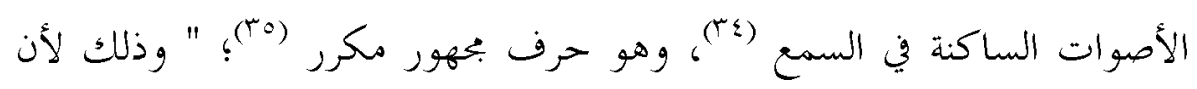

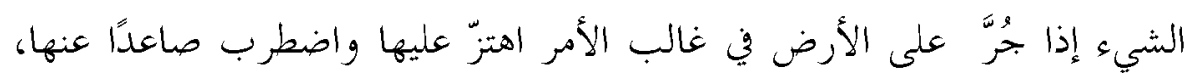

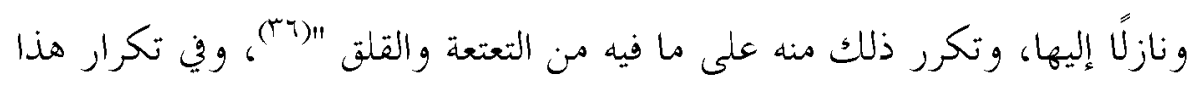

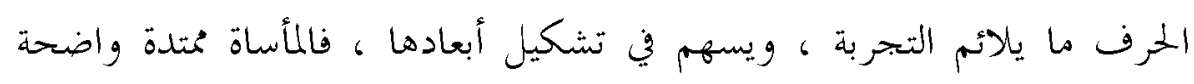

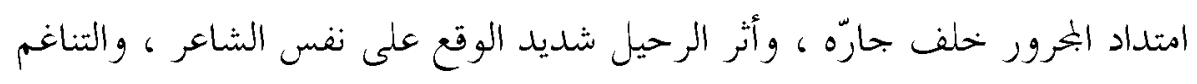

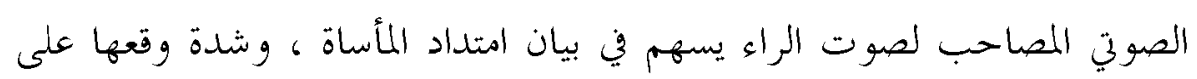

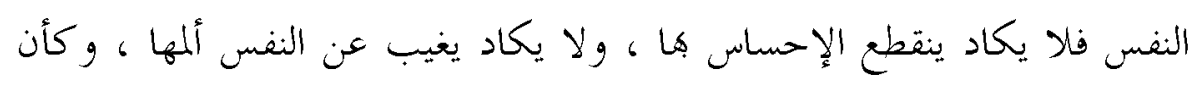

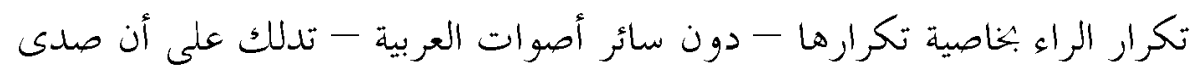

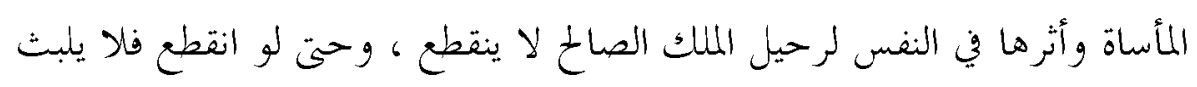




\section{ظـاهرة التكرار}

أن يعود مكررًا مرة ثانية ، حتى أصبح لتكرار رجوعه وعوده وتكرار ذلك مرة

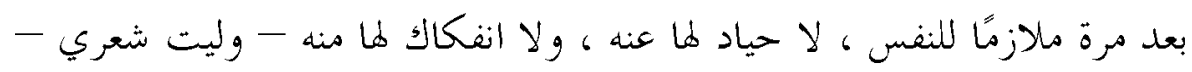

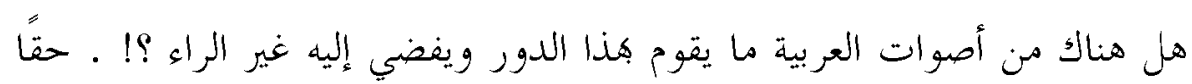

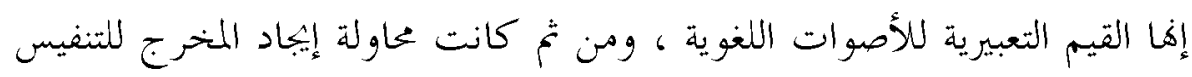
عن هذه المعاناة ، فكان الدعاء بالنعيم المقيم في دار الخلود التي وعد الرحمن هات عباده.

\section{ويقول الشاعر :}

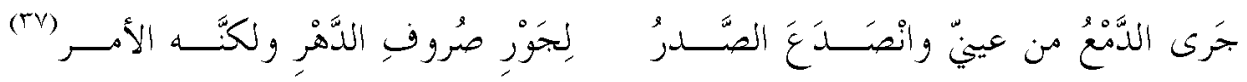
من خلال هذه الملامح التي ذكرناها لصوت الراء من الجهر ، والتكرار ، والوضوح السمعي ، والإيماء بالقلق والاضطراب ، ندرك أثر هذا التناغم الإيقاعي مني

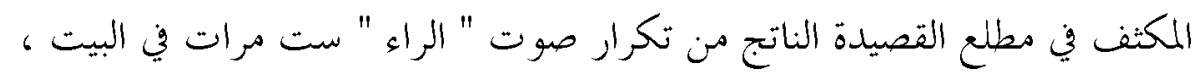

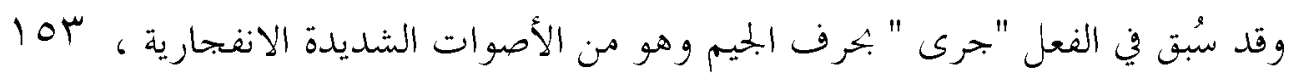

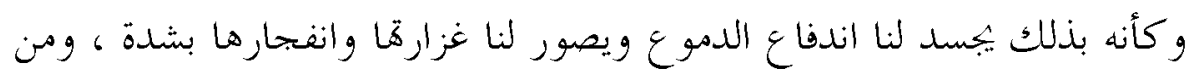
ثز ندرك مدى الاضطراب الداخلي في أعماق الشاعر إزاء تقلبات الزمن ، ولكن الرضا بالقضاء والقدر هو السلاح الذي بمكن به مواجهة هذه الأزمة . ويقول الشاعر :

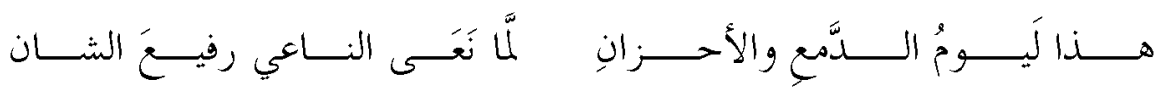

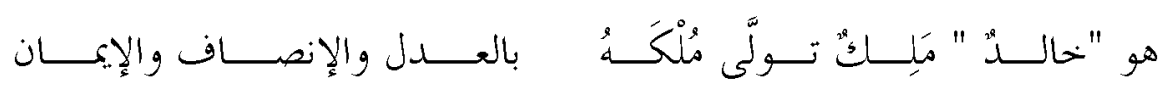

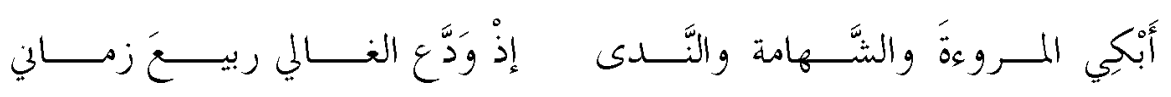

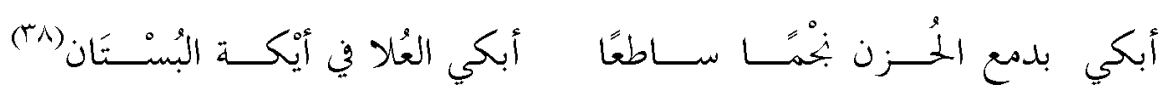
فقد تكرر حرفا " الألف " و " الياء " كثيراً في الأبيات ، فتكرر حرف

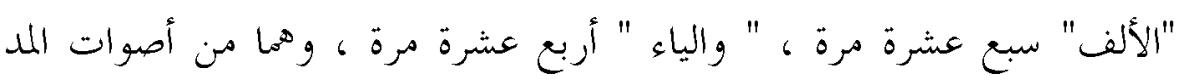


واللين ، ولأصوات المد واللين دور مؤثر في بناء التشكيل الإيقاعي " فالأصوات

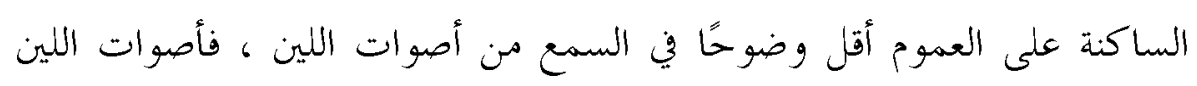

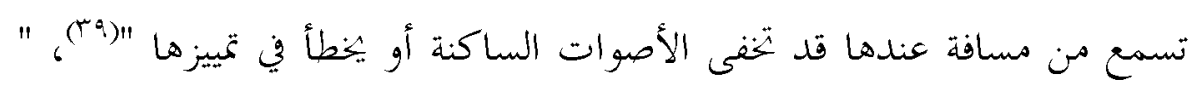
والوضوح السمعي الذي بنيت عليه التغرقة بين الأصوات الساكنة وأصوات اللين،

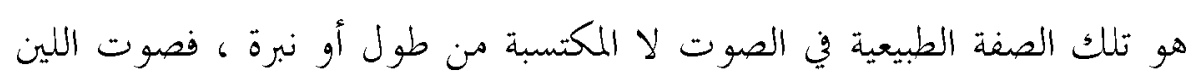

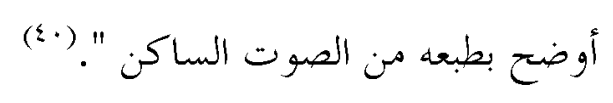

وأصوات اللين بالإضافة إلى الجانب الإيقاعي ، فإها تعمد إلى جانب دلالي يسهم في وضوح المعنى وتصوير انفعال المبدع عن طريق الامتداد الصوتي الذي إلي

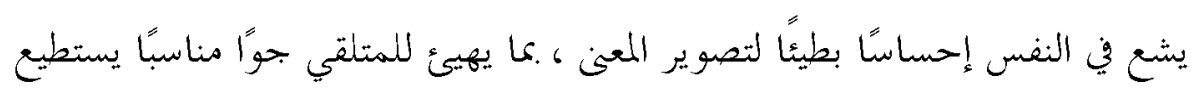

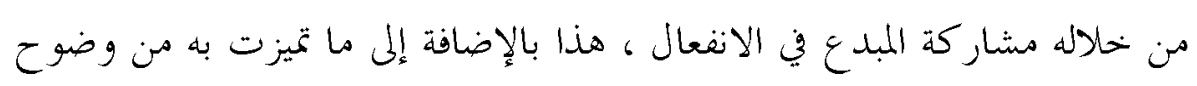

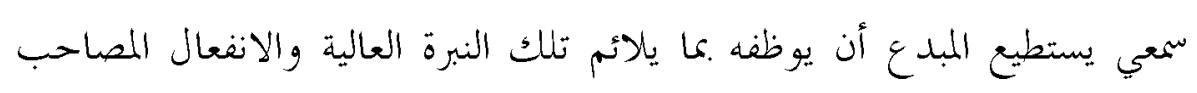

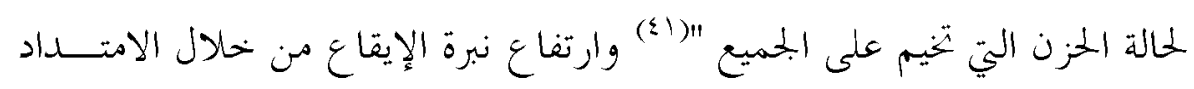
الصوتي ، و كذلك تلك الصفة الجهرية التي تلائم الانفعال (من المبدع وإلى المتلقي) ومن تم تفاعلت البنية الإيقاعية مع دلالتها في وضوح الرؤية،وتشكيل أبعاد هذه الخحنة الإنسانية العامة.

وقد تكرر في الأبيات السابقة حرف "النون " و" التنوين " سبع عشرة مرة،

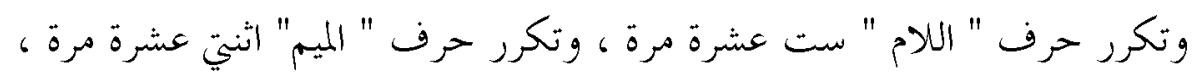

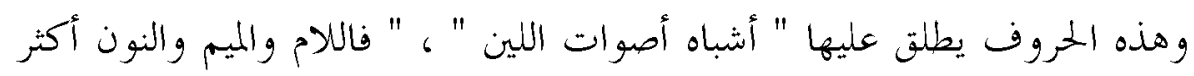

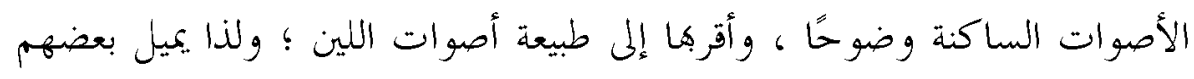

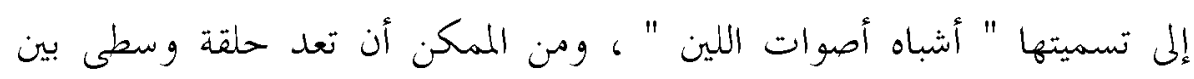

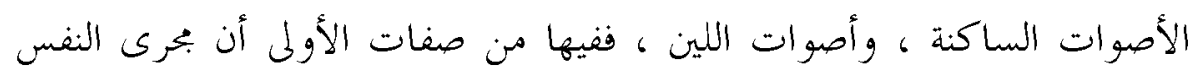

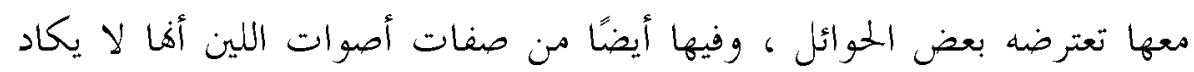

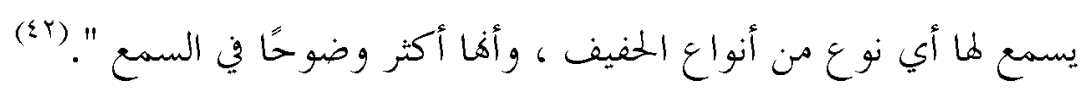

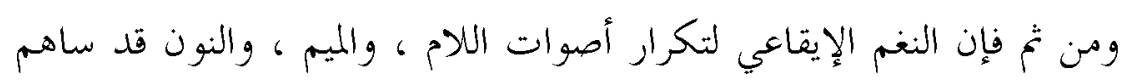


في وضوح الدلالة وعلو نبرة النواح في الأبيات .

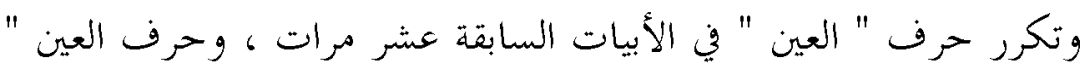

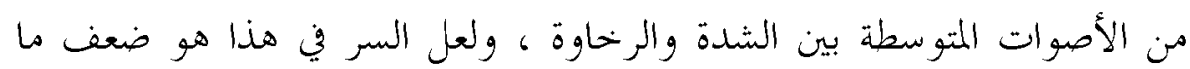

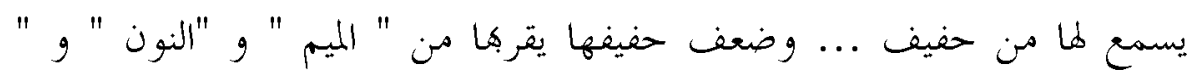

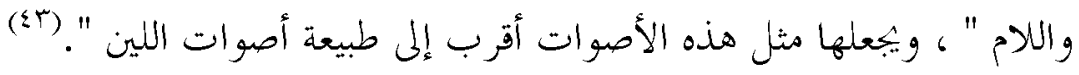

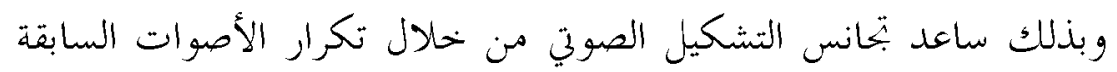

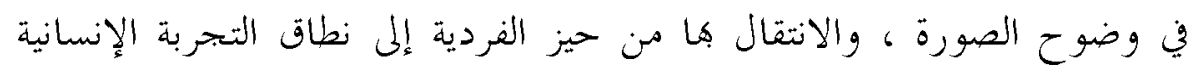

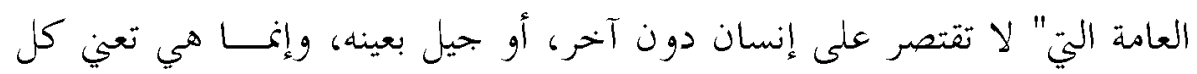

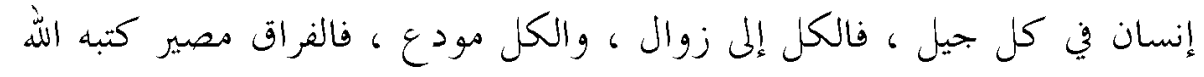

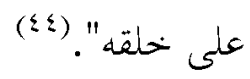

弯

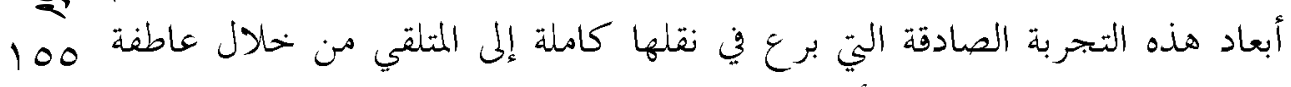

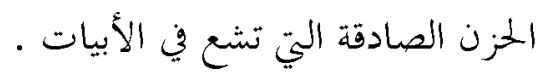

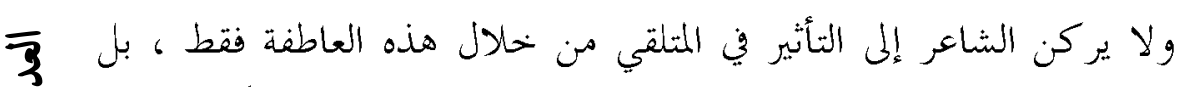

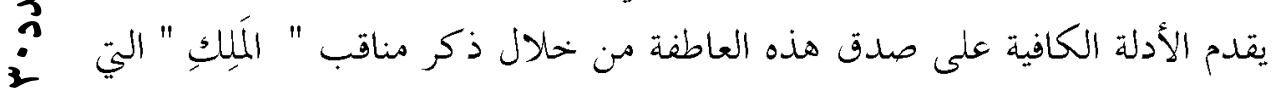

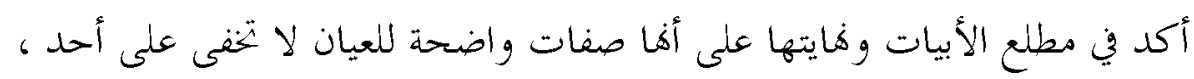

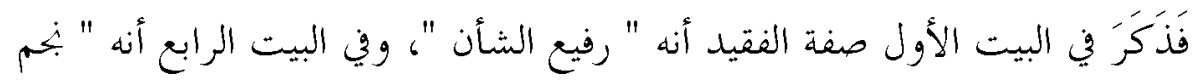

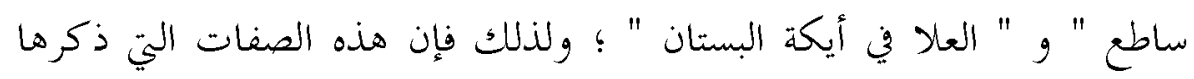

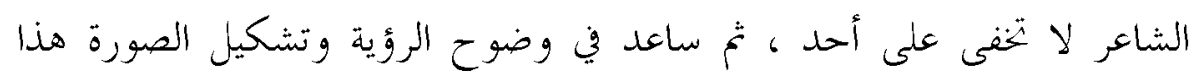

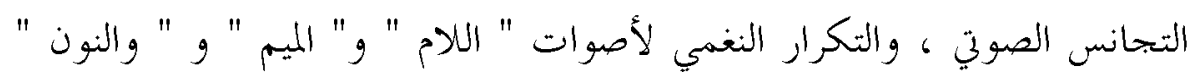

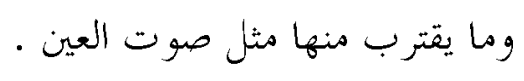
ويقول الشاعر : ونتر
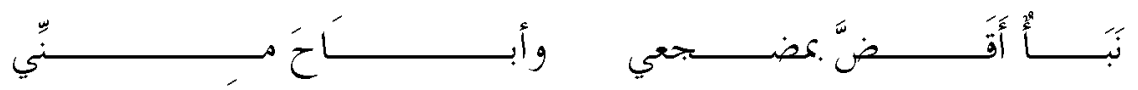

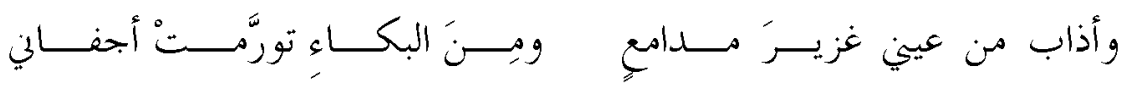




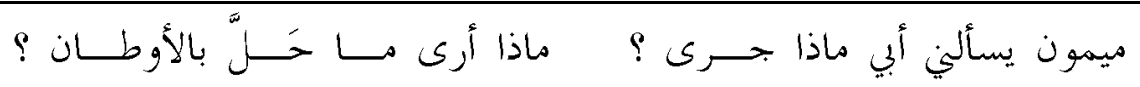

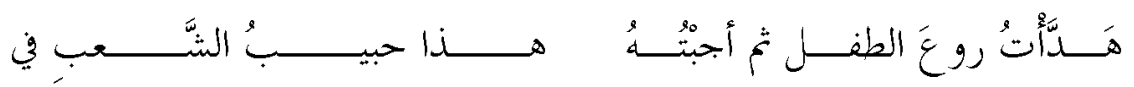

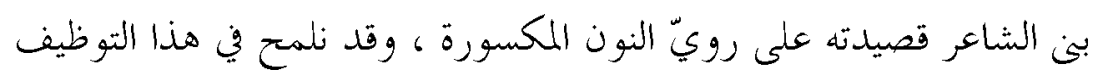

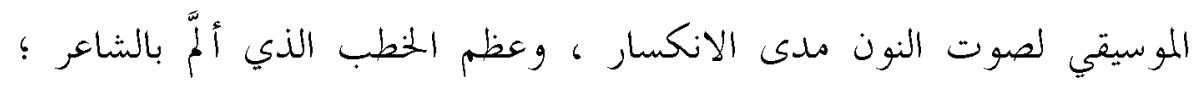

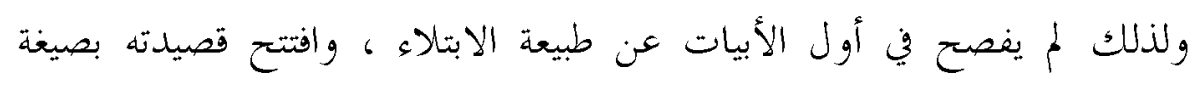

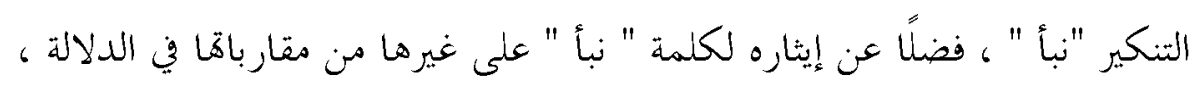

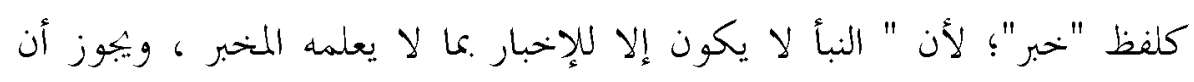

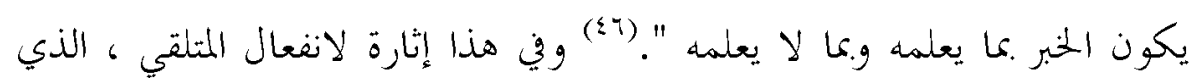

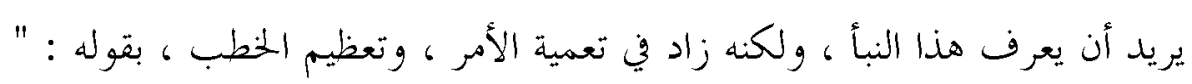

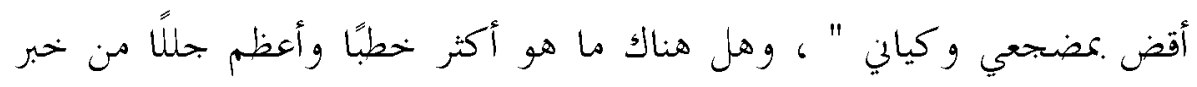

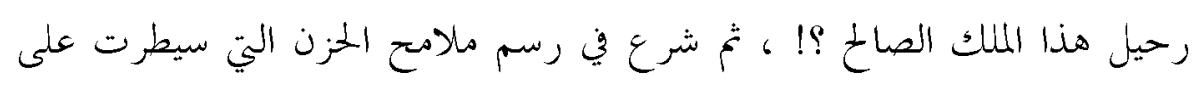

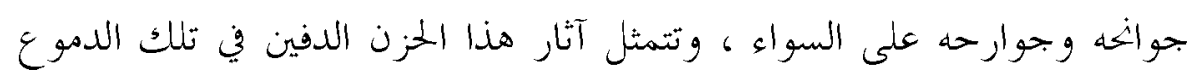
المنهمرة ، وفي تلك الأجفان المتورمة .

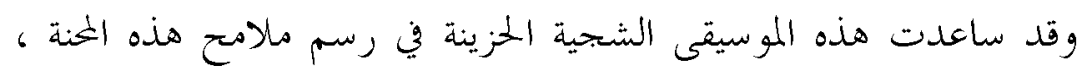

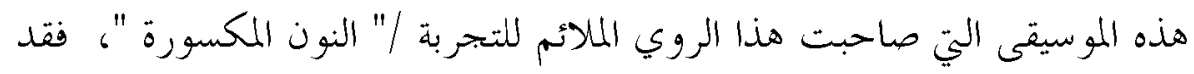

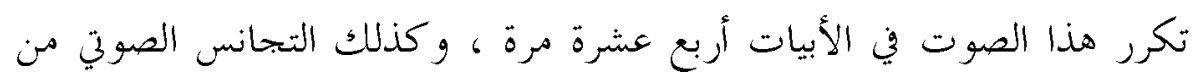

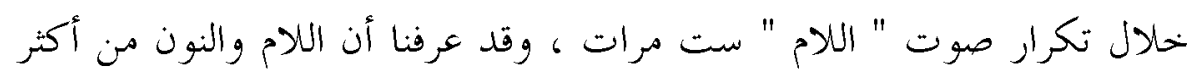

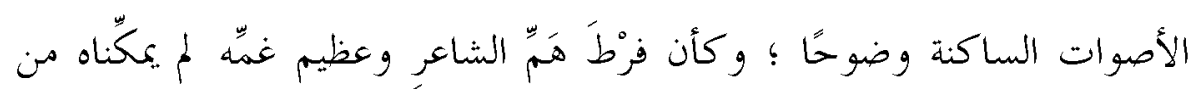

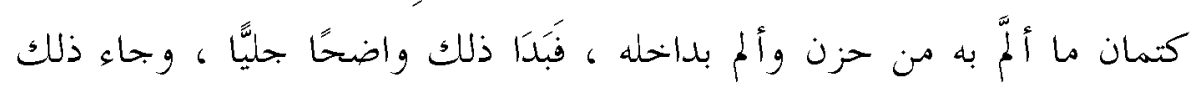

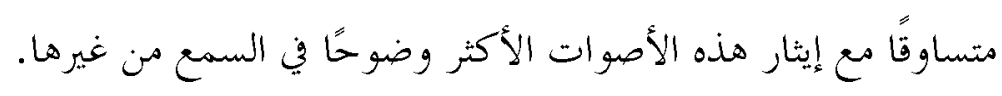

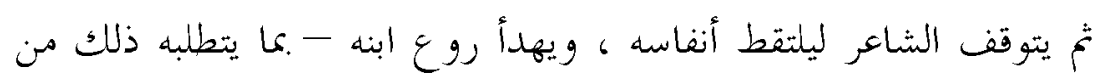

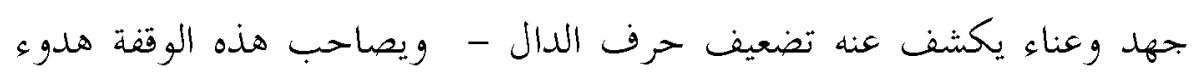

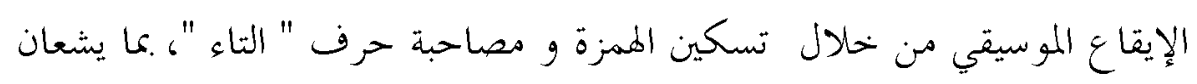




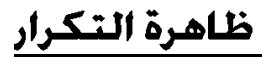

من أنغام هادئة ساكنة ، وعندها نصل إلى ما يشبه لحظة التنوير ، فتكون الإجابة " هذا حبيب الشعب في الأكفان ".

وقد يكون تكرار الحرف عن طريق تضعيفه ، فتضعيف صوت معين يزيد

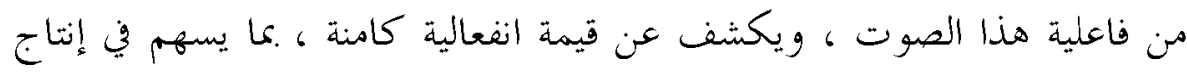
دلالة النص عن طريق التأكيد على هذه الظاهرة الصوتية .

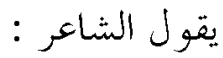

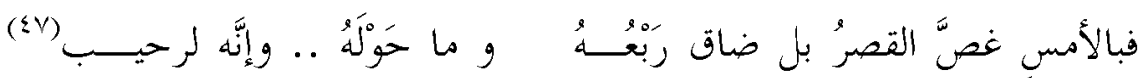

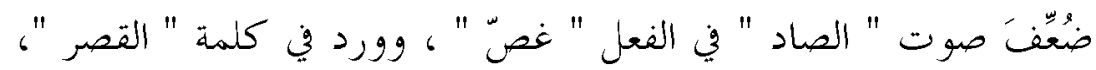
والصاد من أصوات "الصفير"(ي)") هذا التضعيف يشع في البيت قدرًا من التناغم

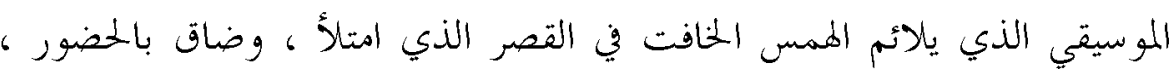

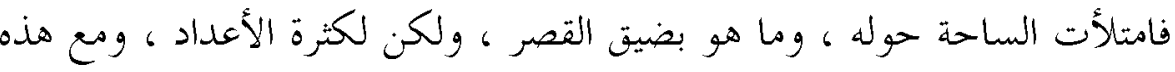

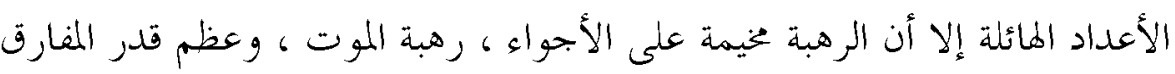

$\overline{3}$

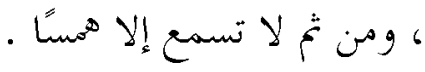

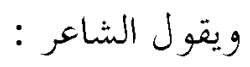

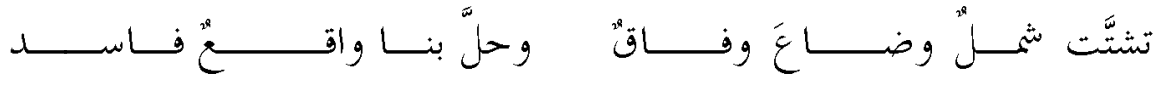

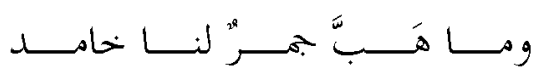

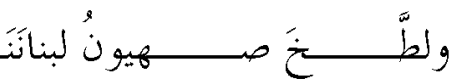

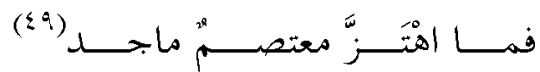

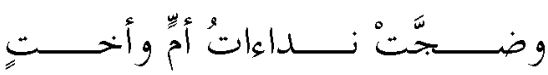
تكشف الأبيات عن قيمة انفعالية أثنارت وجدان الشاعر ، نلمح هذه القيمة

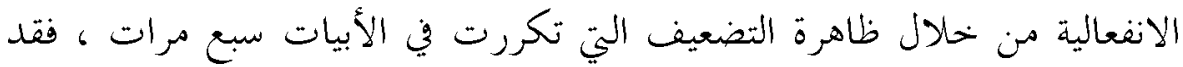

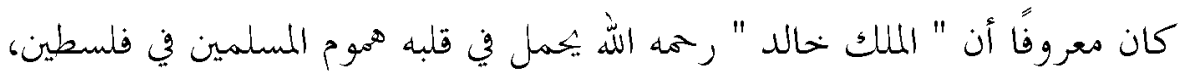

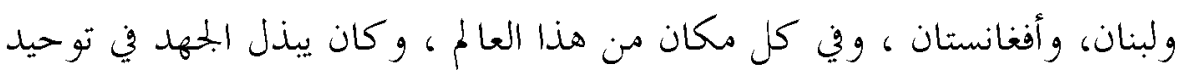

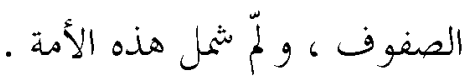




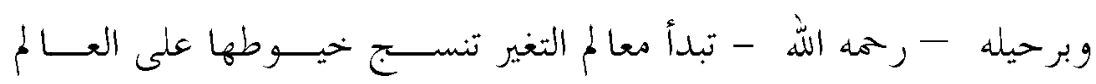
من خلال رؤية الشاعر ، فتتحول الوحدة إلى فرقة ، وقد ساعدت بنية التضعيف

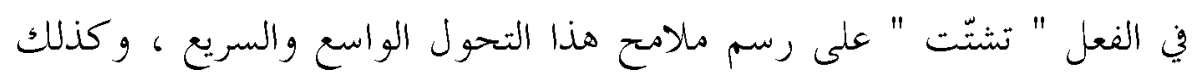
ساعدت بنية التضعيف في الفعل " حلّ " بتضعيف اللام - وهي من مل أكثر

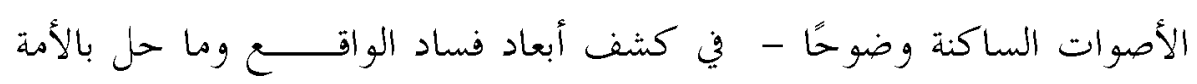

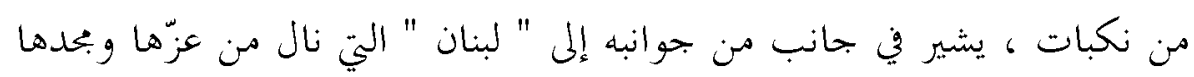

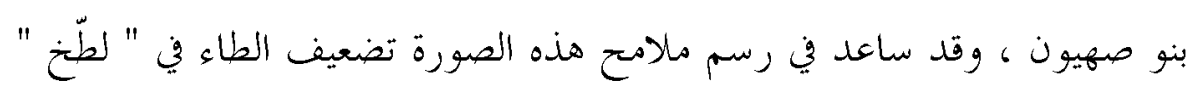

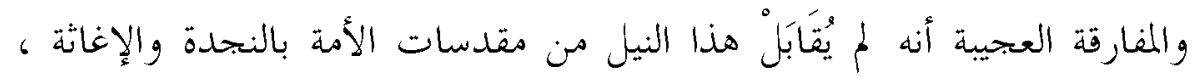

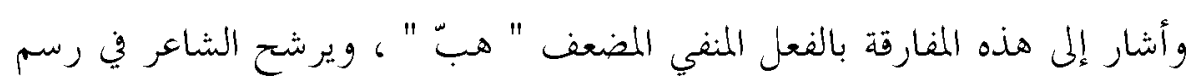

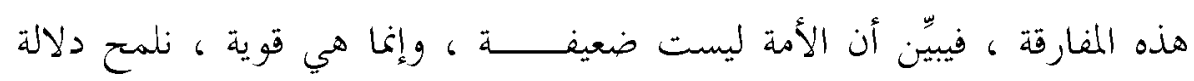

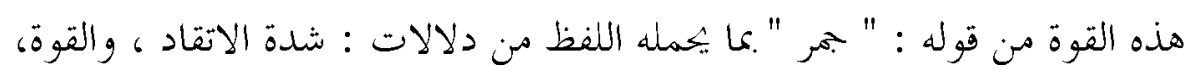

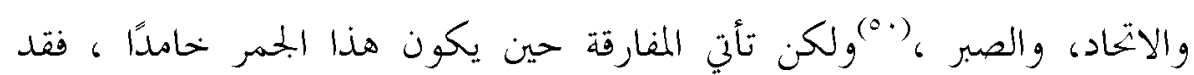
سُلب خاصيته . 101

ويستمر الشاعر في رسم ظلال هذه المفارقات ، حين تدوي في أرجاء

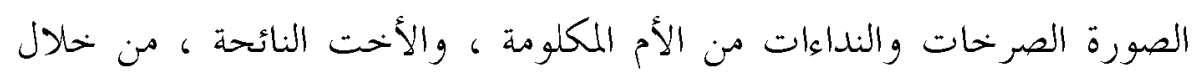
تضعيف صوت الجيم في " ضجّت "، فلا تجد هذه الصرخات من يسمع ويلبي ، وهنا استدعاء للمخزون التراثي التاريخي للخليفة العباسي المعتصم الذي سمع

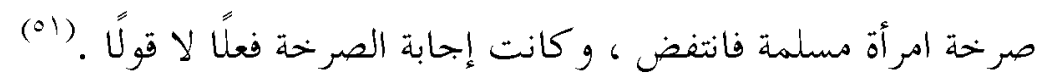
ويقول الشاعر :

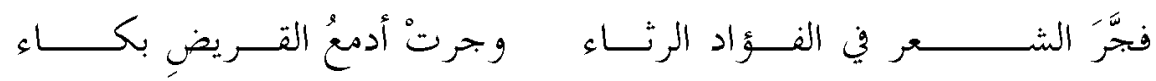
عرفنـــــاه

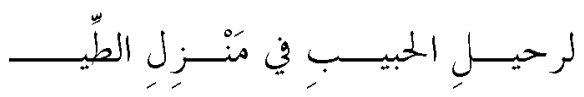

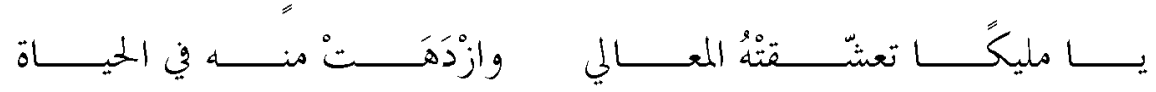
تنجح صورة الشاعر حينما يستطيع أن يضع حواس المتلقي على أبعاد هذه 


\section{طاهرة التكرار}

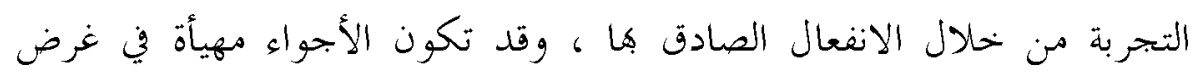

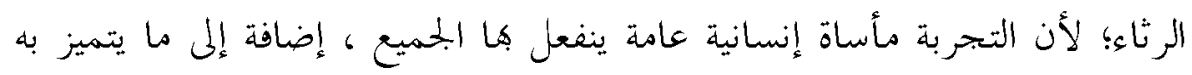

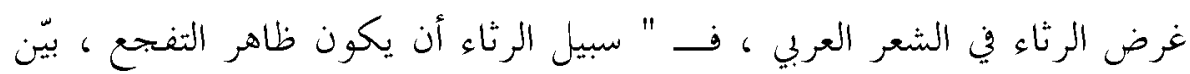

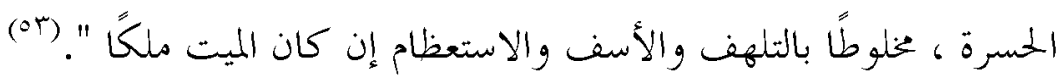

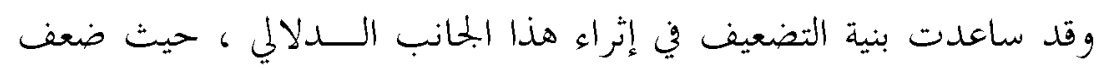

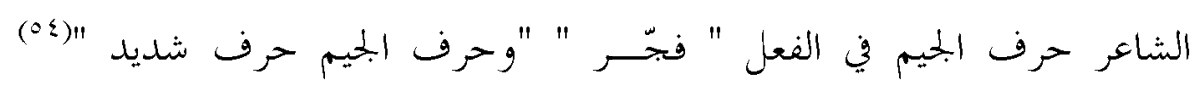

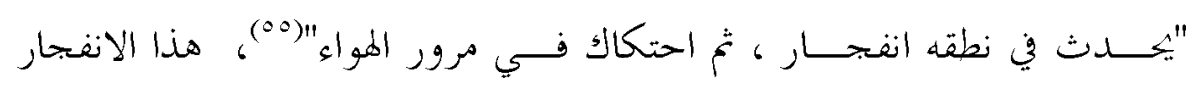

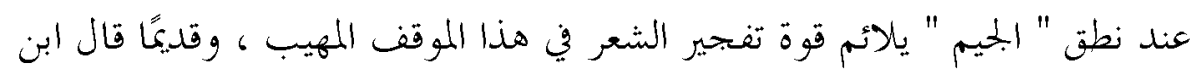

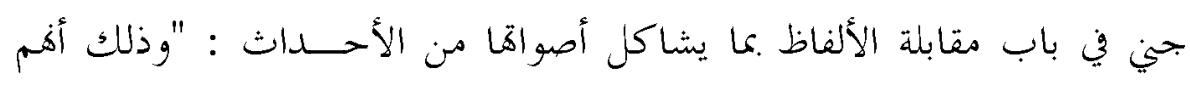

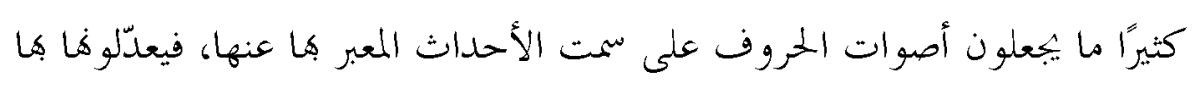

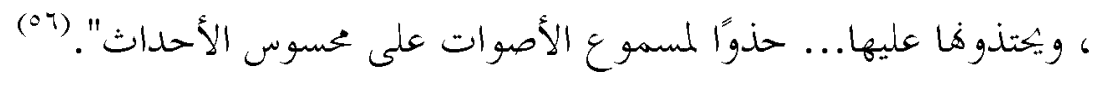

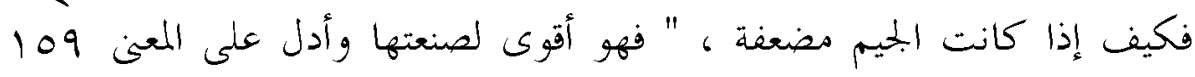

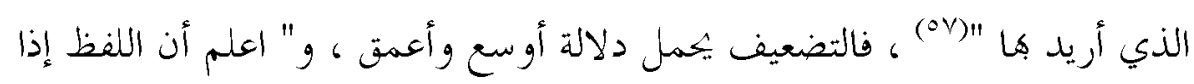

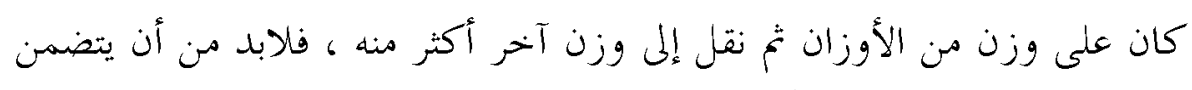

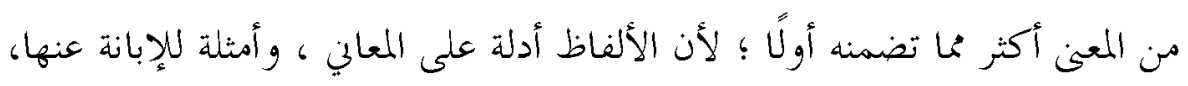

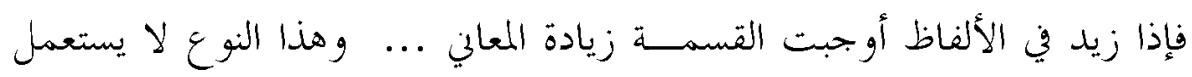

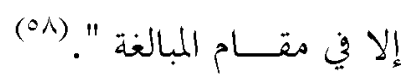

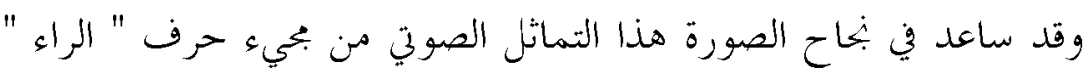

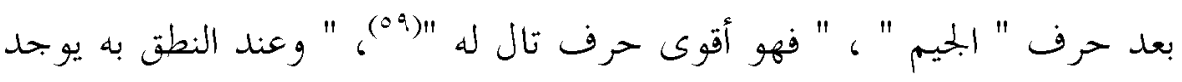

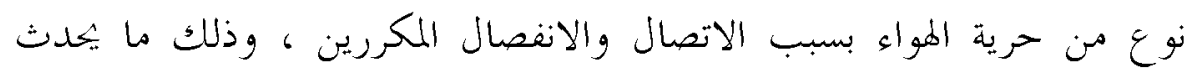

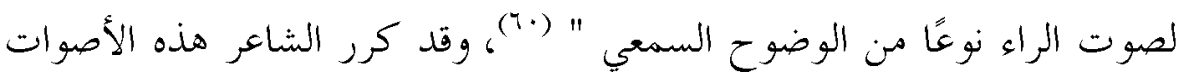

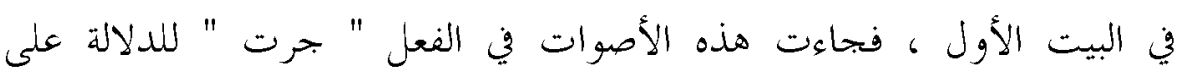

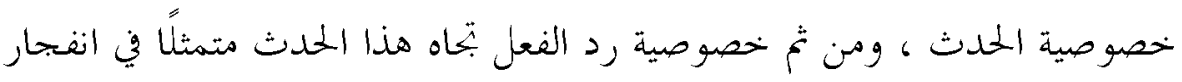

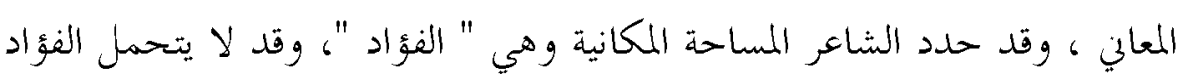




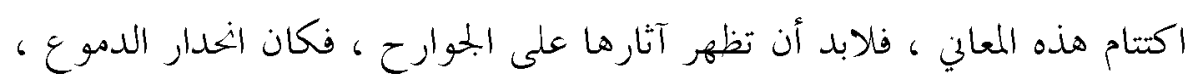

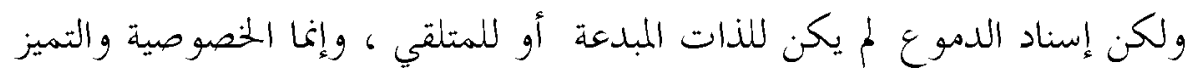
في هذه الصورة في إسناد الدموع إلى الشعر " أدمع القريض " وهن وهذا يعطي للمأساة

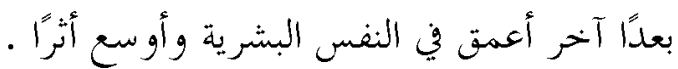

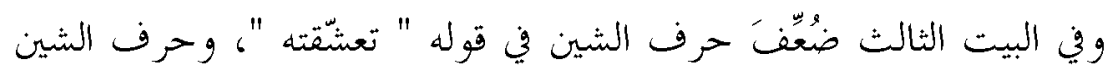
يتميز من بين صوامت العربية بالتفشي " وسبب تفشيها انتشار هوائها على دائرة

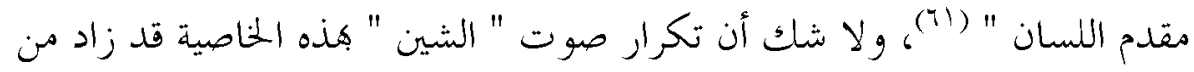
تنامي البنية الإيقاعية و تضافرها مع البنية الدلالية في تفخيم أمر المخبة التي وصلت إلى درجة العشق ، وقد ساعد في هذا الترابط بين البنية الإيقاعية والبنية الدلالية

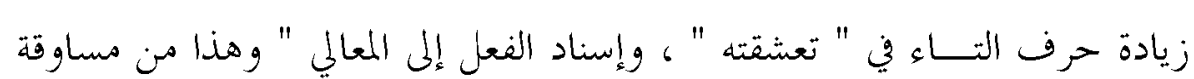

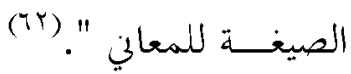

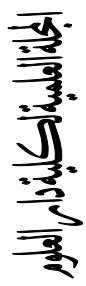

17. 


\section{ظاهرة التكرار}

\section{ا - القافية وخاصة التجانس الصوتي:}

قوام الشعر العربي وجوهره الوزن والقافيـة ، وللقافية دورها الوظيفي في

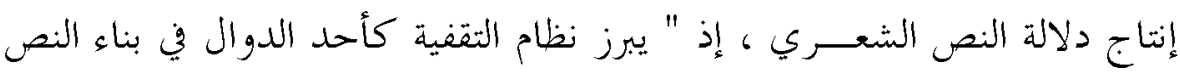
الشعري ، فلا تقتصر وظيفته على إحداث جرس صوتي متكرر في هاية البيت

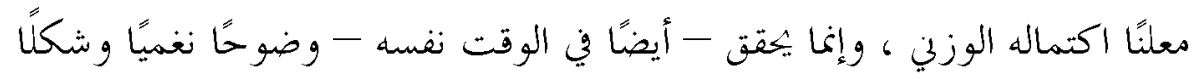

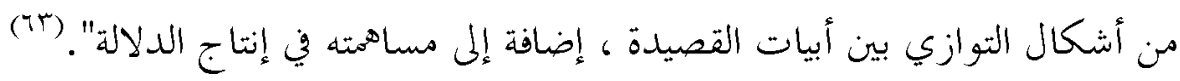

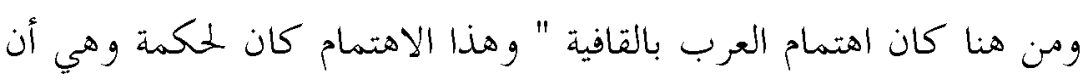

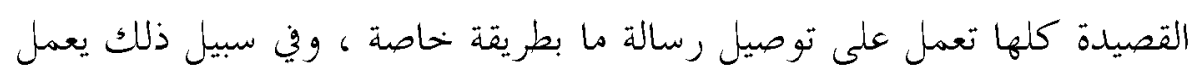

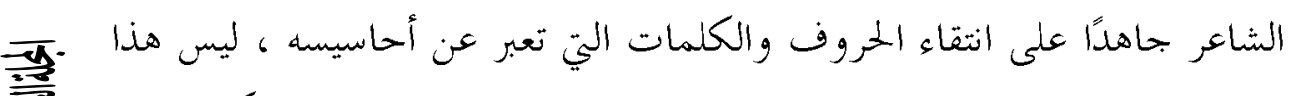

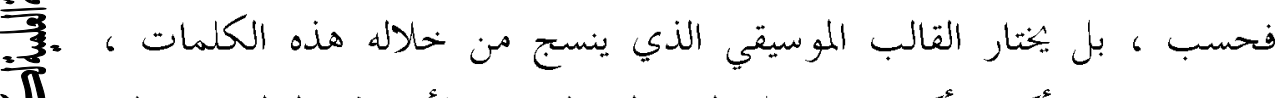

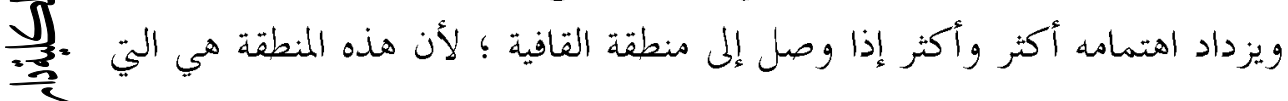

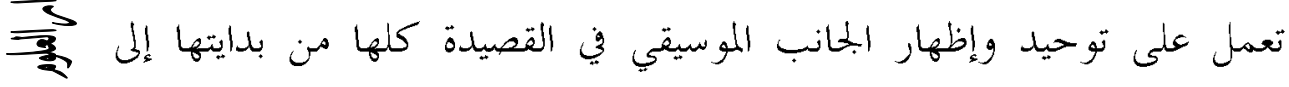
171

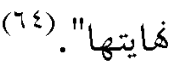

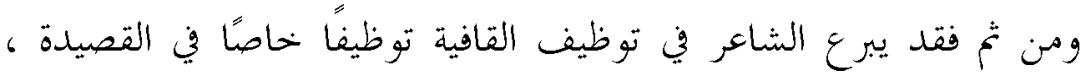

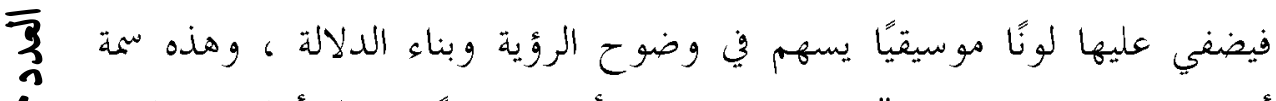

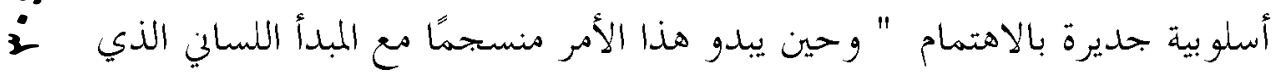

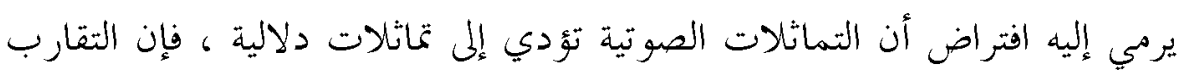

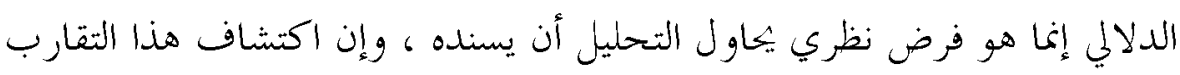

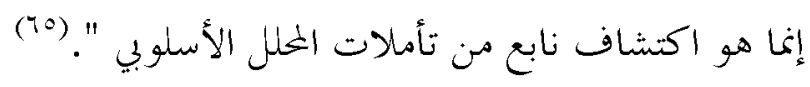
يقول الشناعر :

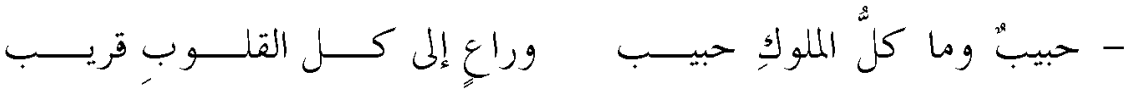

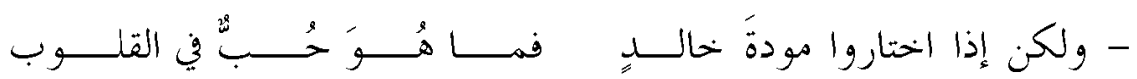

فقد حافظ الشاعر على الجلذر الصوتي لكلمات القافية ؛ مُا أحدث توازنًا

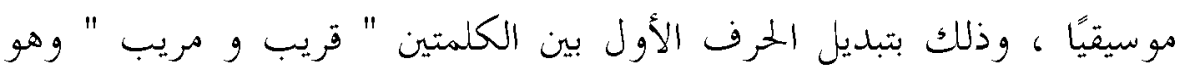

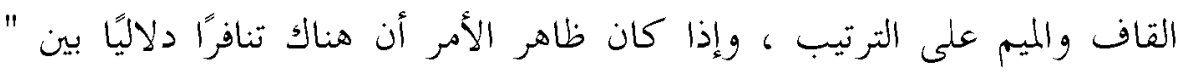


قريب " و " مريب " إلا أنه في إطار السياق الدلالي في البيت الأول إثبات القرب

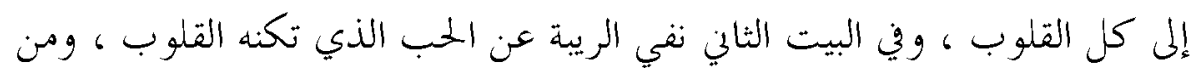
تم نلمح التجانس بين البنية الإيقاعية والبنية الدلالية .

$$
\text { ويقول الشاعر : }
$$

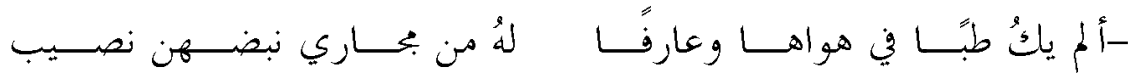

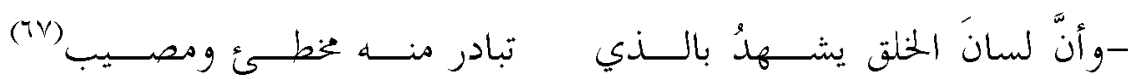
فقد أبقى الشاعر أيضًا على الجذر الصوتي لكلمات القافية ؛ منا حافظ على

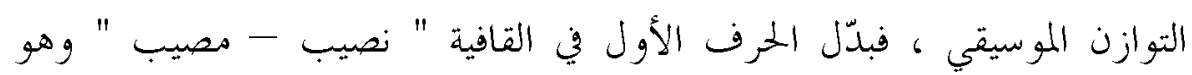
"النون " و " الميم " ، وبالنظر إلى التمثيل الدلالي الذي ينبثق من اللفظين نلمح

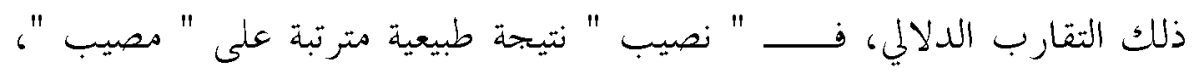
وكلاما يشير بصورة واضحة إلى النجاح والتوفيق .

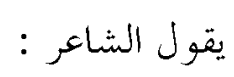

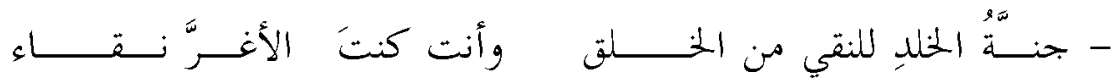

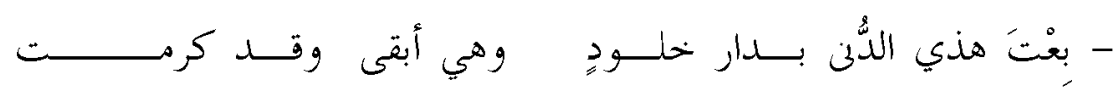

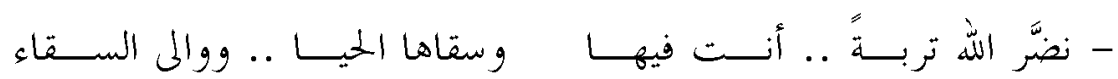
استطاع الشاعر في هذه الأبيات أن بحافظ على الجذر الصوتي في القافية ،

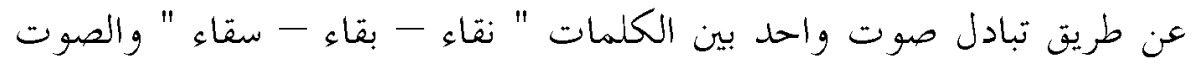

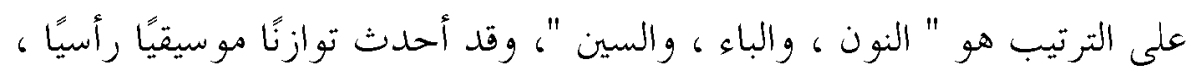

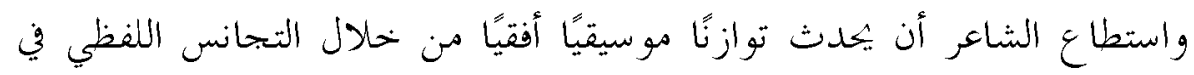

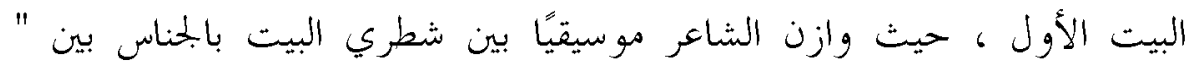

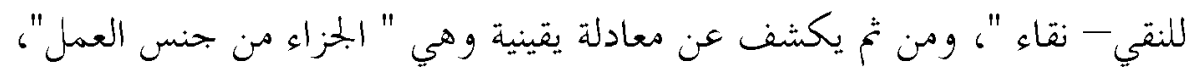

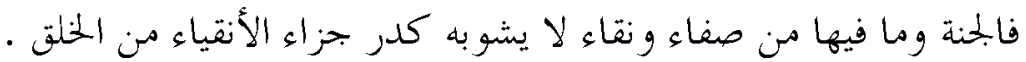

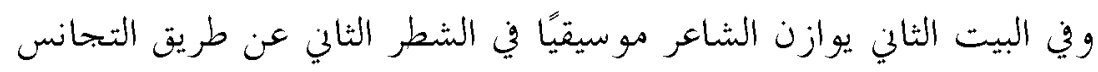

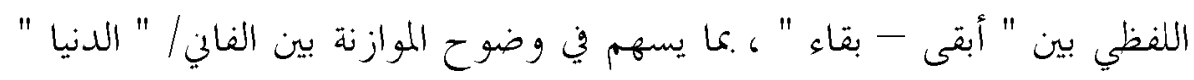




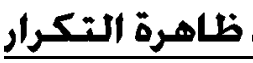

$$
\text { والباقي /" الآخرة " في صورة واضحة أقرب إلى ذهن المثلقي. }
$$

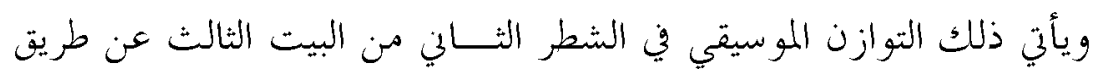

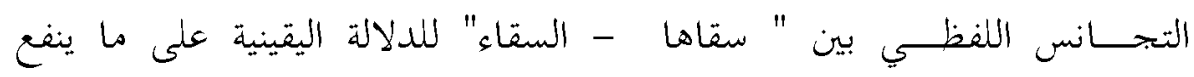

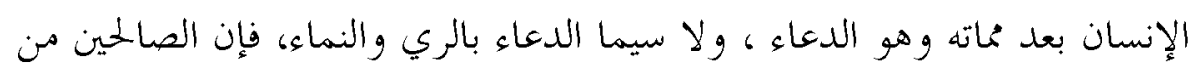

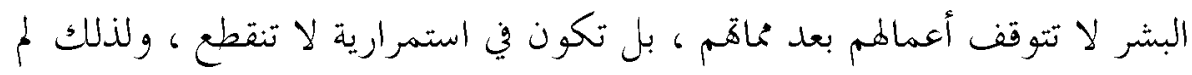

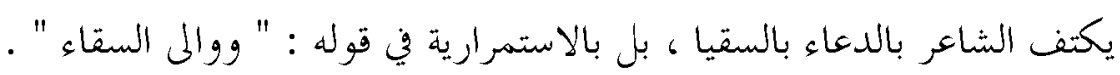
وعلى صعيد آخر بند ذلك الترابط الدلالي بين كلمات القافية : " نقاء -

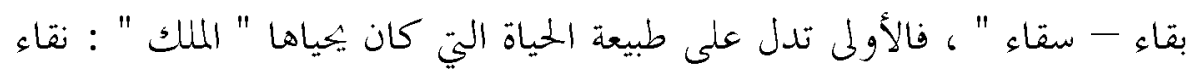

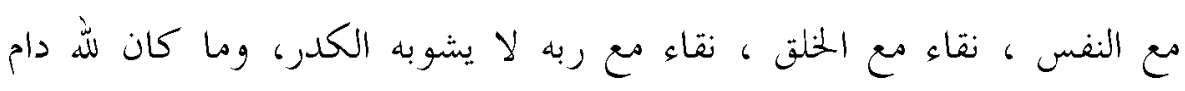

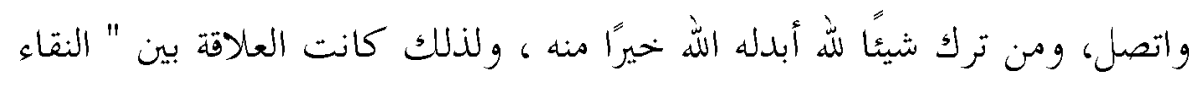

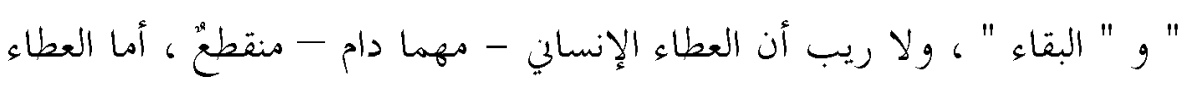

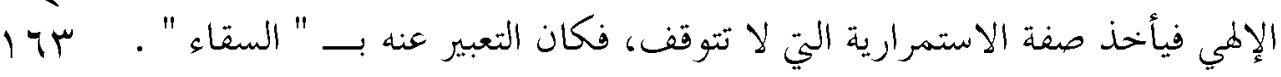

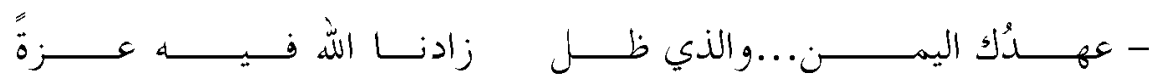

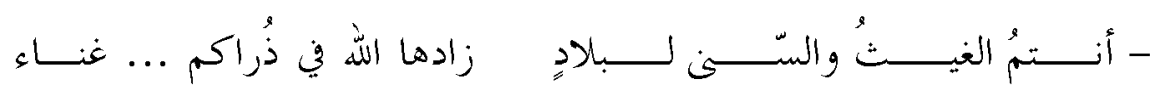

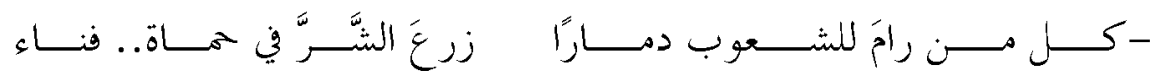

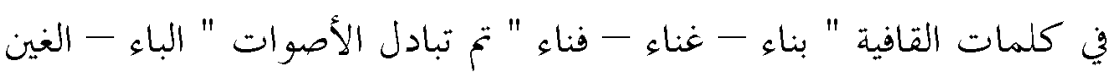

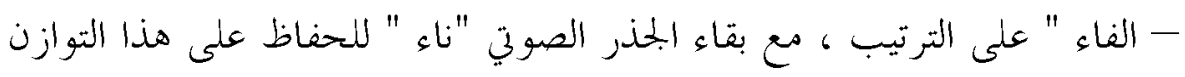

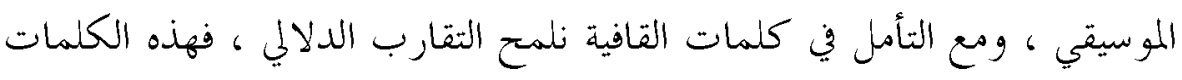

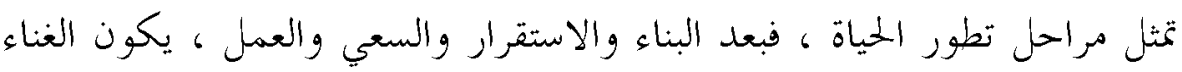

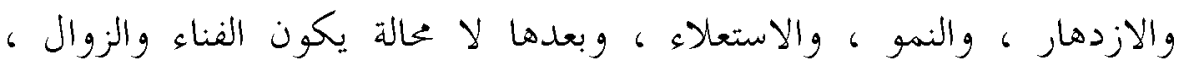

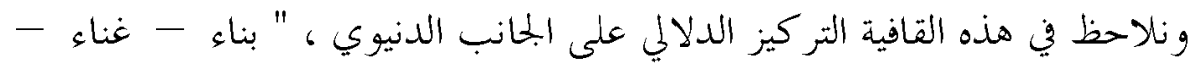

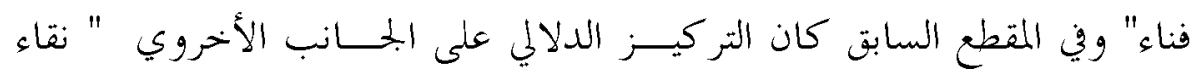

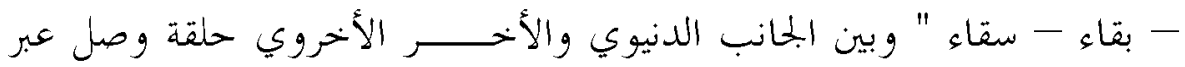


عنها الشاعر في قوله :

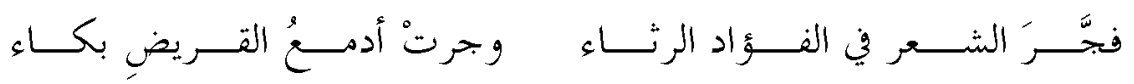

فالبكاء هو الرابط الدلالي بين مرحلة الدنيا وفراقها ، و التحول عنها إلى

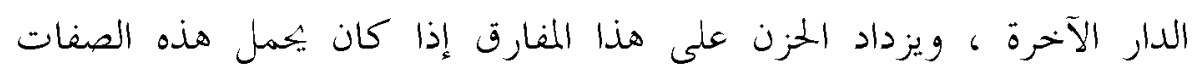

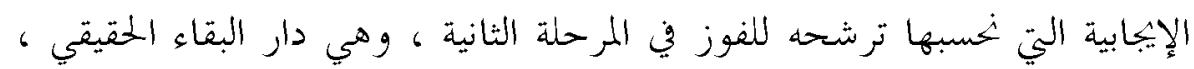
ومن ثم يكون الترتيب الدلالي على هذا النحو :

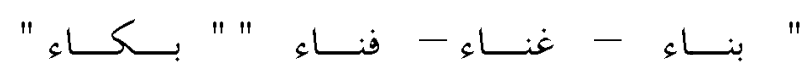

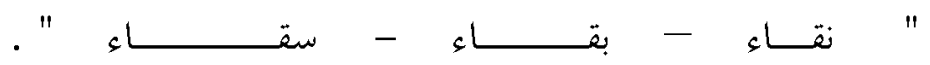

ومن ثخ كانت كلمة القافية " بكاء " هي الرابط الدلالي بين المرحلتين ، ووع

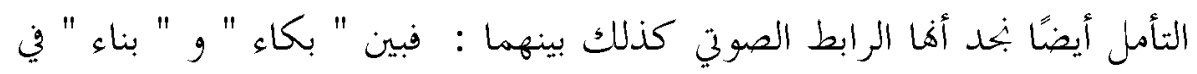
مرحلة التطور الدنيوي توازن صوتي من خلال التبادل بين صوتي " الكاف ،

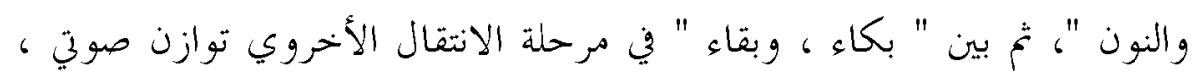

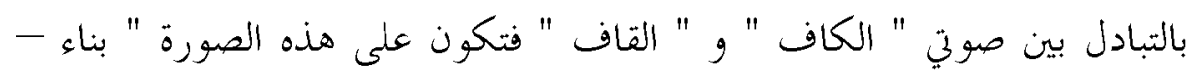

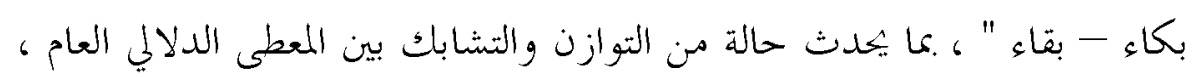
والتمثيل الصوتي في الكلمات التي نتجت عنها التمثيلات الدلالية .

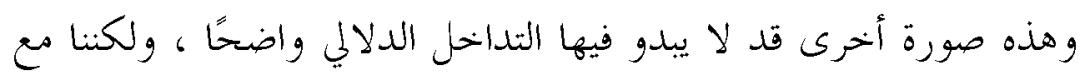

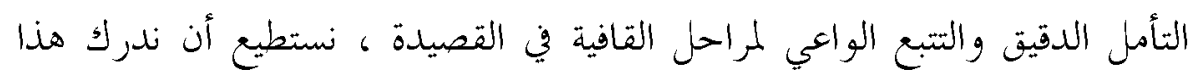
التداخل الواضح بين البنية الدلالية والبنية الإيقاعية ، يمثل هذه الصورة فصيدة

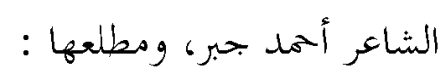

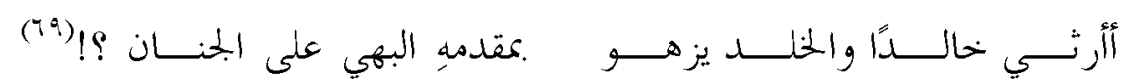
فقد جاءت القوافي في ثلاث بحموعات صوتية ، وهي كالتالي :

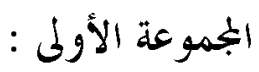

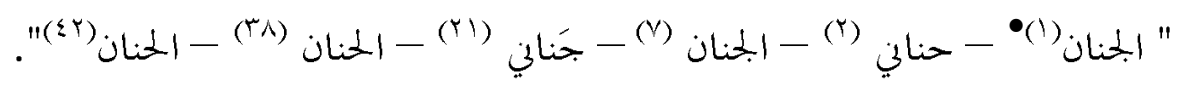




\section{ظـاهرة التكرار}

يبدو في هذه المرحلة اهتمام الشاعر بالجانب الإيقاعي من خلال تكرار

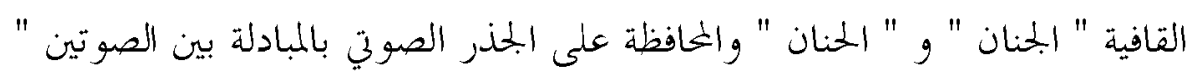

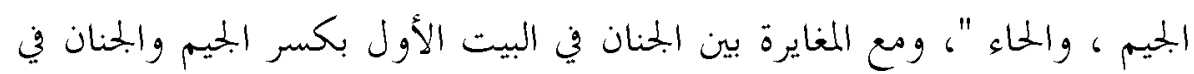
البيت الحلادي والعشرين بفتح الجيم ، إلا أن الكلمات جميعها نسير في إطار دلالي واحد ، وهو انشغال الفكر والوجدان ، وصدق العاطفة نغو هذا الخبيب المفارق ، ومن ثم الانشغال بالدعاء له أن ينعم في الجنان .

\section{الجمموعة الثانية : الثمان}

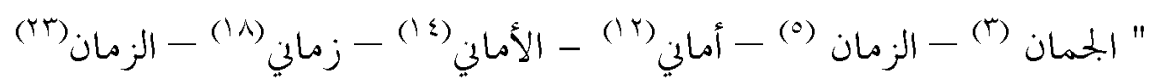

$$
\begin{aligned}
& \text { - الزمان (r.) }
\end{aligned}
$$

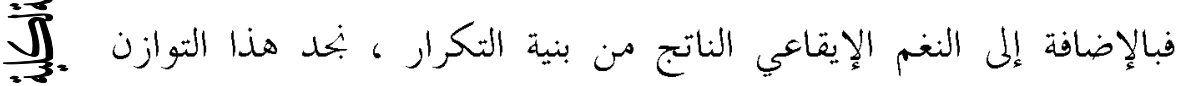

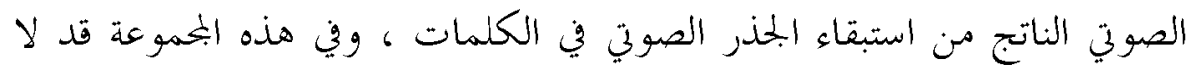

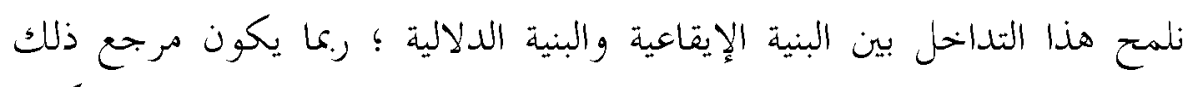

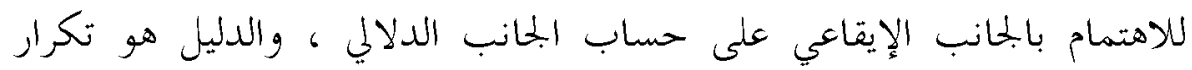

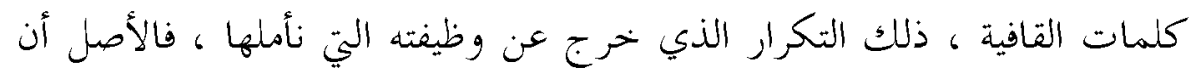

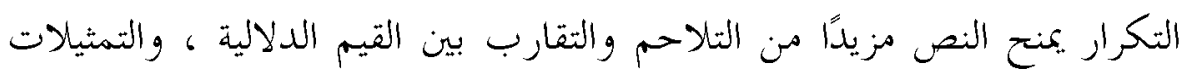

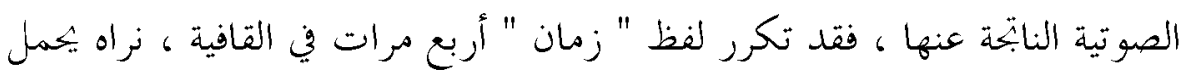

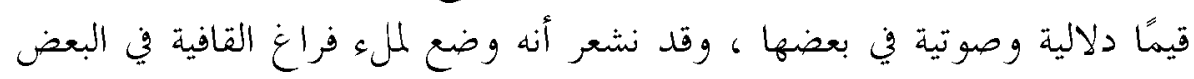

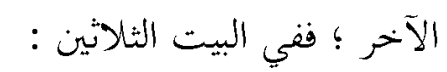

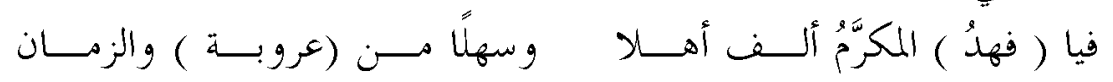

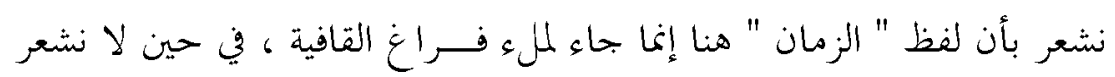

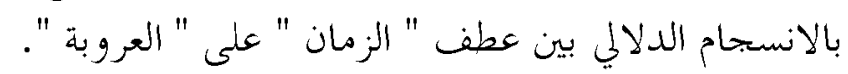

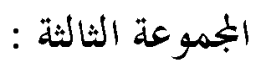

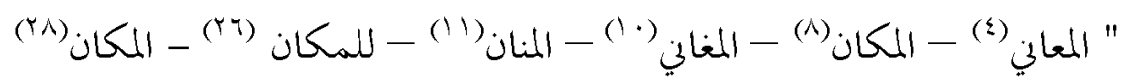

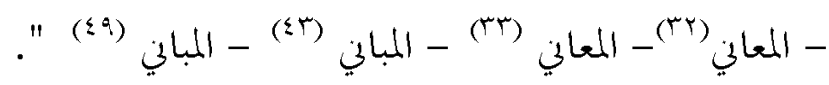

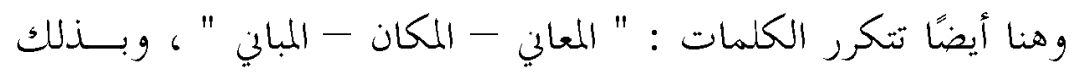


تصبح كلمات هذه المخموعة هي : " المعاني - المكان - المغاني - المنان - المباني " وفيها استباء للجذر الصوتي مع الحفاظ على التوازن الموسيقي من خحلال تبادل الحـــروف " العين - الكاف - الغين - النون - الباء " على الترنيب .

وتستوقفني هنا الملاحظة السابقة نفسها ، وهي عدم الانسجام في تكرار

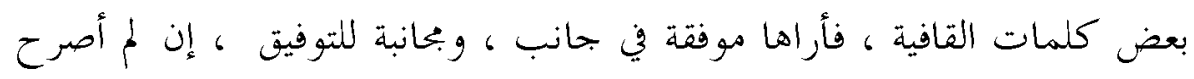

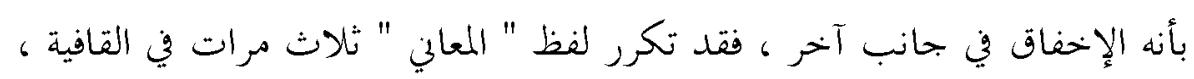
ولعلك تشعر معي بعدم الانسجام في البيتين الثاني والثلاثين ، و الثالث والثلاثين حيث يقول :

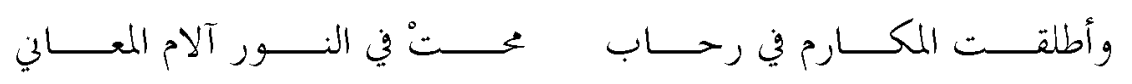

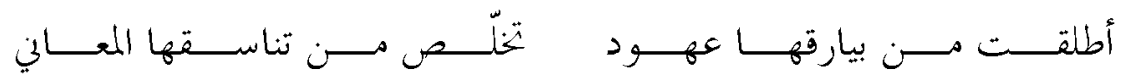
ولعلي ألتمس العذر لشاعرنا حينما ندرك أثر العامل النفسي ، وما بمكن أن يحدثه من تفاعل في الدلالة وإعادة تشكيل العناصر ، خاصة أنه ينتقل في القصيدة

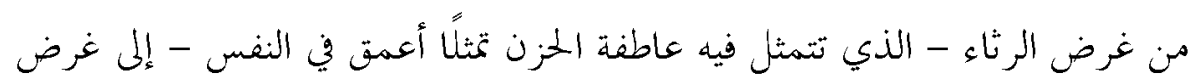

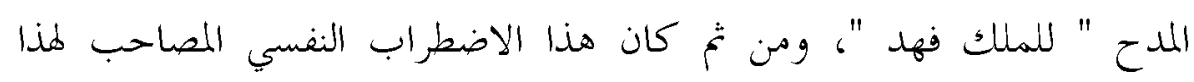
الانتقال، فظهر هذا القلق وعدم الانسجام في القافية . ومع إعادة النظر في هذه البمموعات الصوتية التي تمثلها مراحل القافية في

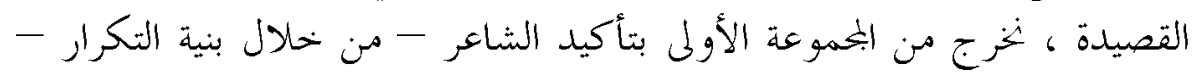

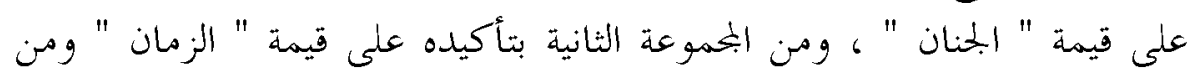

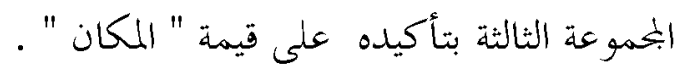

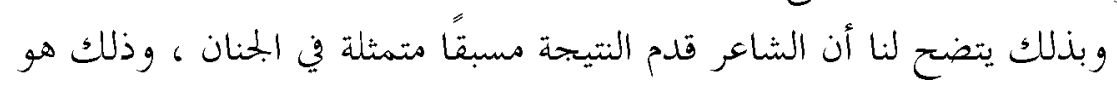
الجزاء الطبيعي لهذه المعادلة، فمن جمع بين فضل الزمان وشرفه ، وأحسن استغلاله،

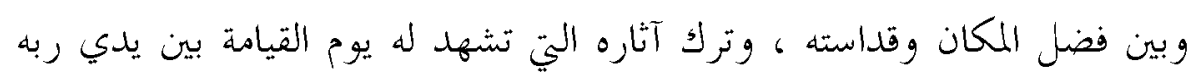
سبحانه وتعالى ، فإن الجزاء الطبيعي هو الفوز هذذه " الجنان". 


\section{ظاهرة التكرار}

\section{:}

يلجأ الشعراء في تشكيل الإيقاع الموسيقي إلى التوحيد بين العروض

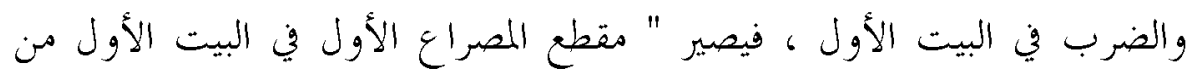

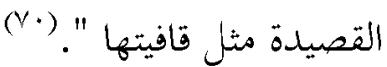

وبمثل التصريع قيمة موسيقية فاعلة في تشكيل الرؤية وبناء الدلالة " وإنما

يذهب الشعراء المطبوعون البخيدون إلى ذلك ؛ لأن بنية الشعر إنما هي التسجيع

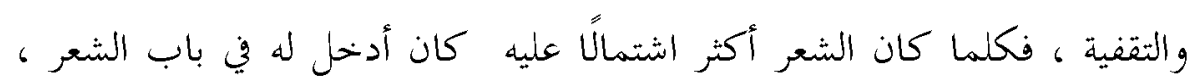
وأخرج له عن مذهب النثر ". (VI)

ولا يقف دور التصريع عند مهارة المبدع وحسن إجادته ، وتحديد القافية

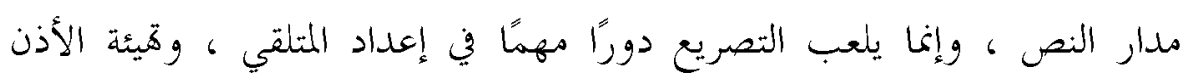

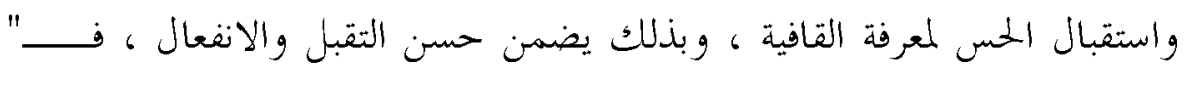

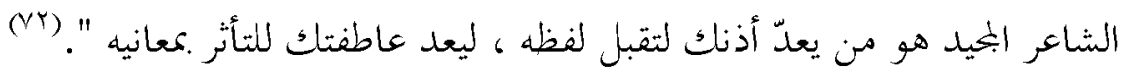

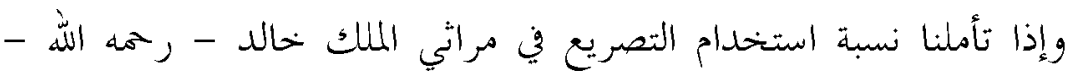
وجدنا سبعًا وعشرين "YV " قصيدة قد افتتحت بالتصريع من إجمالي قصائد

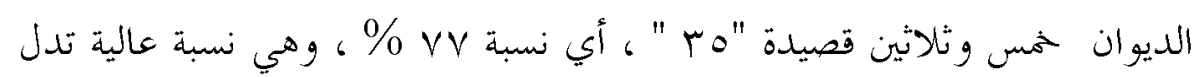
على أن قيمة التصريع من القيم الدالة في تشكيل الإيقاع الموسيقي ، وأها ذات

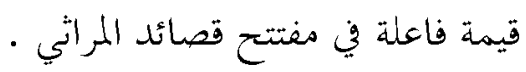

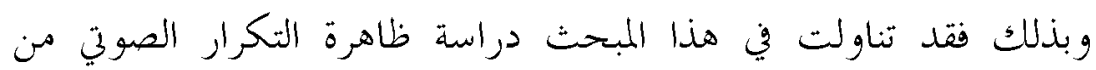

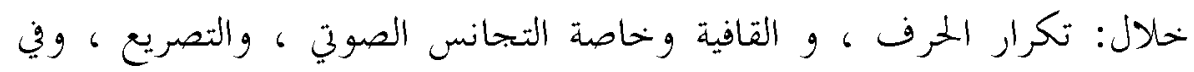
المبحث التالي سألقي الضوء على التكرار اللفظي .

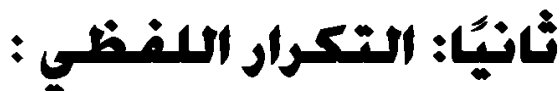

يقوم التكرار اللفظي في " مراثي الملك خالد " على اختيار بنيات أسلو بية 
بعينها ، وتوظيفها في السياق الشعري ، حاملة دلالات قوية ومثيرة ، فإذا به يضيء لنا نفسية الشاعر في التركيز على هذا النمط الأسلوبي ، فنطلع على جانب خغي آثار انفعال الشاعر ، من خحلال التركيز على هذه البنيات الأسلوبية ، و كذلك يؤدي وظيفة أخرى لدى المتلقي ، إذ يعمل على إثارة انتباهه وجذب لئب

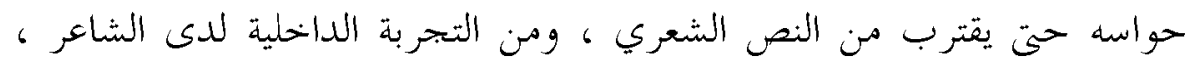
فينفعل هو الآخر هذذه التجربة، وبذلك فإنه يكمل في ثناياه دلالات نفسية وانفعالية ينقل من خحلالما المتلقي إلى أجواء الشاعر الداخلية . كذلك نراه أداة جمالية تضفي على النص الشعري الانسجام والتلاحم التما

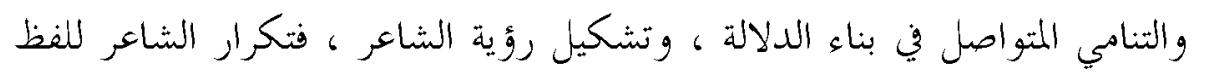

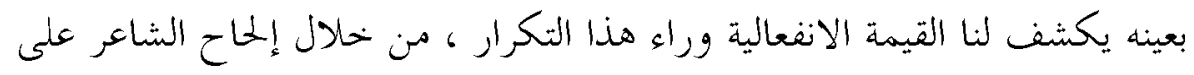

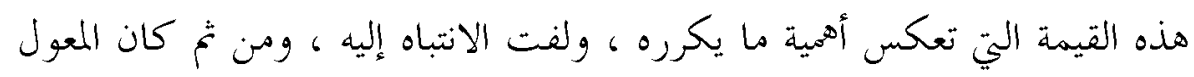

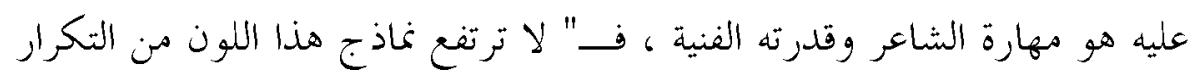

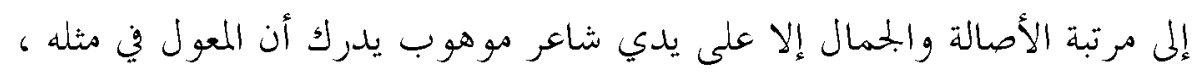

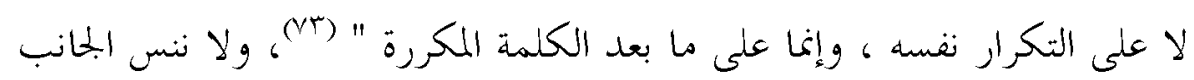

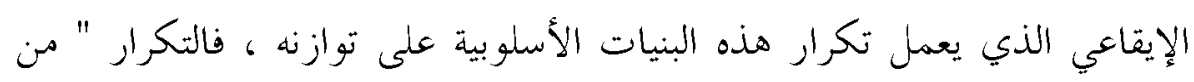

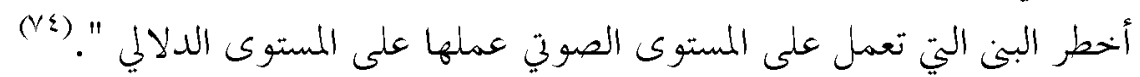

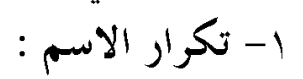

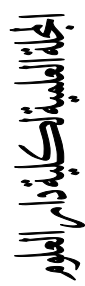

171

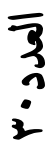

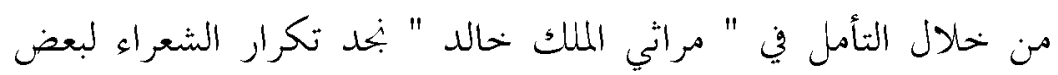

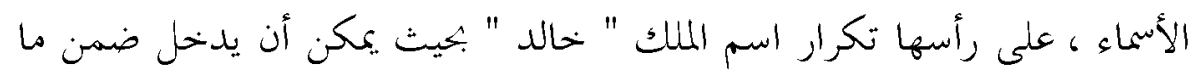

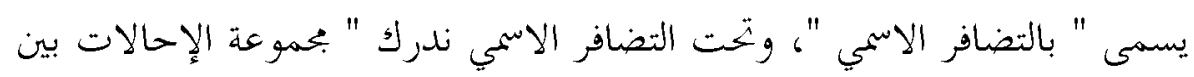

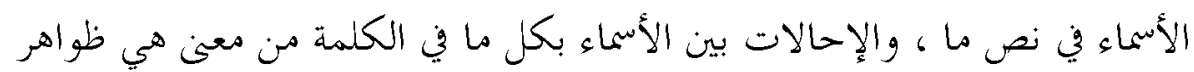

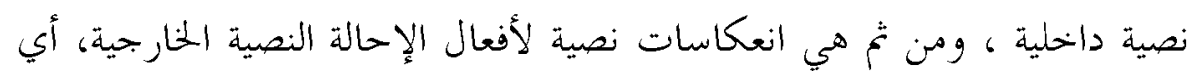

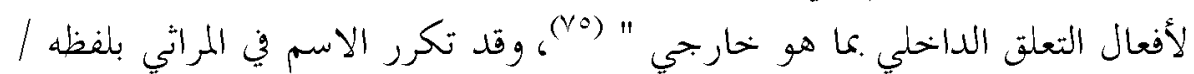

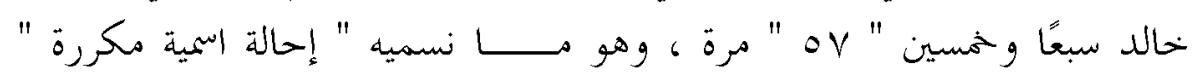

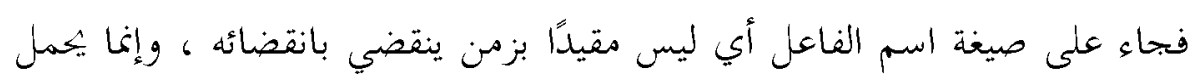




\section{ظكاهرة التكرار}

دلالة الاستمرارية والتواصل والخلود ، فإذا به يممل دلالات مكثفة ، وقيمًا روحية

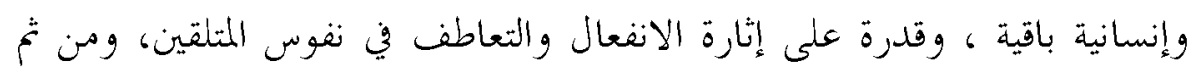

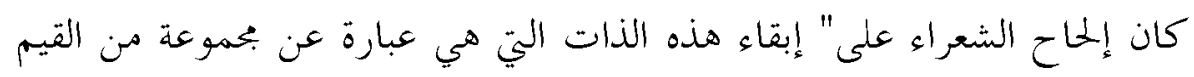

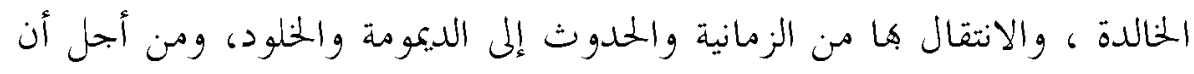

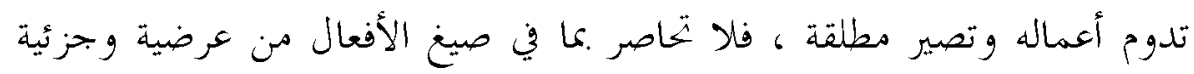

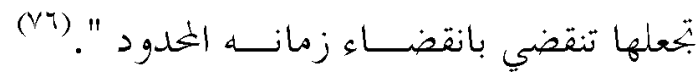

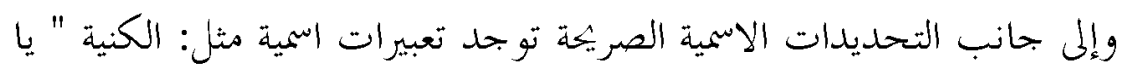

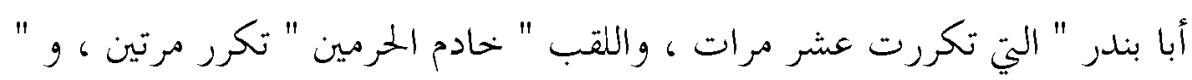
خادم البيت " مرة واحدة ، و كذلك قد تنوب بعض التعبيرات الوصفية لتحل محل

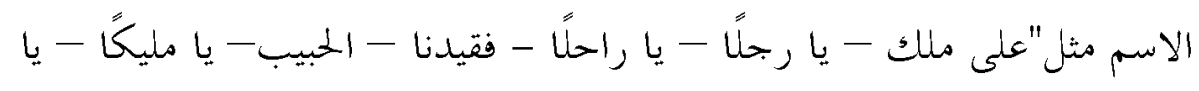

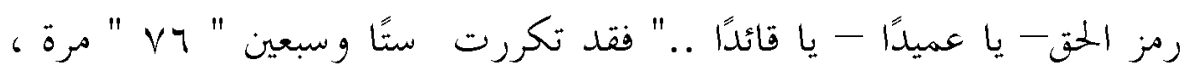
وهي جميعًا إحالات في صورة إعادة للصياغة.

من خحلال هذا الإحصاء نستطيع أن ندرك بوضوح هذا الحضور المؤثر " 179

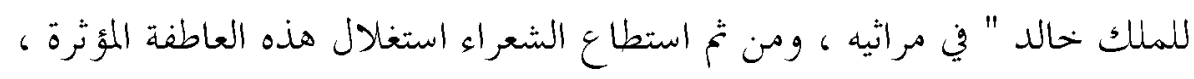

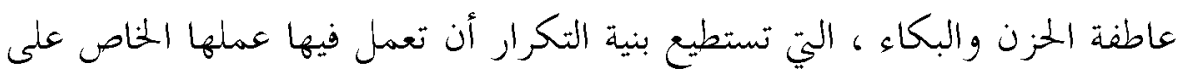

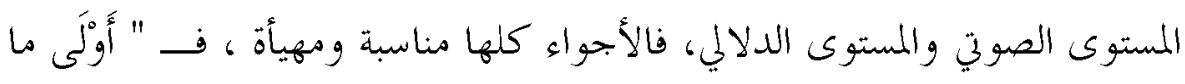
تكرر فيه الكالام باب الرثاء؛ لمكان الفجيعة، وشدة القرحة التي يجدها (v)

ومن نماذج تكرار اسم "الملك خالد " قول الشاعر محمد بن عبد الله المعلمي:

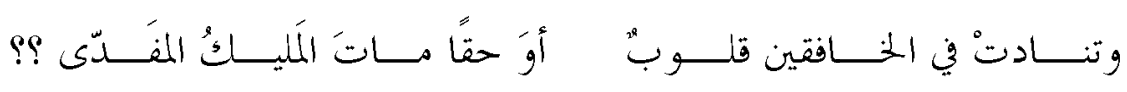

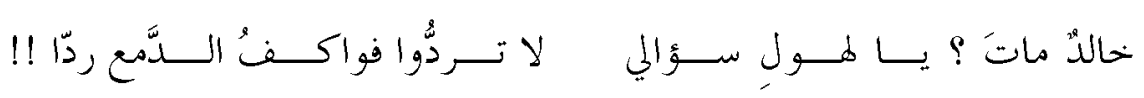

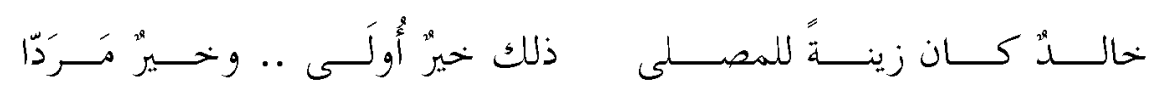

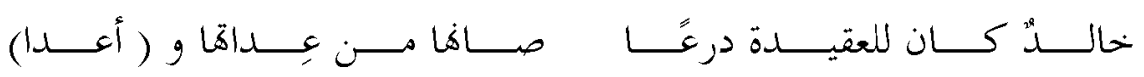




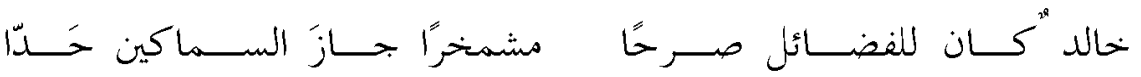

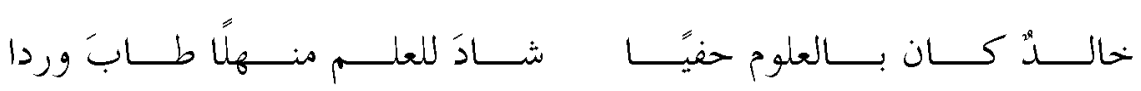

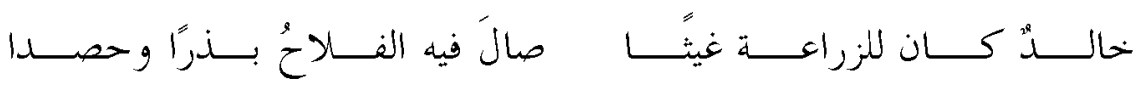

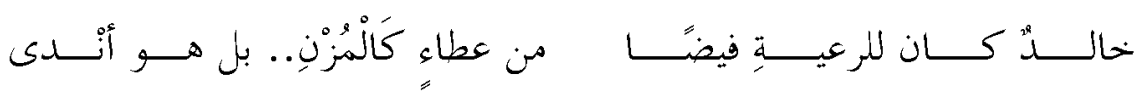

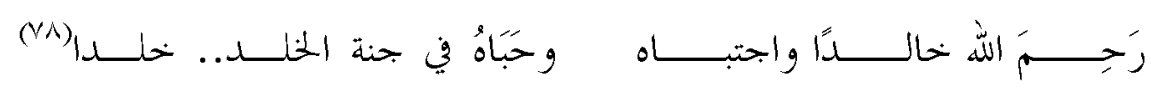
تبدأ الأبيات هذا الاستفهام الذي يممل دلالة الحسرة والتفجع ، فالشاعر لا

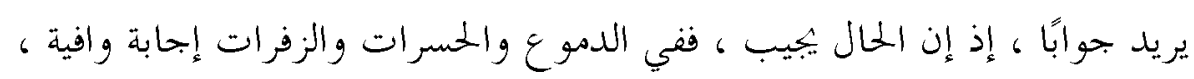

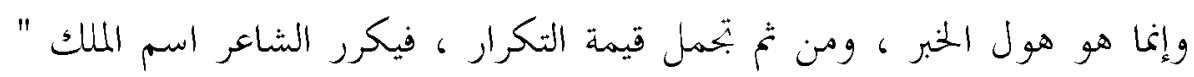

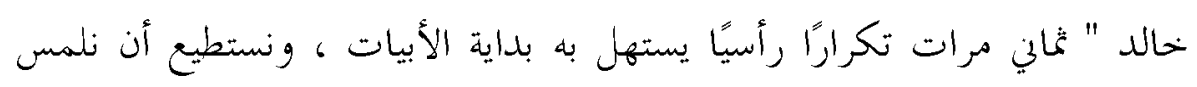

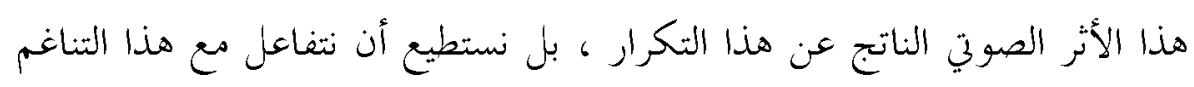

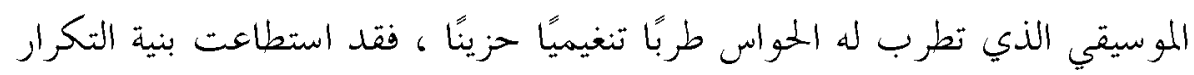

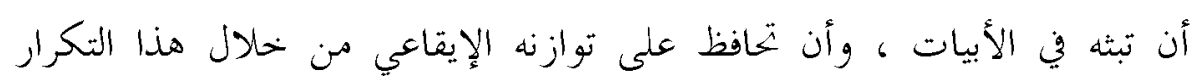

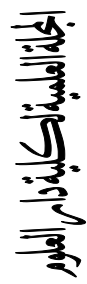

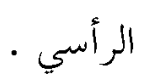

وتكرار الاسم في هذه الأبيات يممل في ثناياه دلالات نفسية وانفعالية ، فالشاعر يريد أن يجذب انتبــاه المتلقي ليشاركه هذه التجربة ، فاستفتح قصيدته

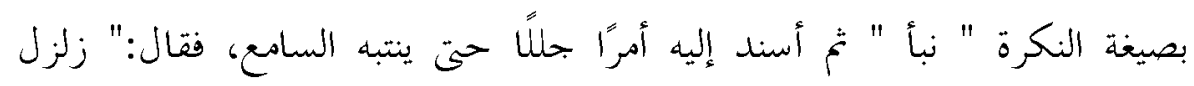

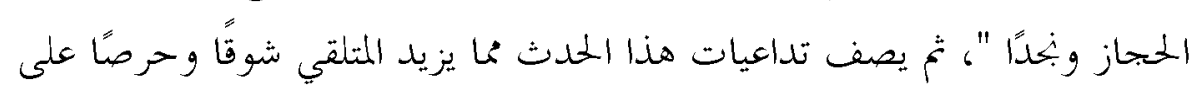

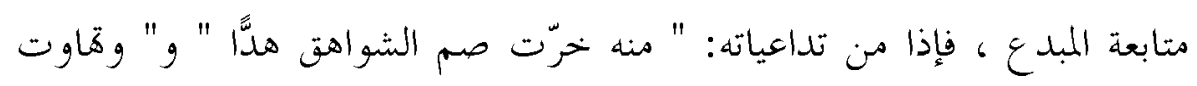

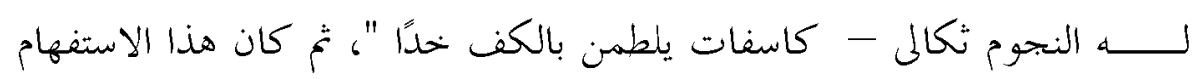

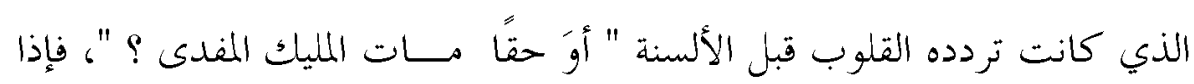
ما كانت هذه المشاركة المؤثرة من الظواهر الطبيعية في الكون من جبال وبنوم ،

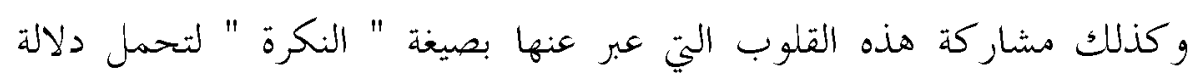




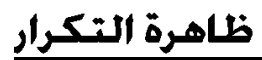

الشمول ، وإذا كان هذا الانغعال الواضح الحزين من الشاعر ، فأين المتلقي

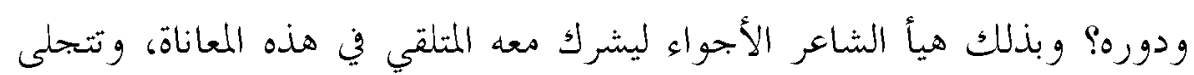

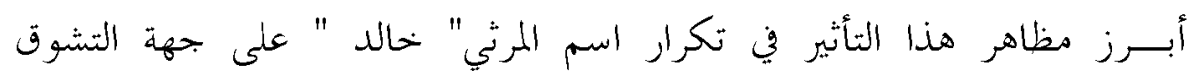

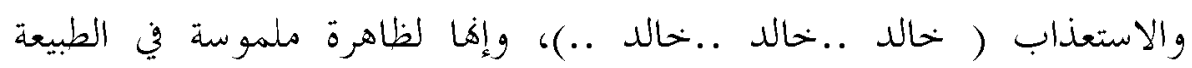

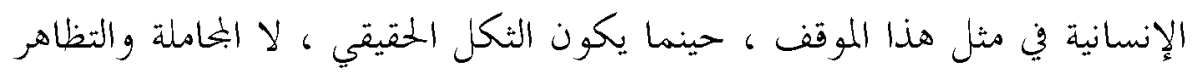

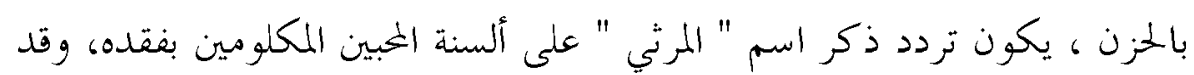

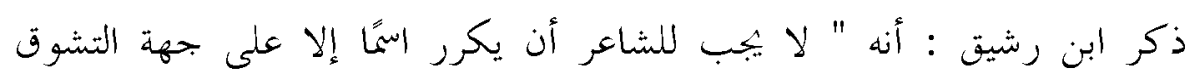

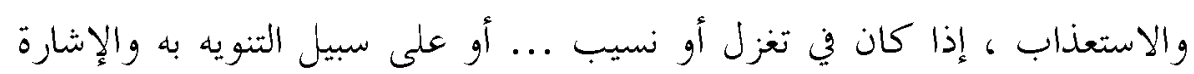

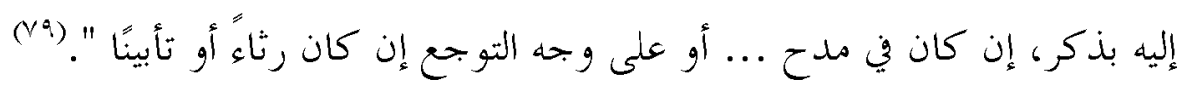

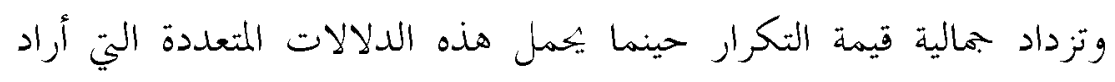

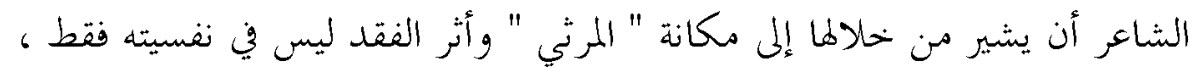

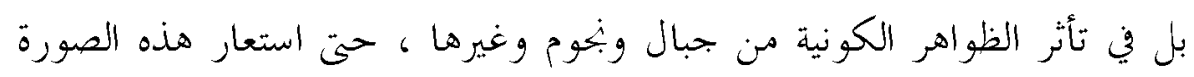

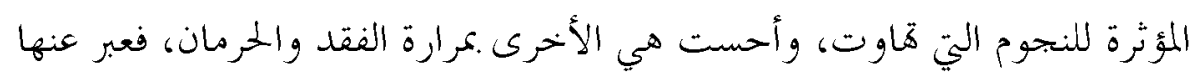

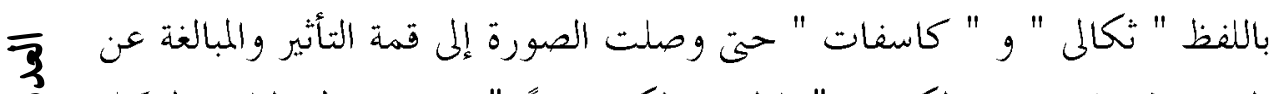

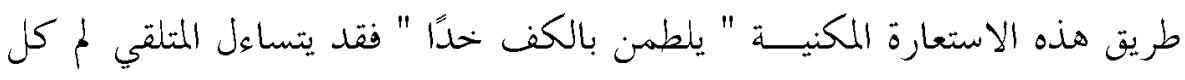

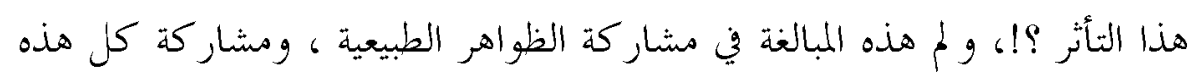

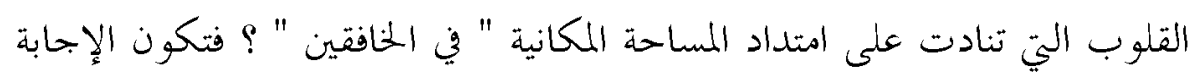

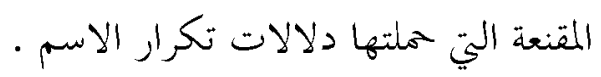

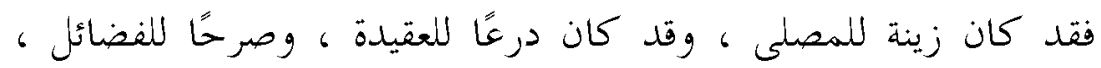

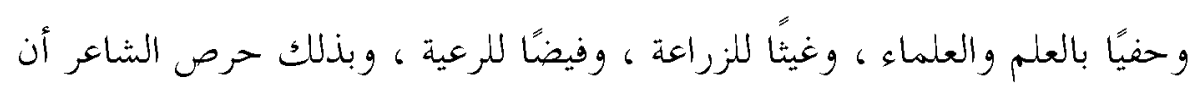

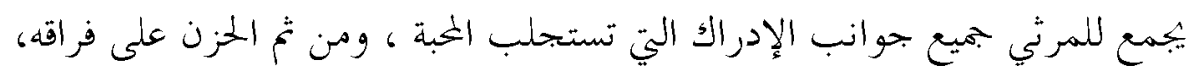

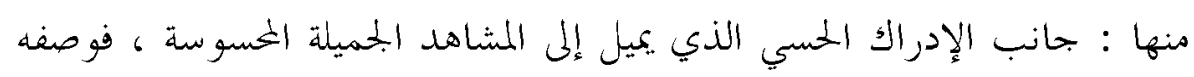

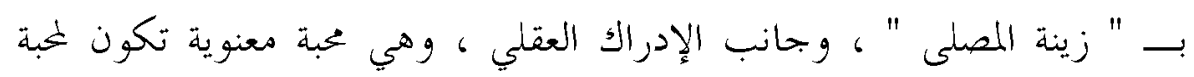

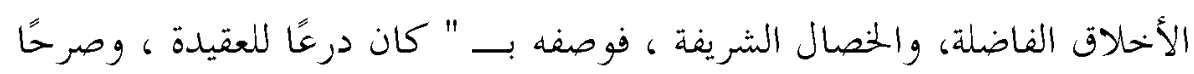


للفضائل ، وحفيًا بالعلم والعلماء " ، وهناك جانب آنر من جن جوانب الخبة وهي

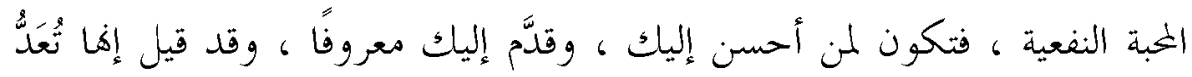
نوعًا من الحمد والشكر ، فوصفه بـــ " الفيض للرعية " وصوز عطاءه بالمزن الذي إيل يكمل النفع لمن يستحق ولمن لا يستحق ، فالكل ينهل من خيره وجوده ، وقد

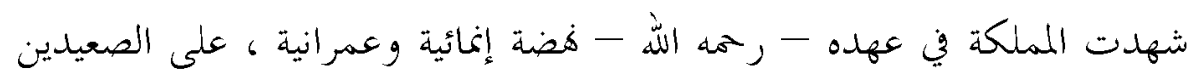

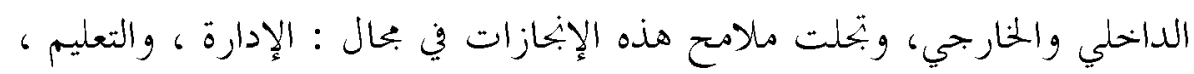

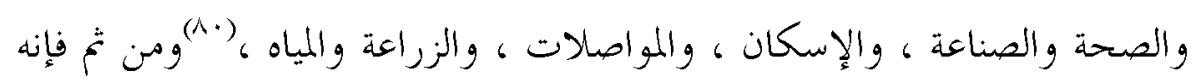

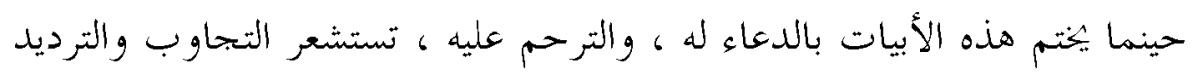

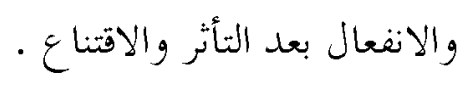

$$
\text { ويقول الشاعر : }
$$

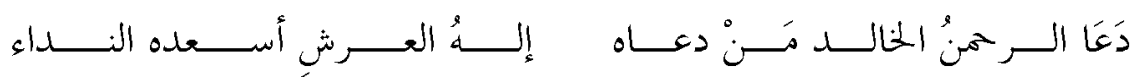

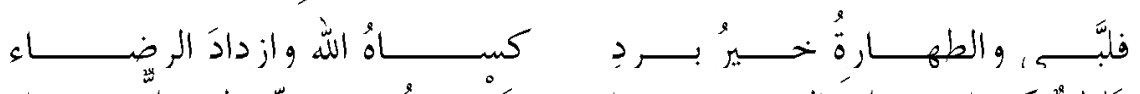

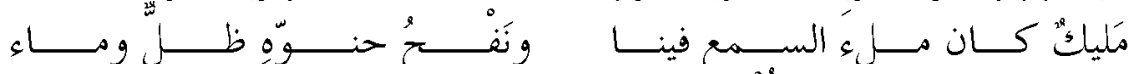

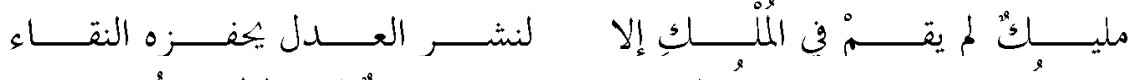

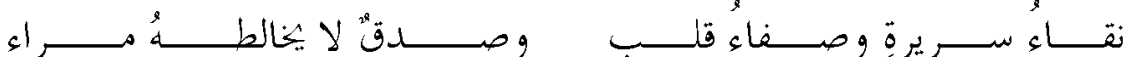

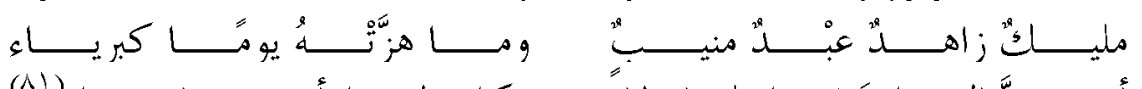

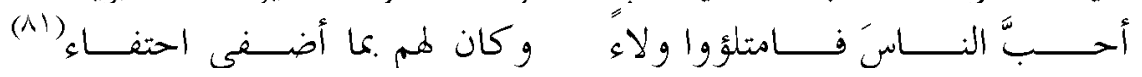

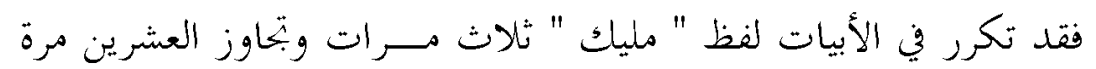

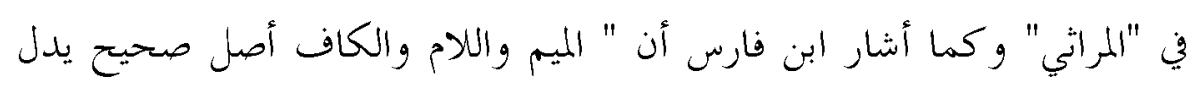

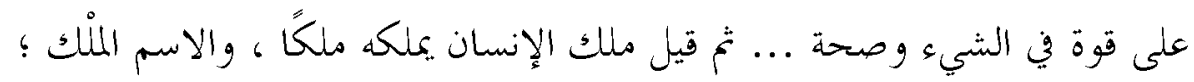
لأن يلده فيه قوية صحيحة ". (Ar)

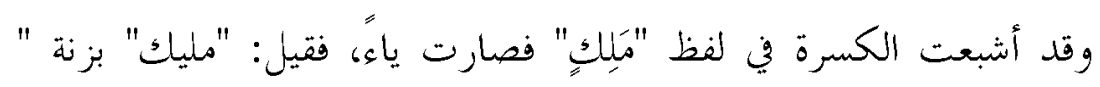

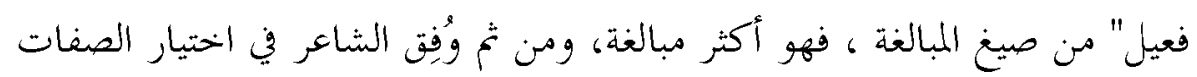

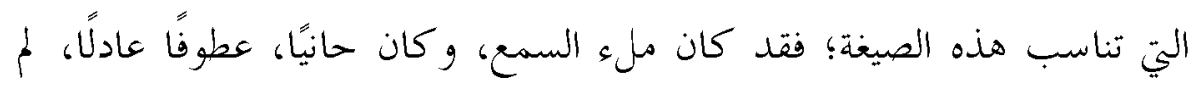

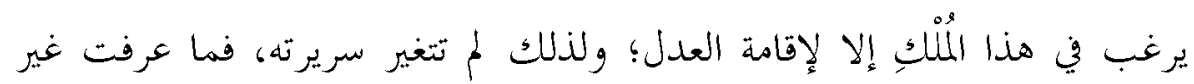


الطهر والنقاء.

وقد أصاب الشاعر في الجمع بين " مليك " و " زاهد " ، فهي إشارة قوية

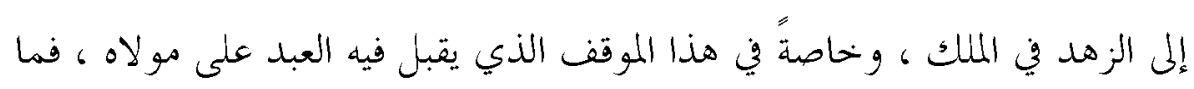

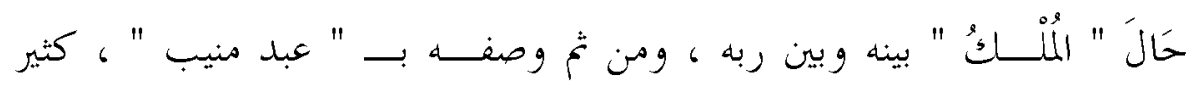
العودة والإنابة إلى ربه ، فإذا دعاه إله العرش أسعده النداء ، فترك الدنيا ملبيًا

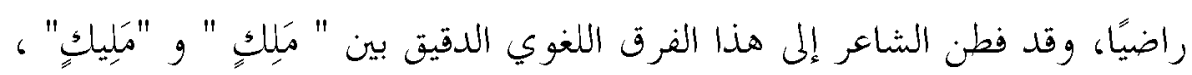

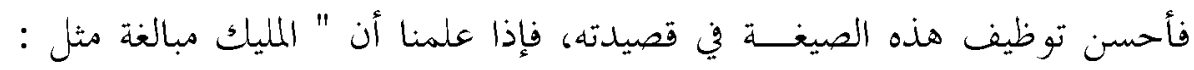

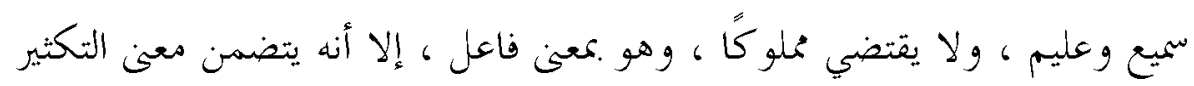

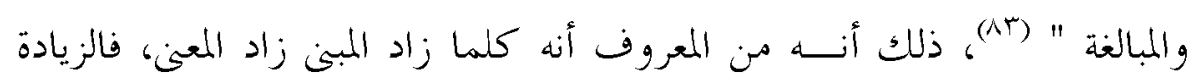

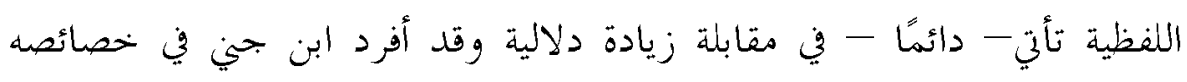

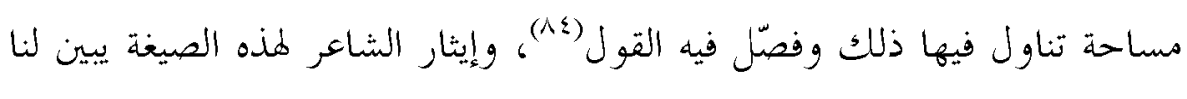

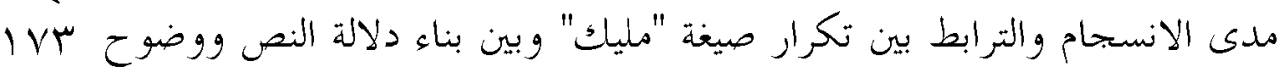

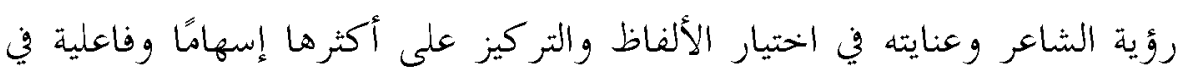
وضوح هذه الرؤية.

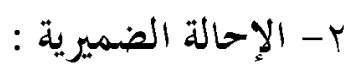

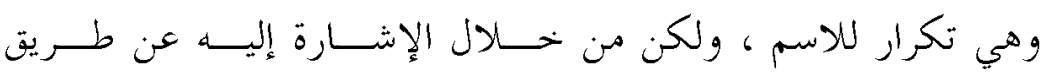

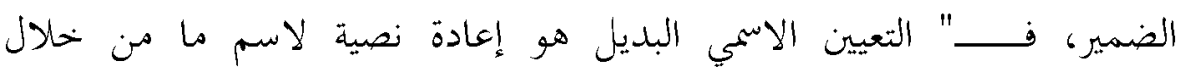

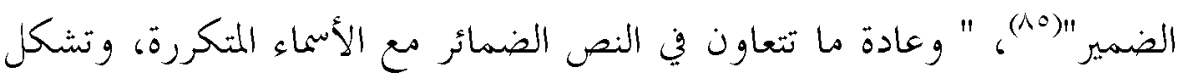

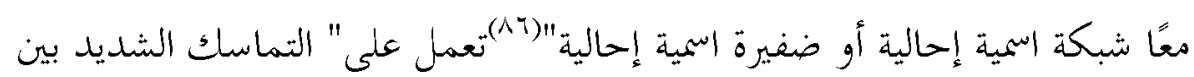

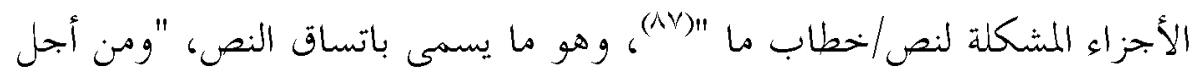

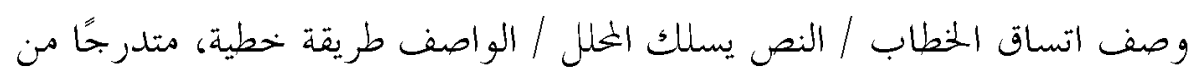

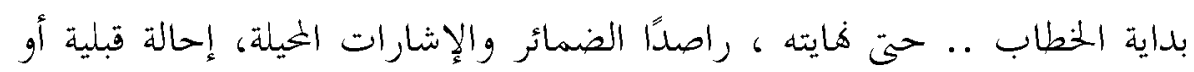

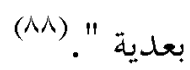


والضمير أعرف المعارف بعد لفظ المحلالة " الله " ؛ ولنا فهو يقوم " في نظر

علماء لسانيات النص بدور فعال مع عناصر الإحالة الأخرى في اتساق النص؛ لذا

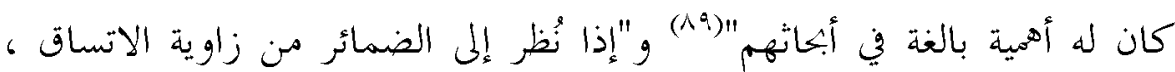
أمكن التمييز فيها بين أدوار الكالام التي تندرج تحتها جميع الضمائر الدالة على

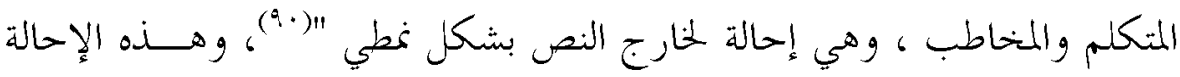
المقامية " تساهم في خلق النص ؛ لكوها تربط اللغة بسياق المقام ، إلا أها لا لا لإهال تساهم في اتساقه بشكل مباشر " (19)، ولكن هذه الإحالة تصبح إحالة نصية ،

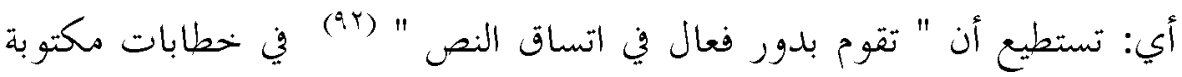

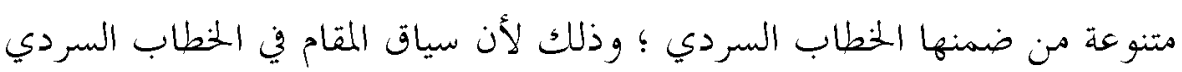
يتضمن " سياقًا للإحالة وهو تخيل ينبغي أن ينبين انطلاقًا من النص نفسه ، بحيث

$$
\text { أن الإحالة داخله يجب أن تكون نصية ". (r.) }
$$

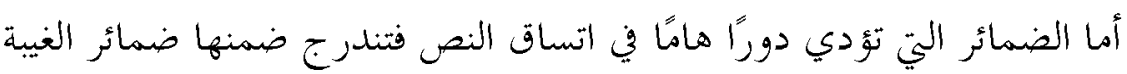

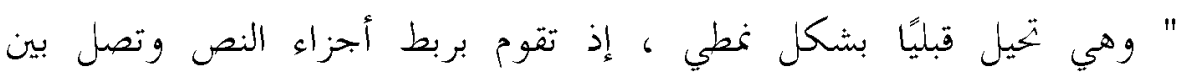

ومن خلال الإحصاء تبين أن الإحالة الضميرية في " المراثي " جاءت على اهلى

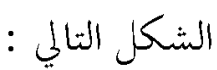

$$
\begin{aligned}
& \text { - ضمير المخاطب البارز " أنت " " الب " مرة . } \\
& \text { - ضمير المخاطب المستتر " أنت " " ^ی" مرة . } \\
& \text { - ضمير الغائب البارز " هو " لا" مرة . } \\
& \text { - ضمير الغائب المستتر " هو " مب ال " مرة . } \\
& \text { - - - ضمير الرفع " تاء الفاعل " " " " مرة . }
\end{aligned}
$$

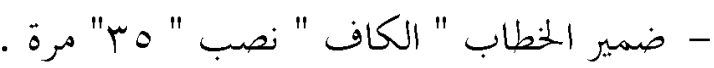

$$
\begin{aligned}
& \text { - ضمير الخطاب " الكاف " جر " بو " مرة . } \\
& \text { - ضمير الغيبة " الهاء " نصب " هم" مرة . }
\end{aligned}
$$




\section{ظاهرة التكرار}

$$
\text { - ضمير الغيبة " الهاء" جر "ب . ا" مرة . }
$$

من خحلال هذه القراءة يتبين تكرار الضمير الخحيل إلى " الملك خحالد " إحدى

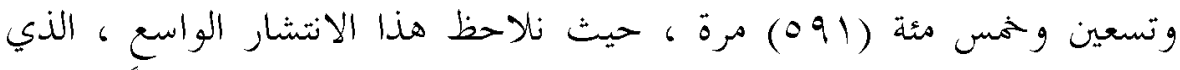
يسهم بدور واضح في تماسك البناء النصي للمراثي بكيث بيجعل منها كناً موحلدًا

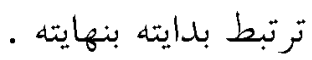

وإذا كان وصف اللسانيين بأن ضمير المخاطب " أنت " الذي تكرر في

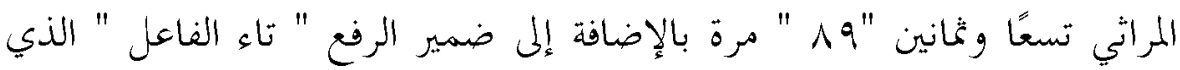

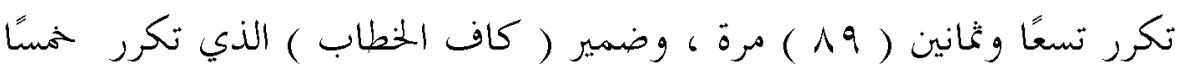

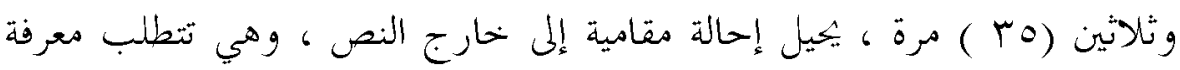

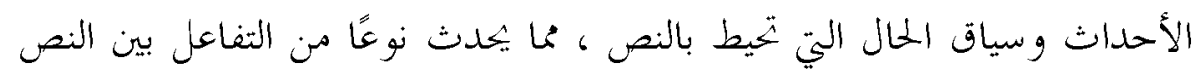

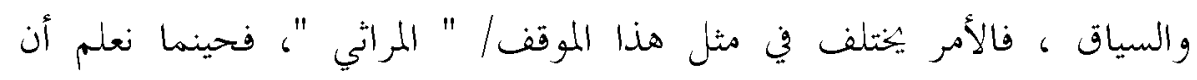

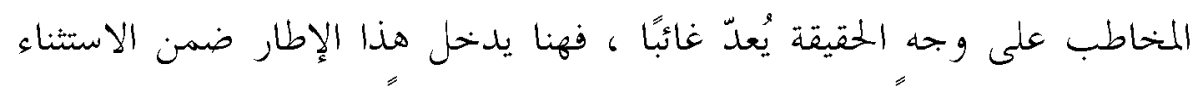

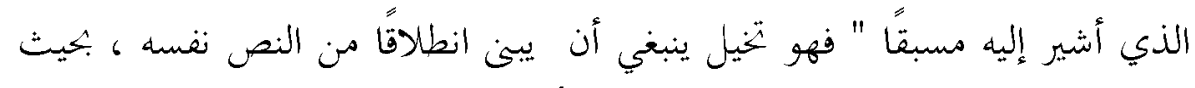

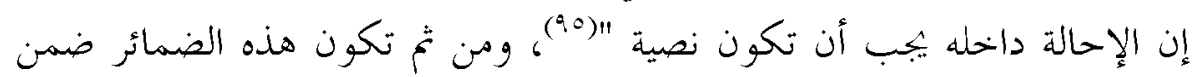

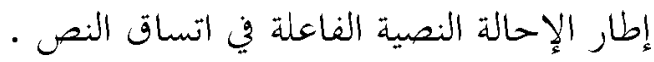

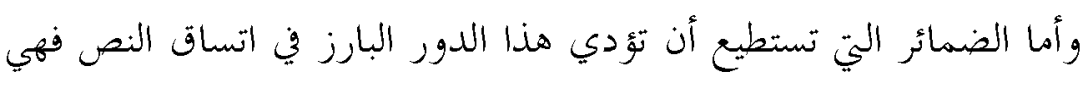

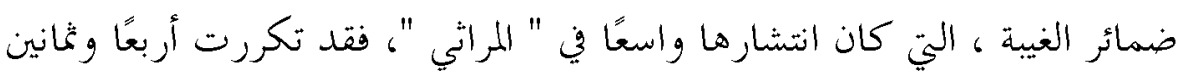

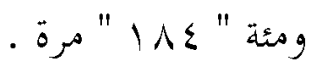

ويصدق كل ما قيل عن الضمائر الخهيلة إلى الشخص على " ضمائر الملكية

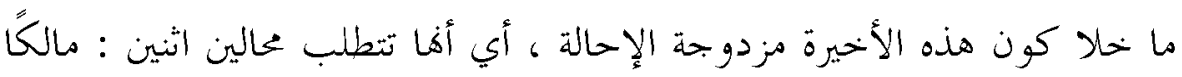
ونمانو

وقد تكرر ضمير الملكية أربعًا وتسعين ومئة ( ع 1 () مرة في " المراثي "، وهذا التكثيف الواضح للإحالات في " المراثي " أدى بصورة واضحة إلى تحقق التماسك الواضح بين أجزاء " المراثي " من البداية إلى النهاية ، ومن ثمث تعاونت الضمائر مع الأسماء المتكررة في تشكيل شبكة اسمية إحالية ساعدت في بناء نسيج 
النص ، ووضوح رؤية الشعراء في ماولة التكثيف الحضوري " للملك خالد " في

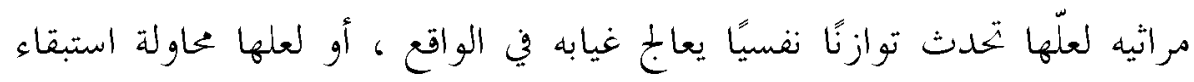
الذكر الحسن للإنسان في الحياة ، فهو العمر الثاني .

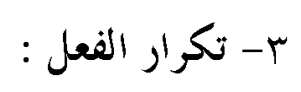

تكرر الفعل بصوره المختلفة في " المراثي "، و كان له الحضور الفاعل والمؤثر

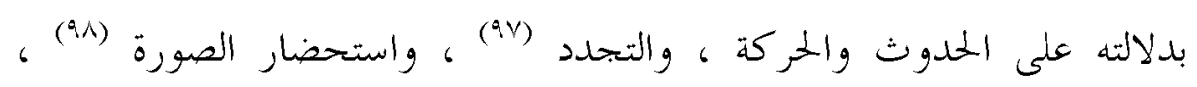

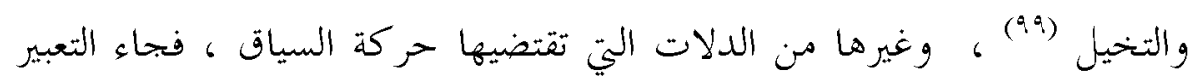
بالأفعال أكثر ملائمة هذه التغيرات الزمانية والدلالية ، وأكثر فاعلية في نقل

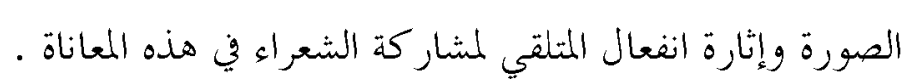
فمن نماذج تكرار " الفعل الماضي " قول الشاعر منصور سالم زنفلي :

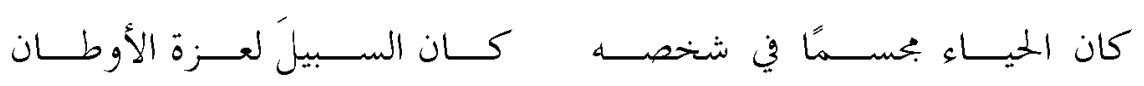

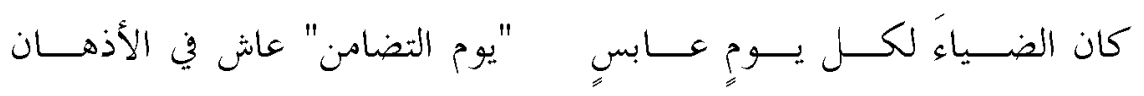

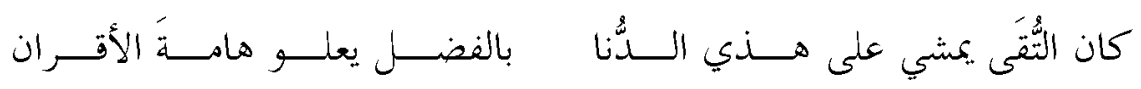

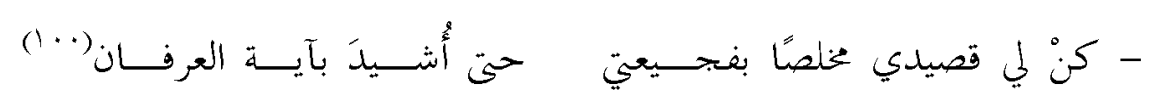
كرر الشاعر في الأبيات السابقة الفعل" كان " أربع مرات ، وجاء تكراره في ذلك على المستويين: الأفقي والرأسي ، ونلمح من هذا التحول إلى الزمن

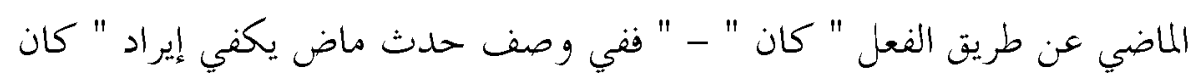
" في بداية الجملة ، وبهذا يتم خلق ماض يسري على ما يليه " (1.) - إيثار

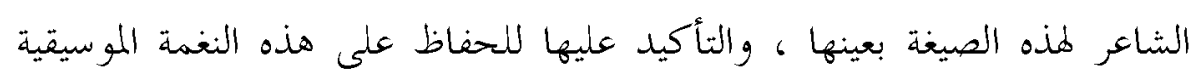

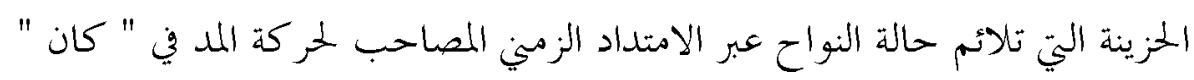
، منا يثير انفعال المتلقي وجذب حواسه لمشاركة الشاعر في هذه التجربة ، إضافة

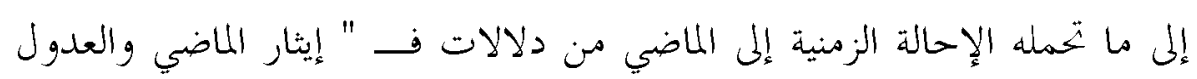




\section{ظاهرة التكرار}

إليه دال على مبالغة في الثبوت والاستقرار ".(1)

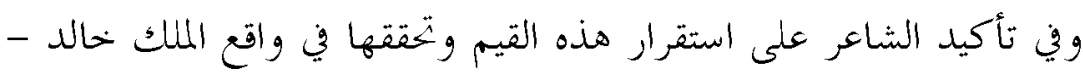

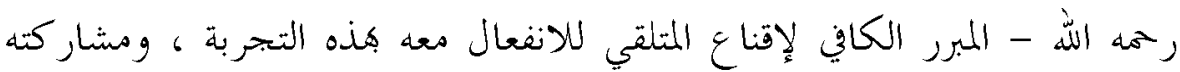
هذه المأساة التي أشار إليها في مطلع القصيدة :

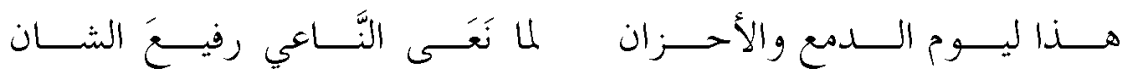
ومن ثم عرض هذه الصفات والمناقب التي كانت قديمة راسخة يلمسها العيان عبر الامتداد الزمين العميق ، فقد كان الحياء بحسمًا في شخصه ، فلم يقل : إنه

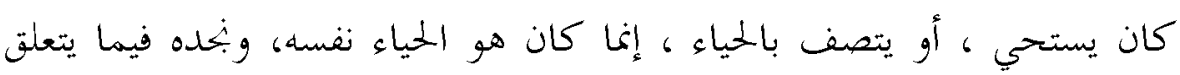

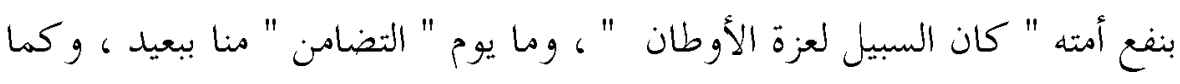

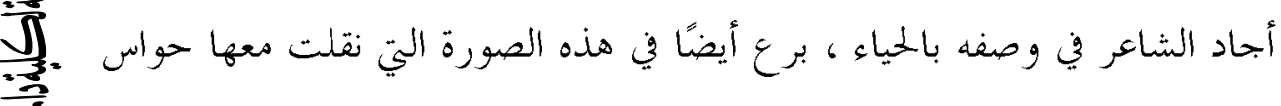

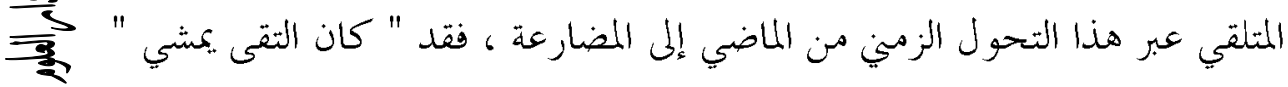

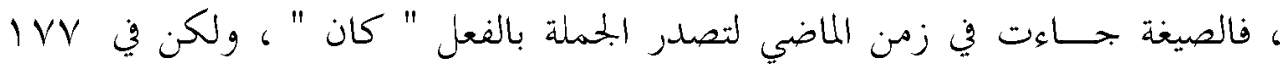

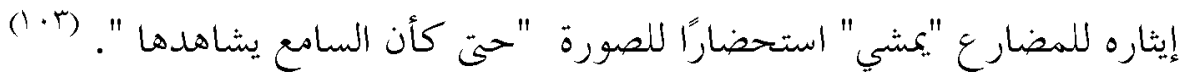

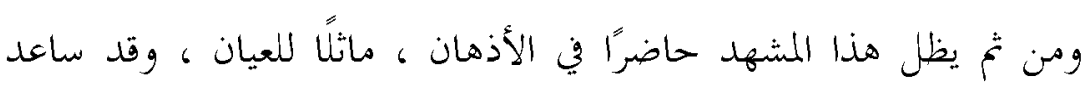
التعبير " على هذي الدنا " في بيان اتساع المساحة المكانية التي امتد إليها الأثر الدلالي الناتج من هذه الصورة وهو وصفه بالتقى ، وليس الوصف مقتصرًا على لئى

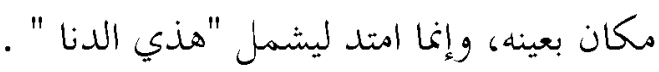
وفي سبيل هذا التأثير من المبدع ، و والتأثر لدى المتلقي يسلك الشاعر تحون أكثر فاعلية في بناء الصورة ، فيتحول عن الإخبار بصيغة الزمن الماضي إلى الإنشاء

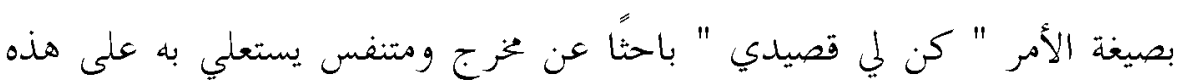
الأزمة التي ألمت به ، فيتمثل هذا المخرج في اللجوء إلى الشعر ، فمن خلاله

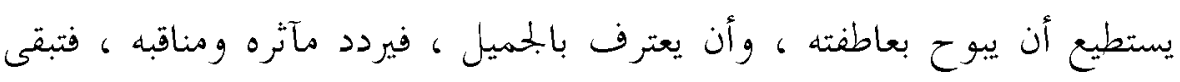
خالدة متجددة على مر الزمن · 
ويقول الشاعر :

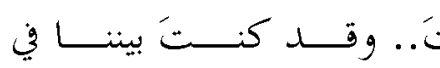

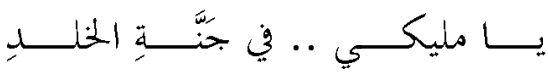

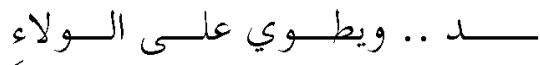

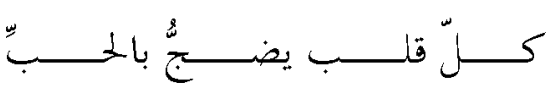

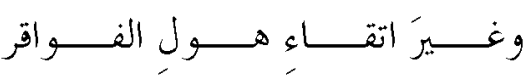

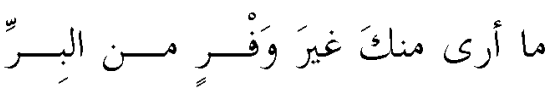

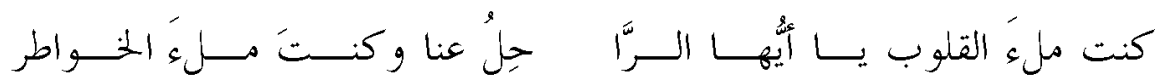

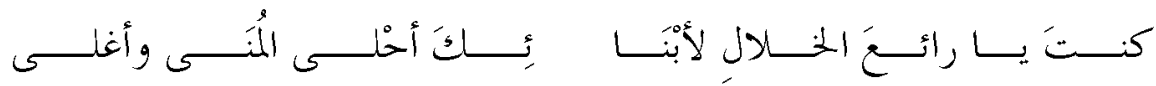

استهل الشاعر قصيدته بأسلوب النداء الذي ينشط الحركة في داخل

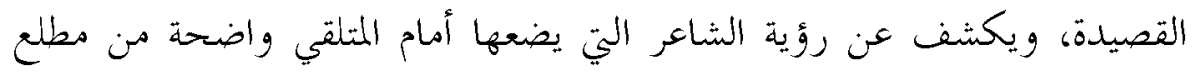

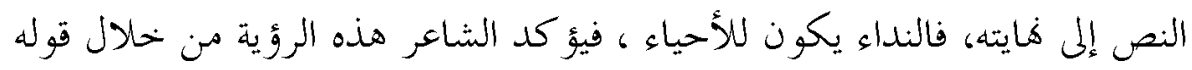

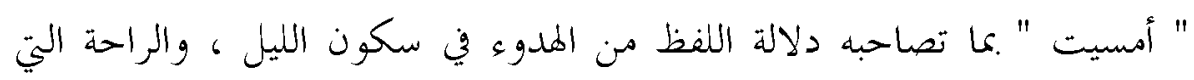

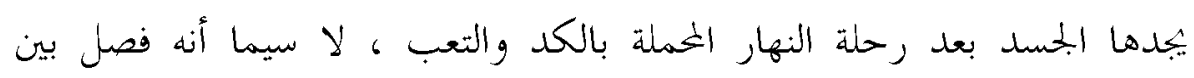

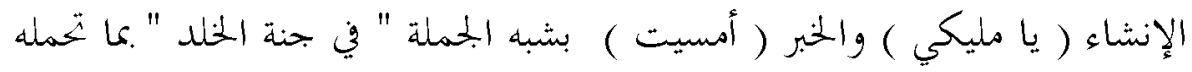

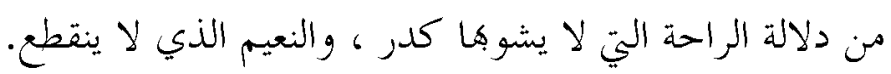

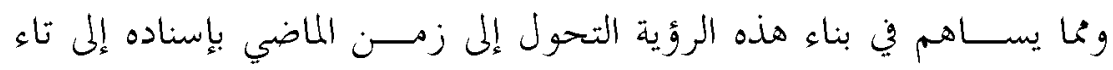

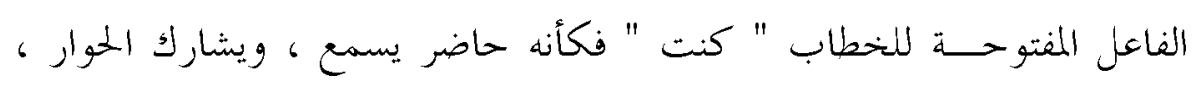

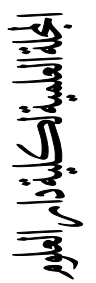
IVA وقد سبق بـــ" قد " التي بيّن القدماء أترها في التأويل الزميز للجملة ، بإفادة تقليل

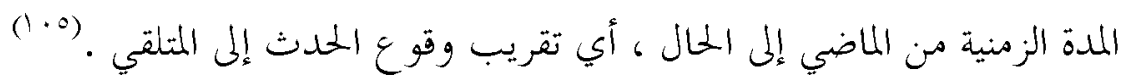
ويمضي الشاعر في كشف ملامح الصورة ، من خلال ارتكازه على تكرار

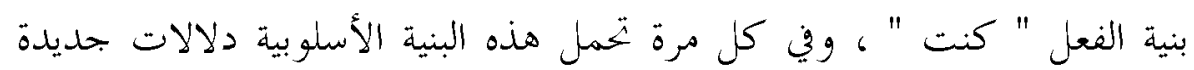

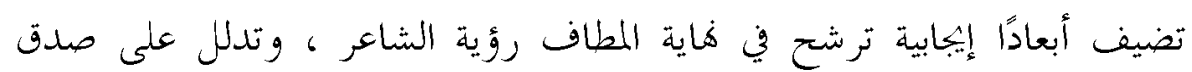

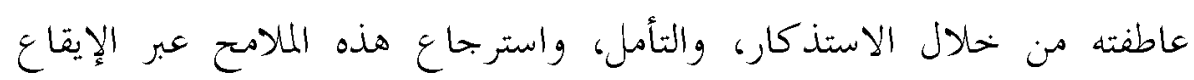

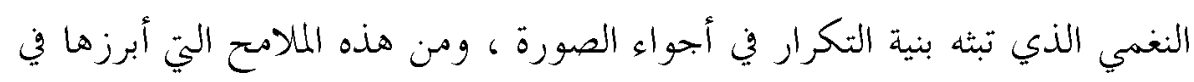

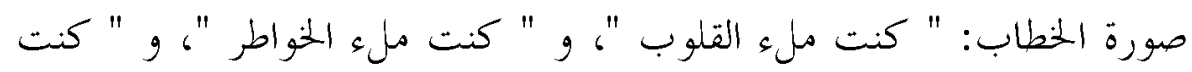




\section{ظاهرة التكرار}

أحلى المنى وأغلى الذخائر "، ولا يزال الشاعر ينسج هذه الملامح التي تشكل

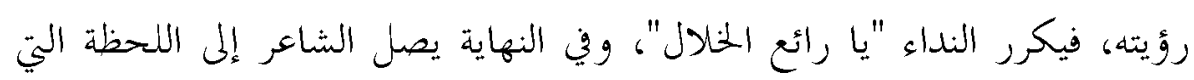

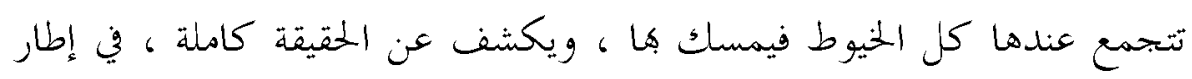

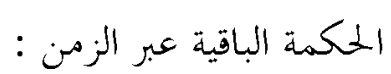

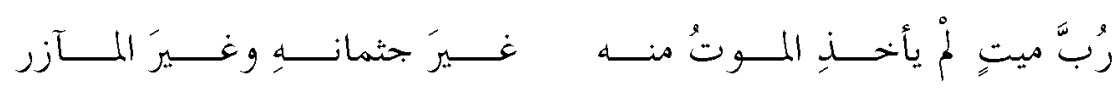

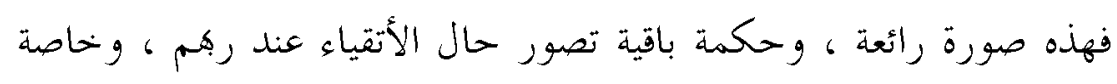

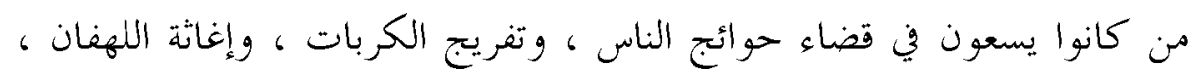
ونصرة الحق والاهتمام بقضايا الأمة .

\section{ويقول الشاعر :}

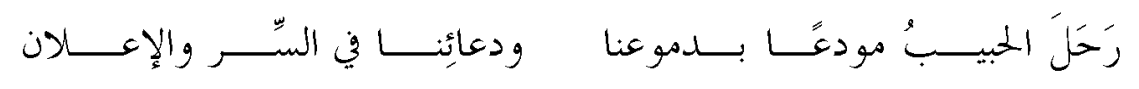

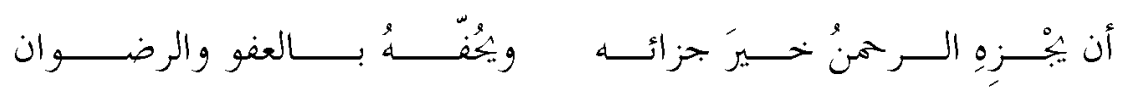

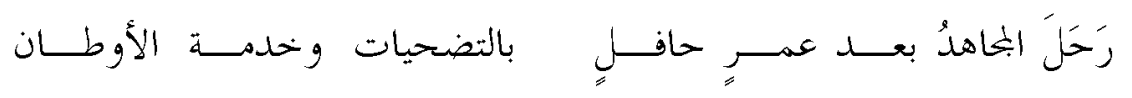

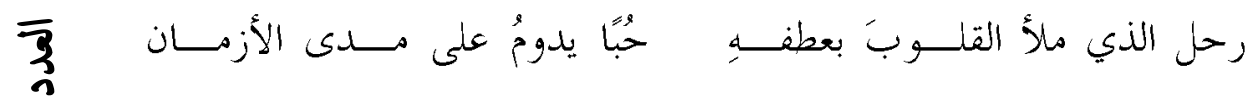

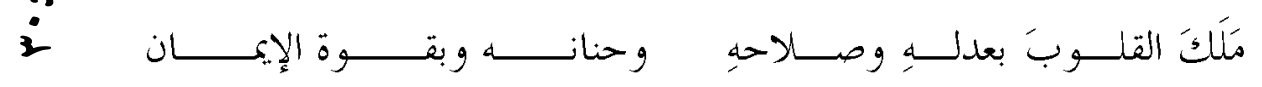

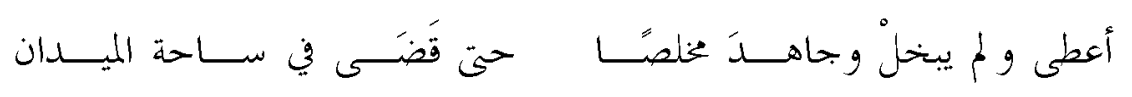

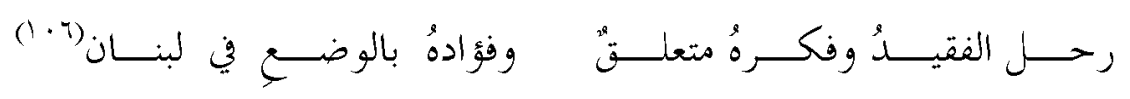

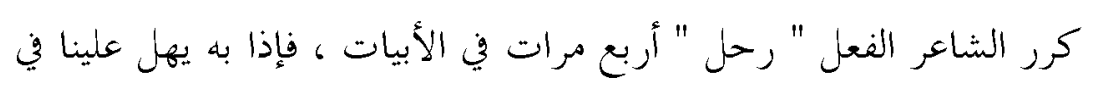

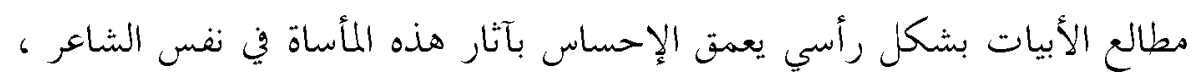

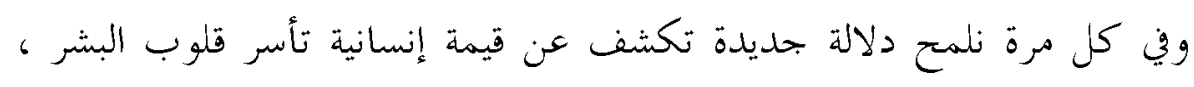

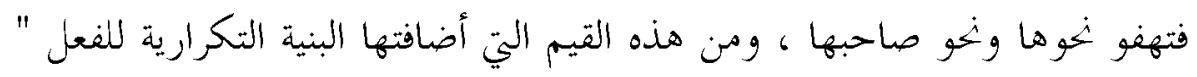

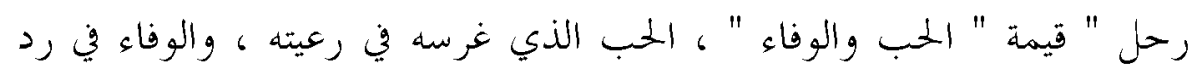

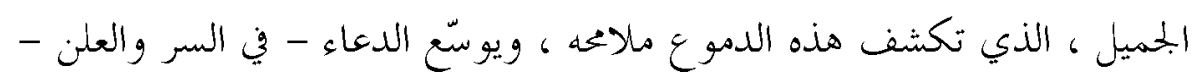

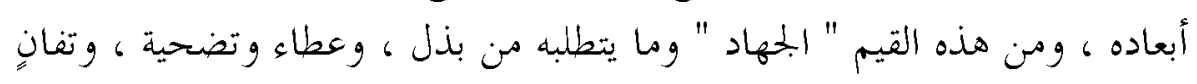




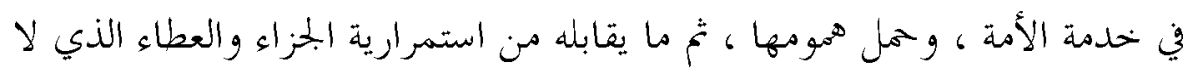

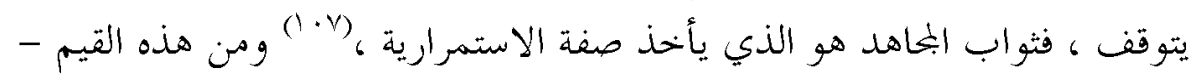

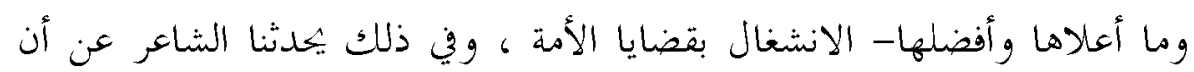

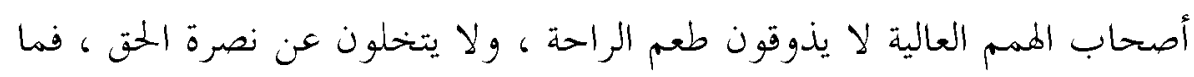

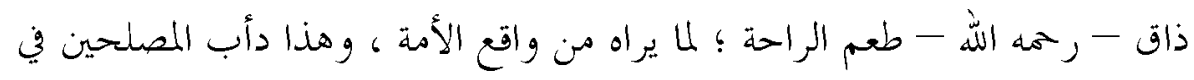

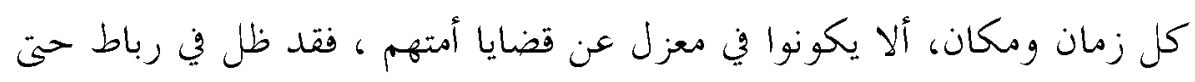

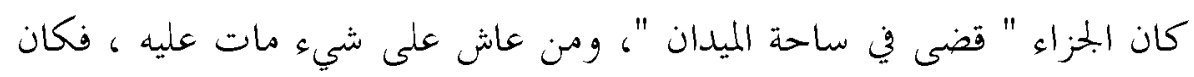

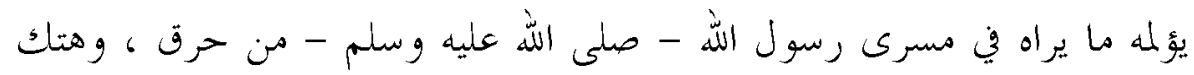

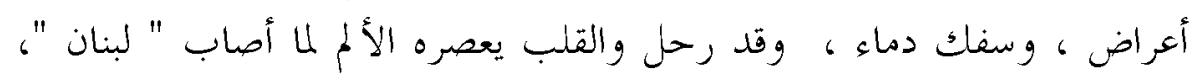

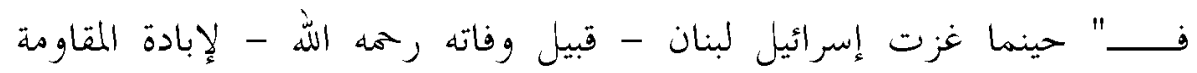

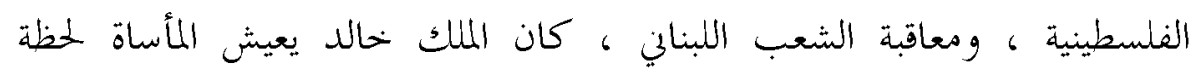

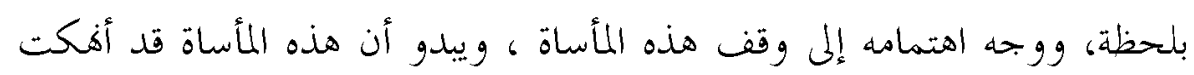
قلبه". (1) (1)

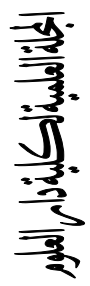

إذن فقد كان هدفه واضحًا ، وسبيله واضحة وهي جمع كلمة الأمة ، وتوحيد صفها ، وإزالة الحلاف والنزاع ، فبذل الجهود في سبيل تحقيق هذه الوحدة ، التي هي الطريق إلى ردّ العدوان واسترداد مقدسات الأمة المغتصبة وحفظ كرامتها . ويقول الشاعر :

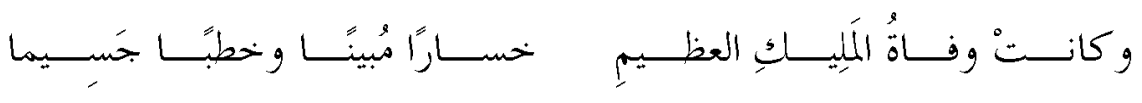

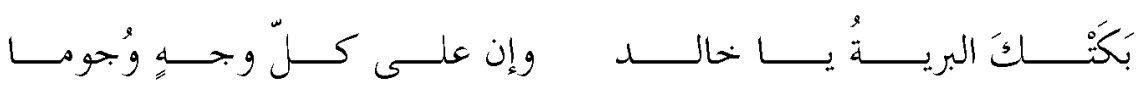

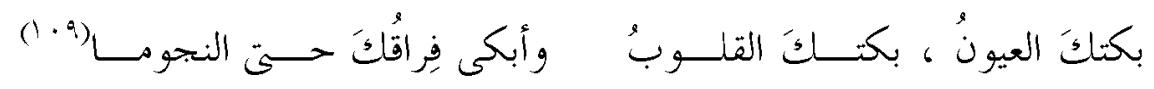
تعد بنية التكرار المرتكز الرئيس الذي يوضح رد فعل الشاعر بتاه الخحنة ، بل

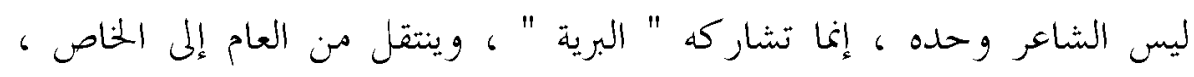
فالعيون تبكي ، والقلوب تبكي ، بل تتأثر الطبيعة هي الأخرى، فتبكي النجوم 


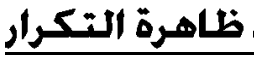

على فراقه ، فـــ" البكاء إثر فراق الأحبة قضية إنسانية عامة تتصل بالذات

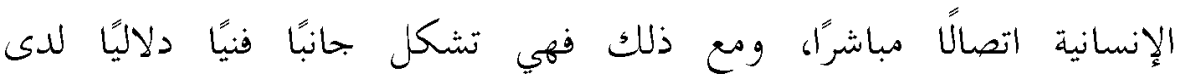

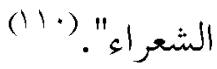

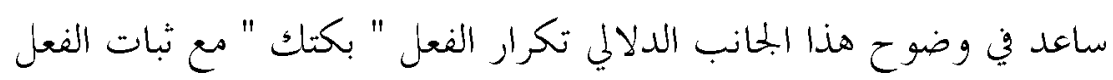

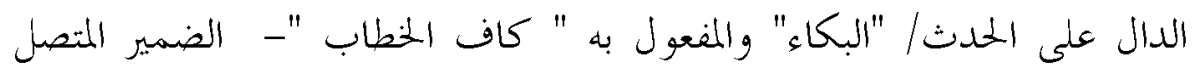

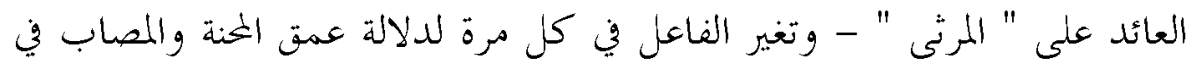
النفوس ، ثم يعدل عن الصيغة إلى صيغة أخرى تلائم سياق الحدث ، فئساء

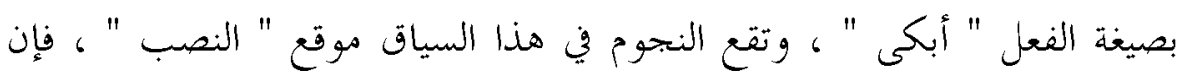

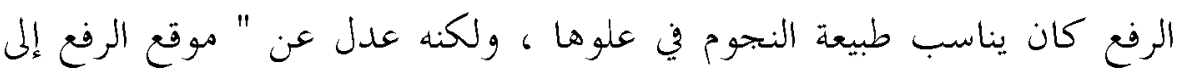

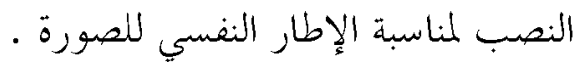

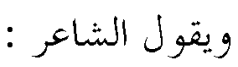

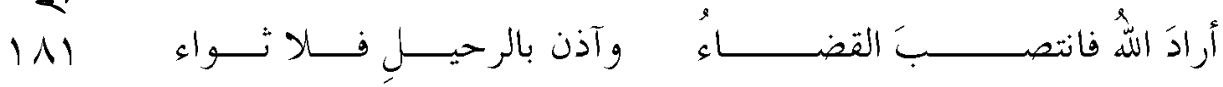

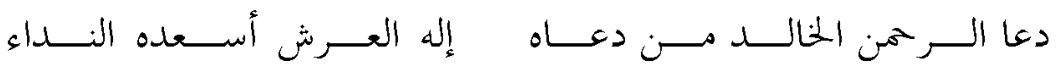

يقودُ خطى كرامتــــا الونــاء

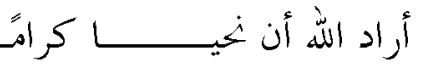

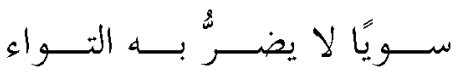

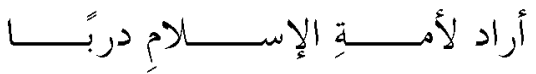

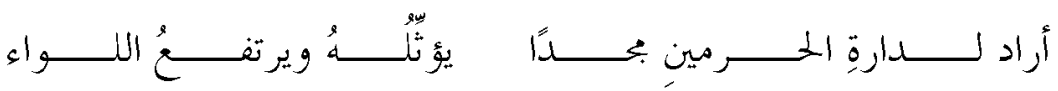

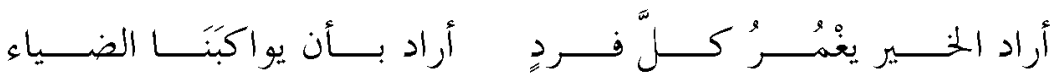

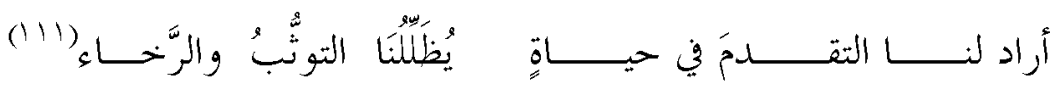

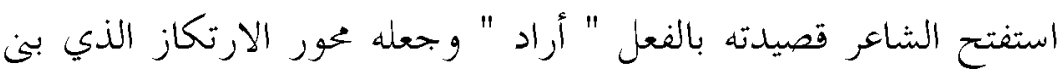

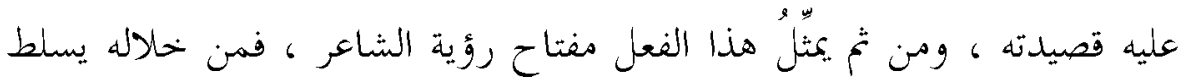

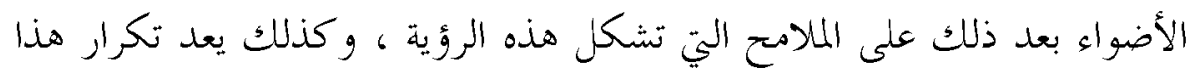


الفعل شكاً من أشكال "الاتساق المعجمي ، الذي يقوم بدور فعال في اتساق

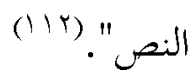
ومفهوم الاتساق يأخذ " بعين الاعتبار العلاقات في الخطاب "("'ا") وبناء" عليه بند أن استهالال الشاعر قصيدته بقوله : " أراد الله " بمثل الترابط الدلالي

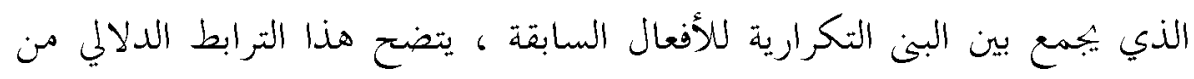
خلال هذا الترتيب " كان - رحل - بكت - أراد اللّ ". فقد قام تكرار الفعل " كان " برسم الملادح الجمالية التي مثلتها صفات الملك " خالد " رحمه الله ، وتحقتها واستقرارها في واقع الأمة ، ثم يأتي الرحيل

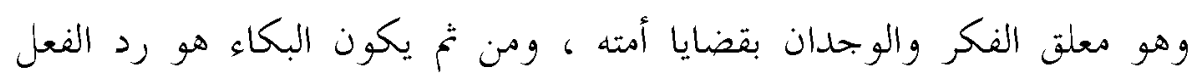

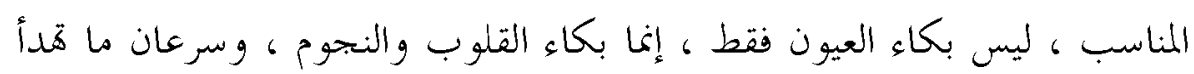
النفس ، ويرضى القلب ، وتسكن الجوارح عندما تواجهة بهذه الحقيقة ، إذا إرادة الذّ الذّ

وقد أخذ الشاعر ينسج هذه الملامح الجمالية التي أرادها الله لهذه الأمة من

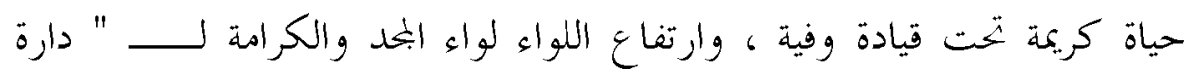

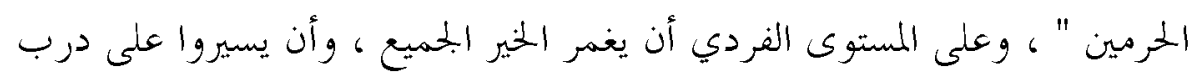
التقدم والرخاء الذي ارتضاه الله لهذه الأمة . ومن نماذج تكرار صيغة الفعل الماضي قول الشاعر :

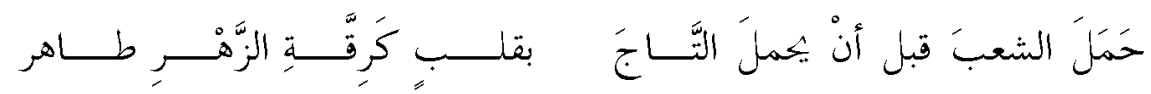

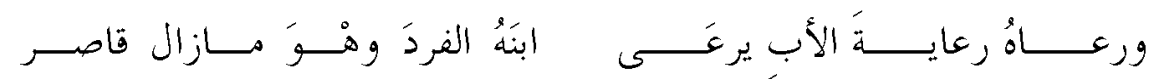

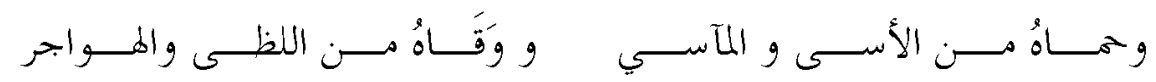

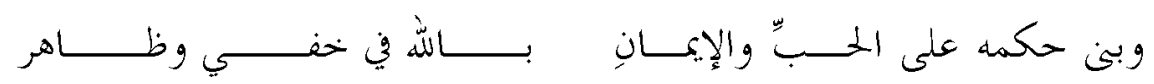

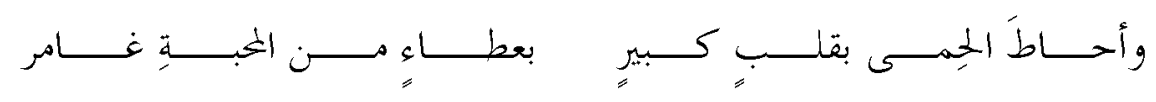




\section{ظظاهرة التكرار}

( (I气)

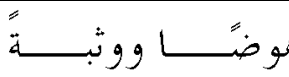

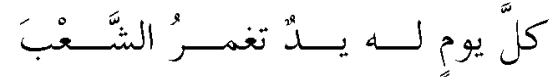

فقد وظف الشاعر صيغة الفعل الماضي ( حمل - رعاه - حماه ...) لتأكيد

حدوث هذا المعنى والقطع بوقوعه ، فقد قام على رعاية شعبه كما يقوم الأب على رعاية ولله ، و لم يقل أولاده ، و إنما اختار صورة الأب الذي لا بملك إلا هذا الولد ليس له غيره ، فتراه يسخر كل حياته لخدمته ، وبهيطه بالرعاية والحب - الغامر

وونن ناذج تكرار الفعل المضارع قول الشاعر :

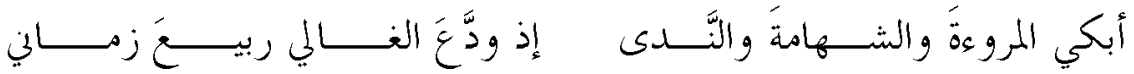

牙

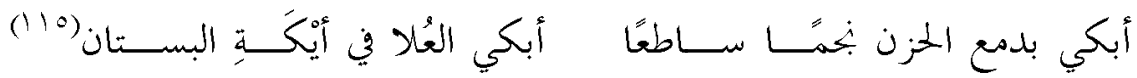

تكرر الفعل " أبكي " بصيغة المضارعة اليت تدل على الديمومة والاستمرارية؛

فالبكاء لا ينعطع وذرف الدمع لا يتوقف ، وإن هذا وذاك ليزيد من فاعلية التصوير ، واستحضار المشهد ، وإثارة انفعال المتلقي إزاء هذه التجربة الإنسانية سم إم التي صرح الشاعر في مطنع النص بعموميتها "هذا ليوم الدمع والأحزان"، ومن ثم يستطيع المتلقي أن يقف على أبعاد هذه التجربة ، فيكون قريبًا من المبلاع ، حينما يكشف عن صفات المغارق : " المرووة ، و الشهامة ، والندى " ، وهذه الصفات

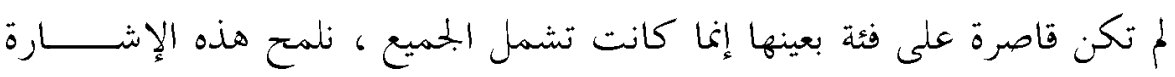
من اختياره للفظذ " الندى" فهو اسم للجود الذي ينال القريب و البعيد ". (11) ومن ناذج تكرار صيغة الفعل المضارع قول الشاعر :

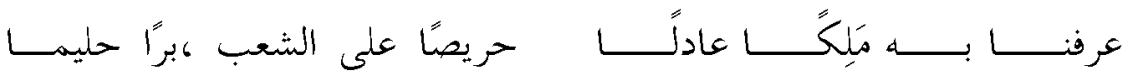

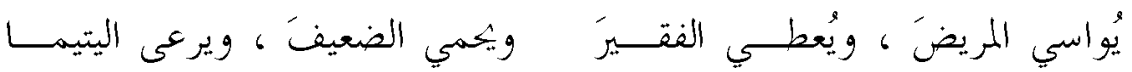

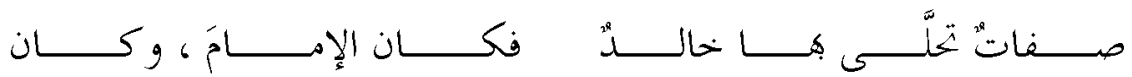
استطاع الشاعر أن يلمس الملانب الإنساني في حياة المللك خالد - رحهد اللّ - لمستا مؤثرًا م، من خلال التكرار المتتابع لصيغة المضارعة ، وقد ساعدت البنية 
الإيقاعية من خلال حسن التقسيم في إثارة حواس المتنقي؛ لمتابعة هذه الصور الجزئية اليت تتضافر جميعها في رسم ملامع هذا الجانب الإنساني ، فالعاطفة

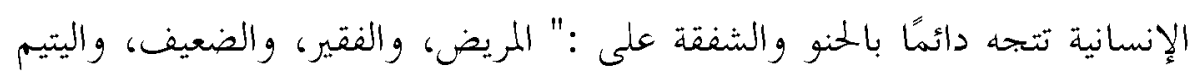

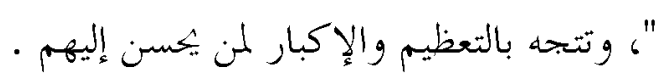

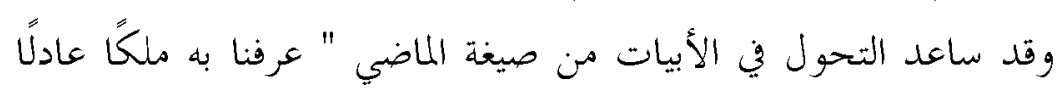

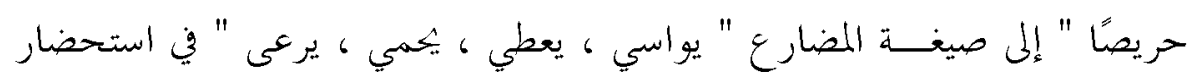

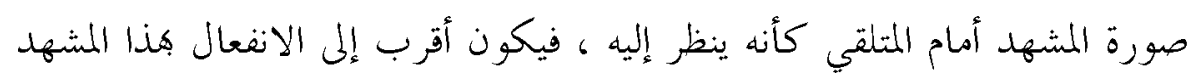

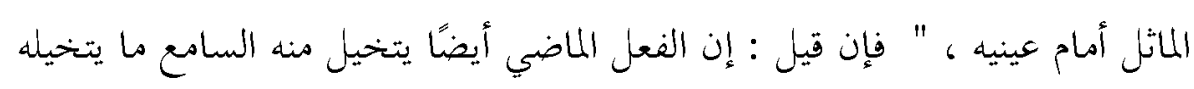

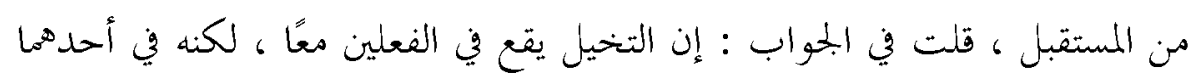

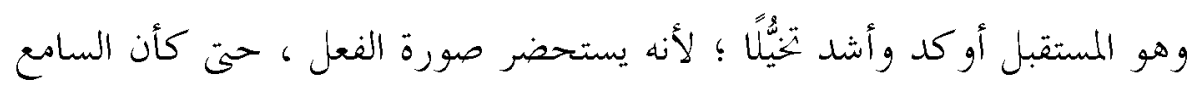

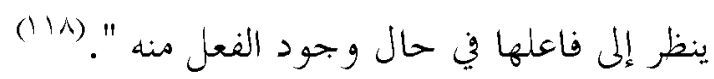

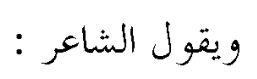

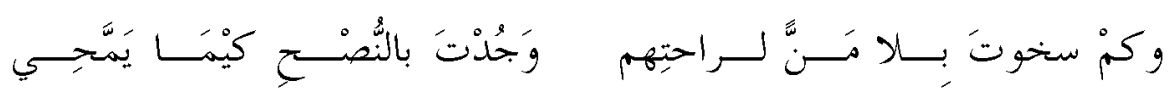

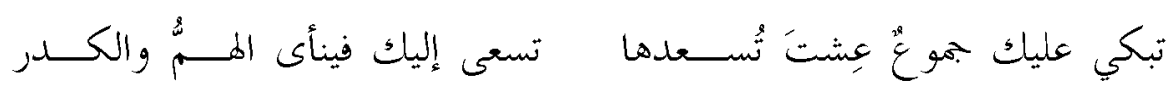

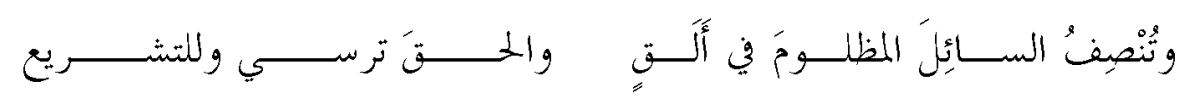
فقد كرر الشاعر في هذه الأبيات صيغة المضارع " تبكي - تسعدها تسعى - ينأى - تنصف - ترسي - تنتصر " ، وتوّل - أيضًا - عن صيغة الماضي " سخوت - جُدت " إلى صيغة المضارعة ؛ لاستحضار هذه المشاهد

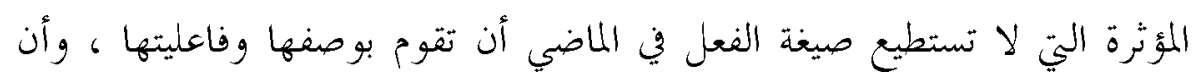
تصف امتداد أثرها في واقع الأمة ، حتى بعد رحيل صاحبها ، وهي إنى إنارة أراد

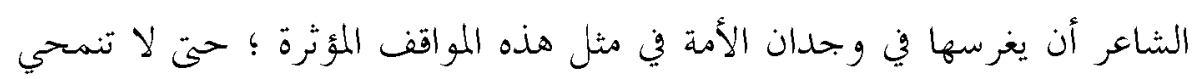

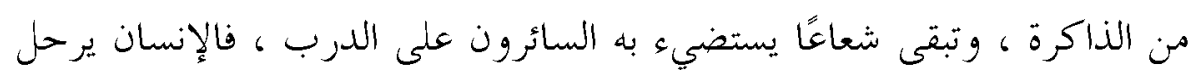

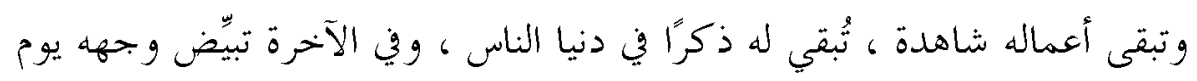




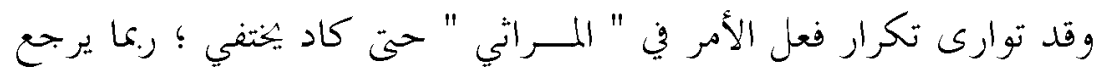

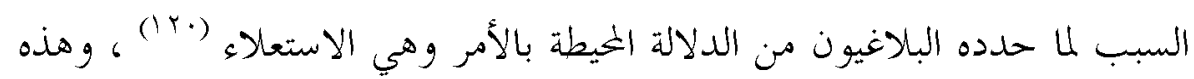

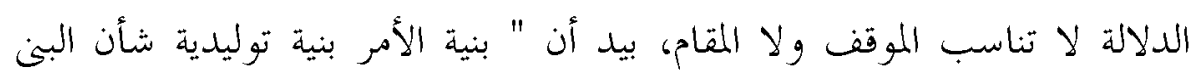

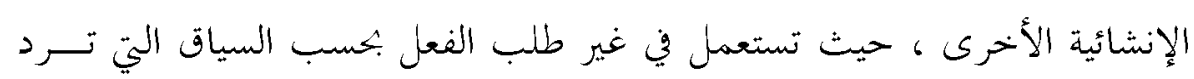
فيه ". (1) الإناية

$$
\text { فمن نماذج تكرار فعل الأمر قول الشاعر : فئ }
$$

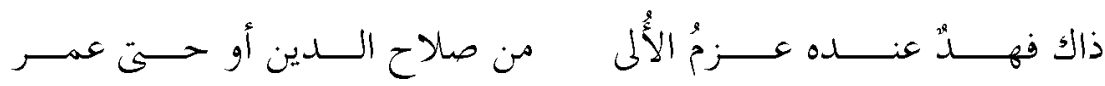

矛

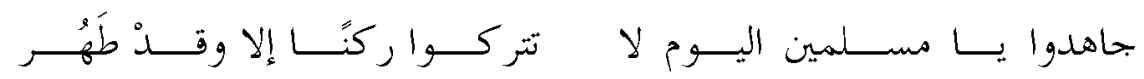

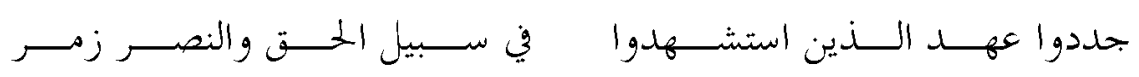

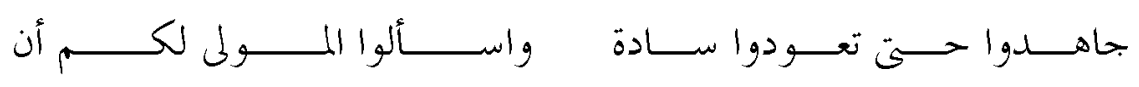
ساعد تكرار فعل الأمر " جاهدوا " على تنشيط الحركة داخل القصيدة ،

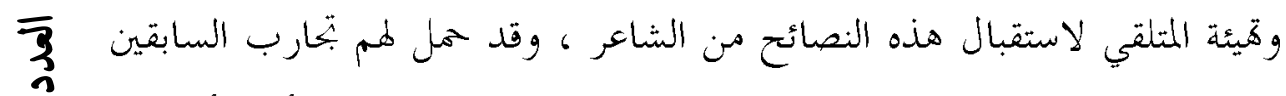

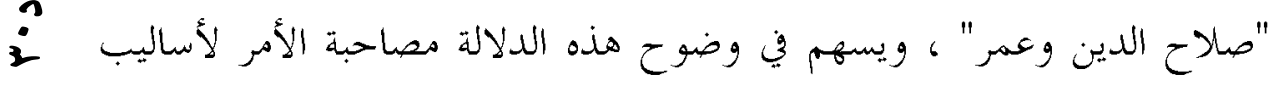

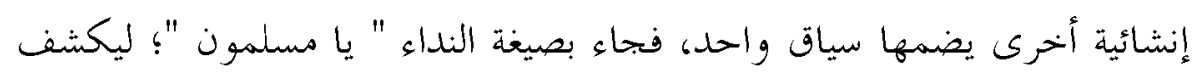

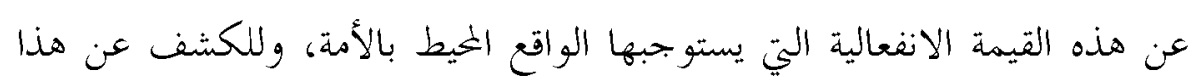

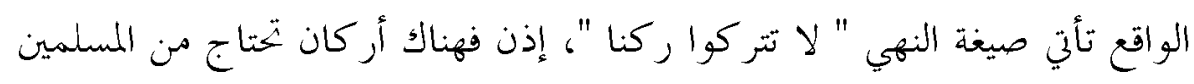

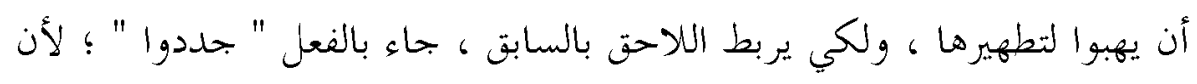

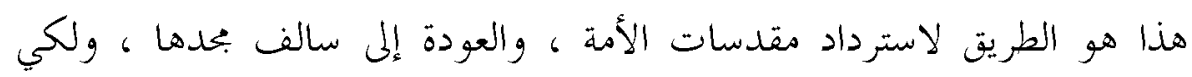

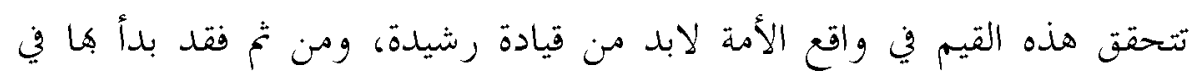

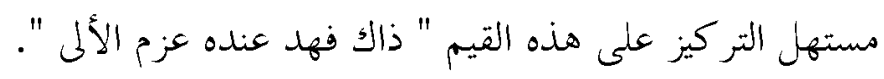

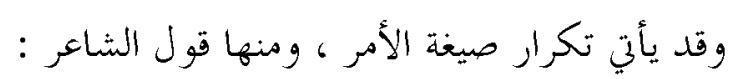



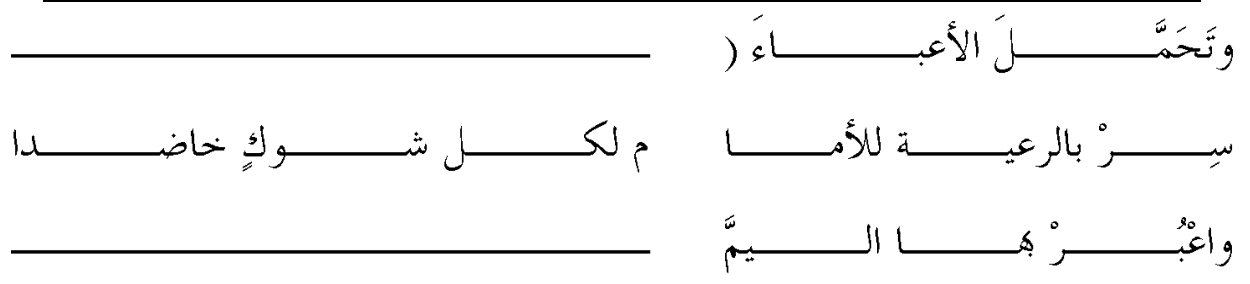

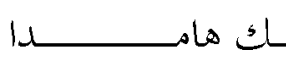
ت

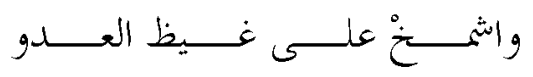

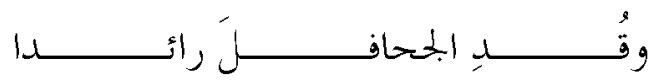
ئر íng

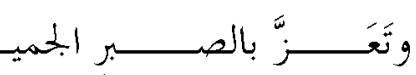

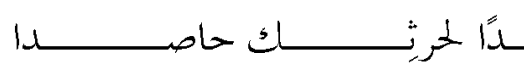

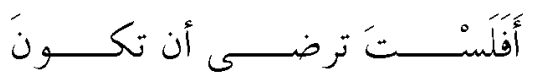
$\left.(I)^{M}\right)_{d}$ olj Sو:

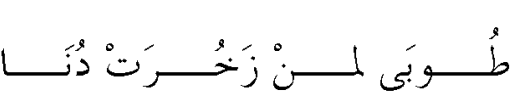
نستطيع من عنوان النص " فأقام فهذًا راعيًا " أن نتبين رؤية الشاعر بجاه الموقف ، فقد ركز في رثائه للملك خالد - رحمه الله - على الجوانب الإيجابية المضيئة في حياته ، و لم يقف عند هذا الحلد ، بل جذب انتباه المتلقي منذ عنوان النص إلى هذا البعد الإيبالي الذي ينفع الأمة بعد محاته ، وهو اختيـار المللك "فهد" و " قد ارتضاه تدئّا " " " فأقامه راعيًا " وقد كان عند حسن الظن به " فتحمل الأعباء في ثبـــات "ن و كأن الشاعر يريد أن يرجع بذاكرتنا إلى تلك الصفحة البيضاء في عصر الخلافة الراشلة ، حينما يجلس الخليفة في تواضع وخشوع يستمع ، والعلماء و الوعاظ ينصحون ، فأخذ يتوجه بالنصح " سر بالرعية "، و نلاحظ تأكيد الشاعر على هذه القيمة " الراعي / الرعية "، وما تحمله من دلالة الأعبــاء والتبعات

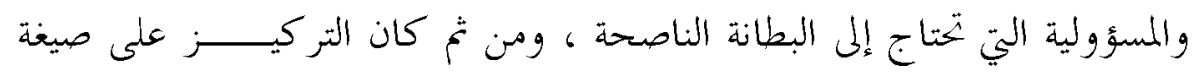
الأمر في استهلال الأبيات " سر ، اعبر ، الثمخ ، أنر ، تعز ". إذن فالتبعة ثقيلة تلعو - بلا شك - إلى الإحجام عنها ، ولكن الشاعر يكمل الصورة مكا يهون هذه المشاق ، وومسح العناء في هاية المطلف ، من خلال 


\section{ظطاهرة التكرار}

هذا الاستفهام التقريري ، " أفَلَّت ترضى أن تكون غدًا لخرثاك حاصدا " ،

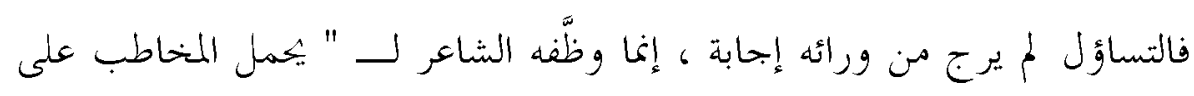

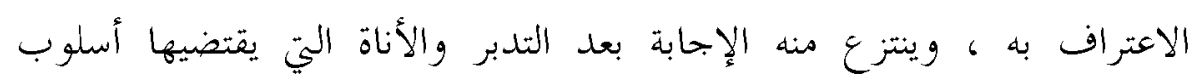

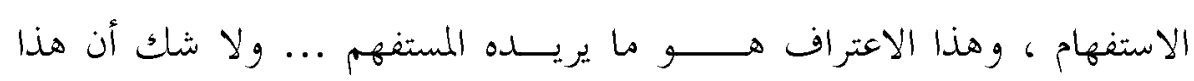

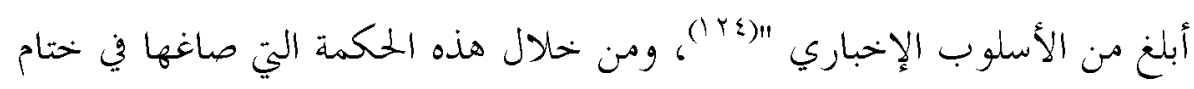

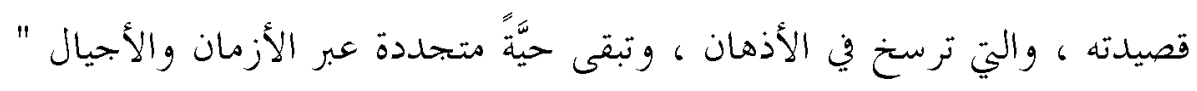

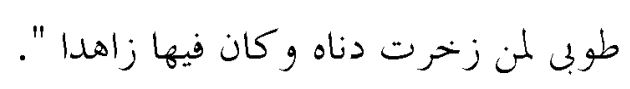

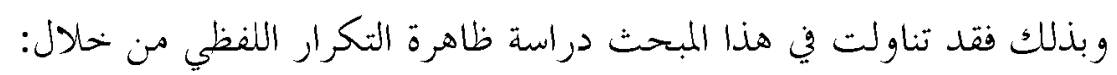

变 تكرار الاسم ، والإحالة الضميرية ، وتكرار الفعل، وفي المبحث التالي سألقي INV

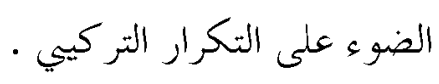

米垱

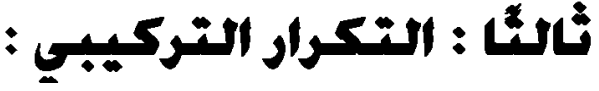

إذا كانت بنية التكرار على مستوى الأصوات أو الألفاظ ذات دلالة الهات

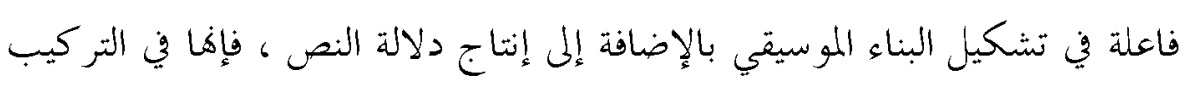

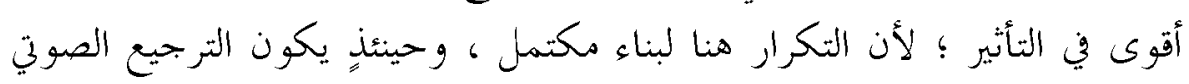

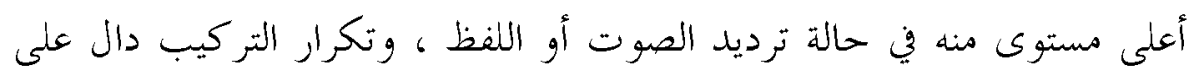

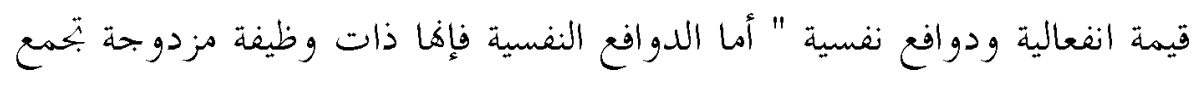

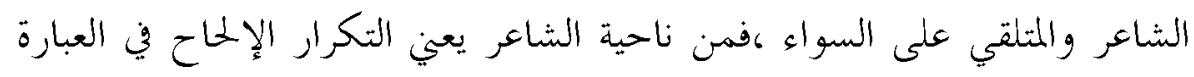

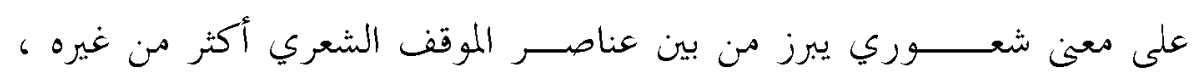

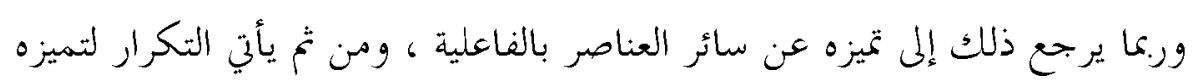
بالأداء " (ro)

وأما الأثر النفسي من ناحية المتلقي فإنه " يصبح ذا تجاوب يقظ مع البعد

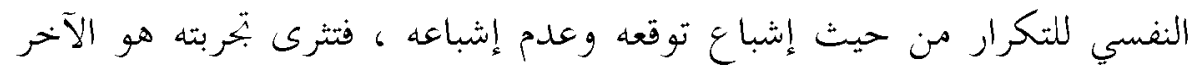

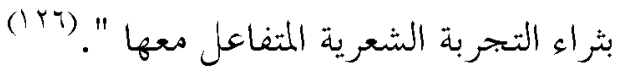

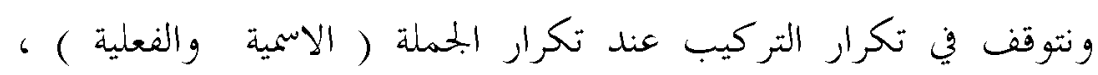


وتكـــــرار شبه الجملــلة، وتكرار شطر البيت، و السطر الشعري ، وتكرار

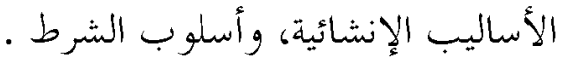

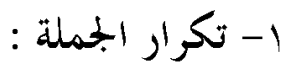

$$
\begin{aligned}
& \text { أ) فمن تكرار الجملة الاسمية قول الشاعر : }
\end{aligned}
$$

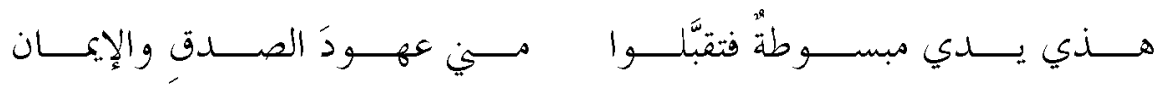

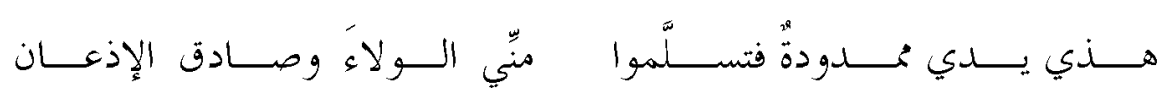

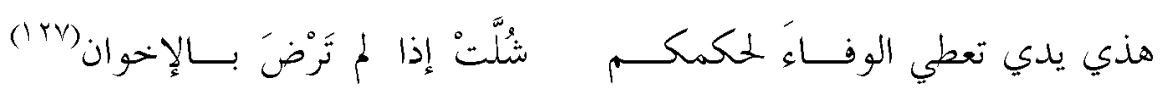
فقد تكرر قول الشاعر : "هذي يدي " في استهلال الأبيات ، وجاء على لى النحو التالي في البيت الأول، والثاني : - هذي يدي ( مبسوطة ) ( فتقبلوا ) مين .

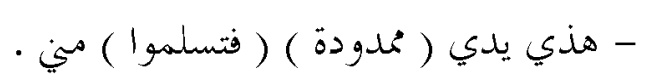

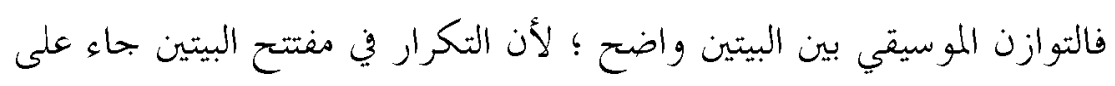

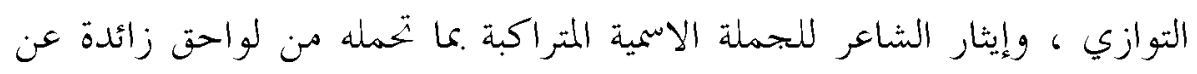

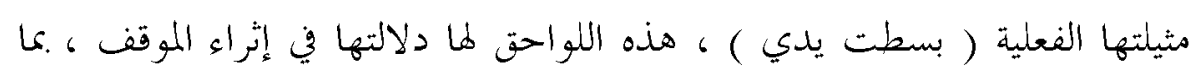

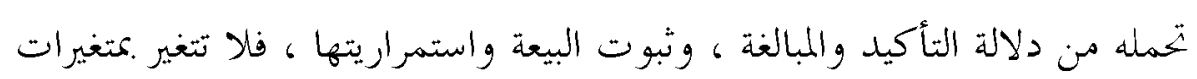
الأحداث

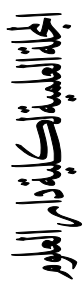
$1 \wedge 1$

وتتضح هذه القيمة الانفعالية التي أراد الشاعر أن يؤكد عليها من خلال عدوله عن التعبير بالجملة الفعلية (تعطي يدي الوفاء لحكمكم) إلى التعبير بالجملة

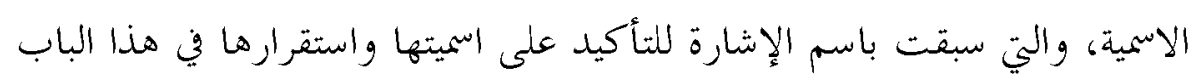

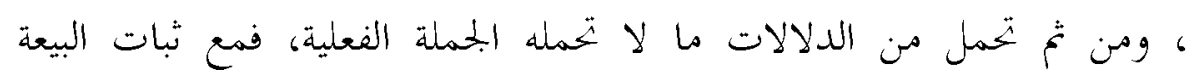
واستقرارها، بخد بتدد الوفاء ، وما يتطلبه من قرائن دالة متجددة . وقد تكررت صيغة " الجمملة الاسمية " ، ولكن مع تغيير " المسند " وثبات "المسند إليه" ، ومنه قول الشاعر : 


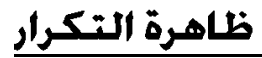

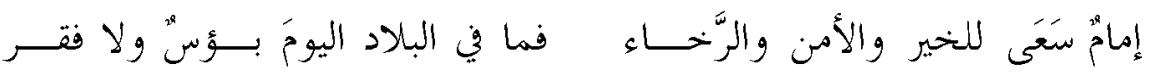

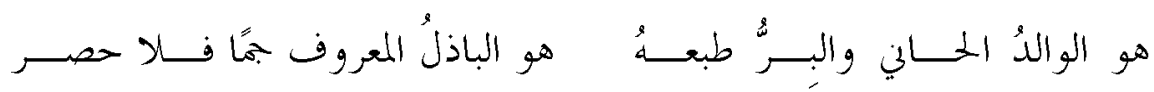

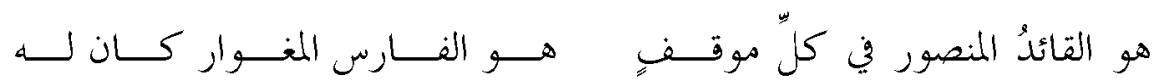
فقد تكررت صيغة " الجملة الاسمية " مع ثبات المسند إليه " هو " ، و وتغيير

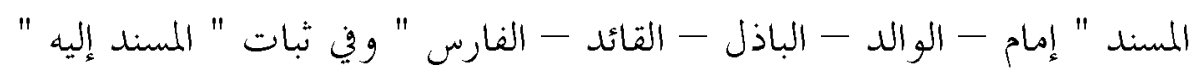

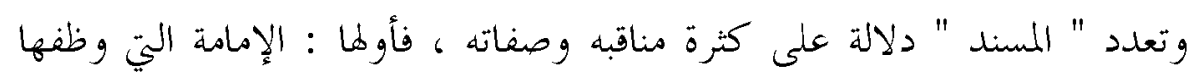

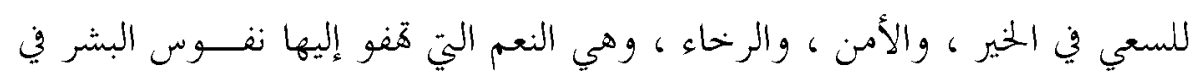

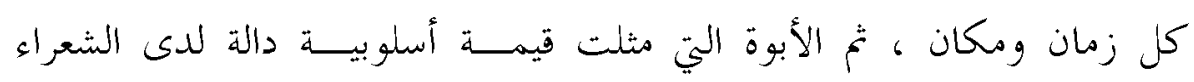

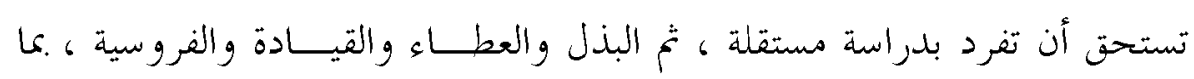

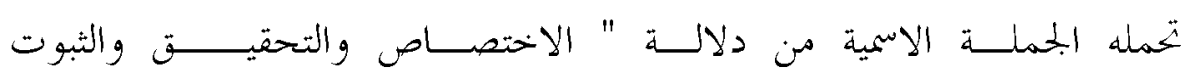
(1 99 ) 11

ب) ومن نماذج تكرار الجملة الفعلية قول الشاعر : 119

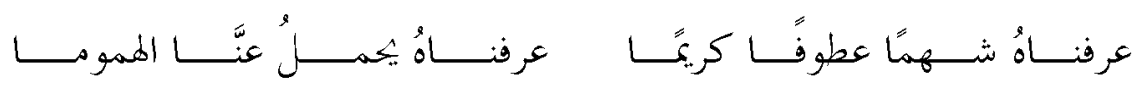

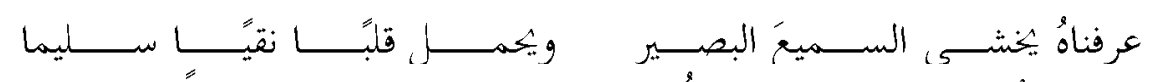

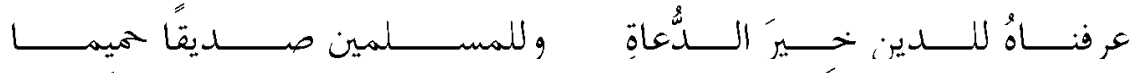

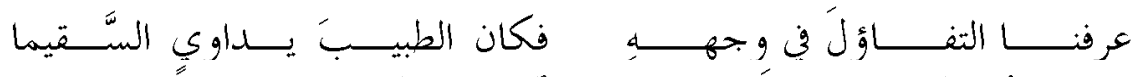

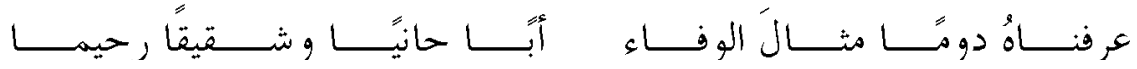

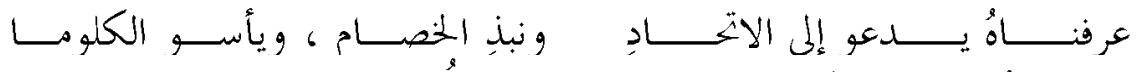

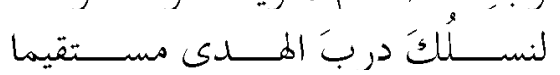

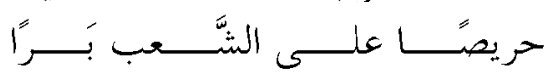

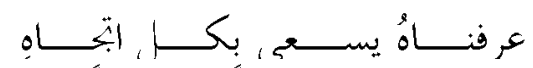

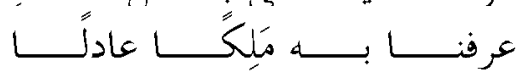

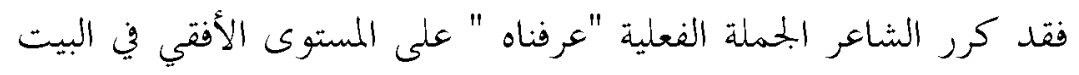

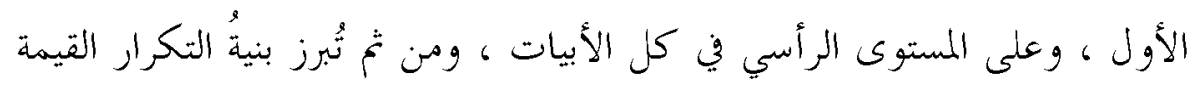

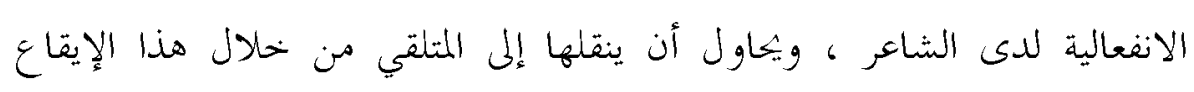

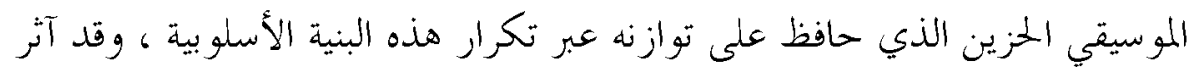

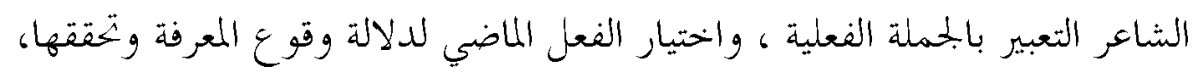


فلا يتطرق إليها الشك ولا يرتقي إليها الريب ، ومع ثبات المعرفة فإن المعارف تتجدد وتتغير ، ومن ثع عبر عن هذه المعارف بصيغة المضارعة هكذا : " عرفناه

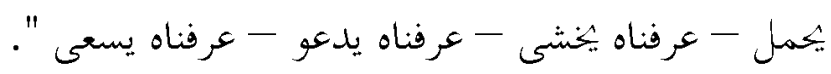
وفي هذا التحول عن صيغة الماضي عبر الجملة الثابتة المتكررة " عرفناه " إلى لئل صيغة المضارعة المتغيرة المتجددة إثارة لانفعال المتلقي ، وسرعة الانتقال به عن هذه أنه المعرفة الثابتة إلى ما تبثه صيغة المضارعة من أفعال متجددة تحمل دلالة استحضار

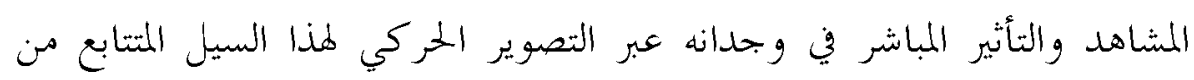

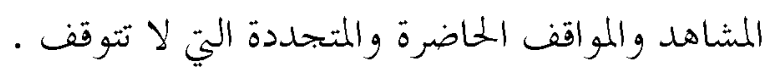

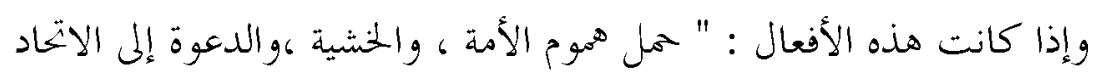

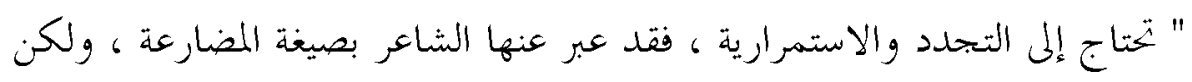

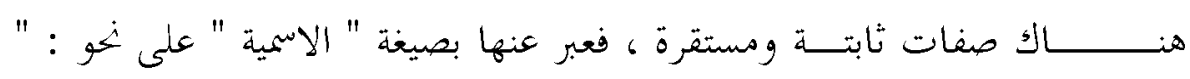

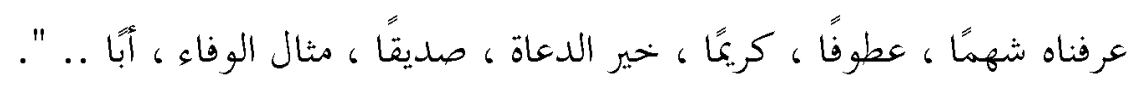
ومن تم فإن الأمر يرجع إلى مقدرة الشاعر في نظم الجملة ، وتوظيف الدلالة المناسبة التي يقتضيها السياق، وتتطلبها الصورة . r- ب تكرار شبه الجملة :

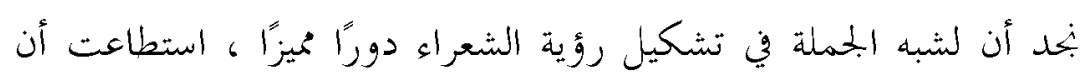

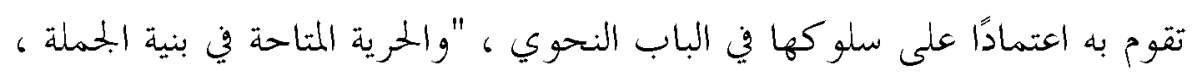

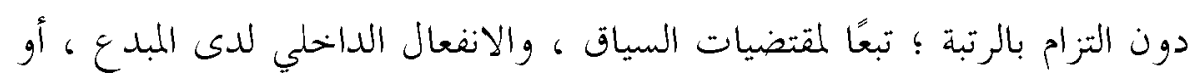

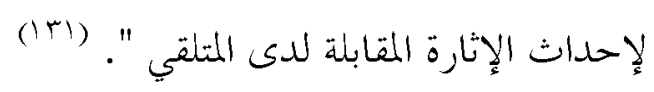

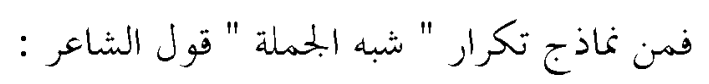

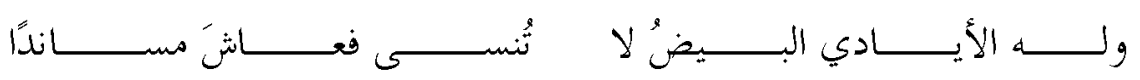

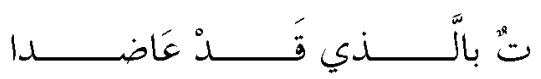

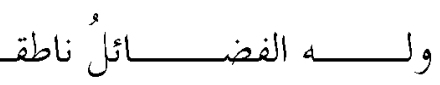
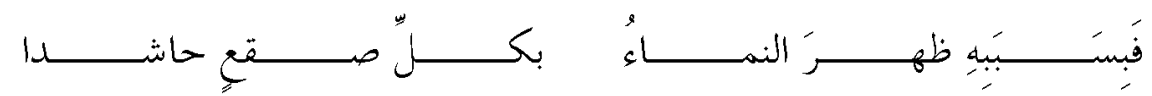


\section{ظـاهرة التكرار}

متماهـ

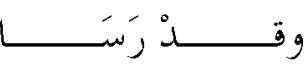

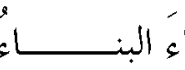

d

فيغضن

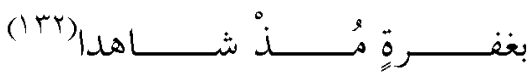

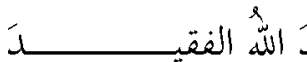

فتخمَ

كرر الشاعر شبه الجلملة " له " مرتين ، وظهرت دلالة التخصيص واضحة في

تقديم البلار والبرورر ، فالأيادي البيض اليت لا تنسى ، والفضائل الناطقات لا تكون إلا له ، وون ثم يعود إلى صيغة شبه الجملة ، فيجعلها ثخور الارتكاز الذي يبين عليه رؤيته ، من خالال دلالة " التخصيص " فيقول : " فبسببه ظهر النماء" "6 فلم يكن له الدور الأكبر في ظهور النماء فقط ، بل اختص و حده هذا الأمر 6

فلو لاه لتوقف النماء واختفى أثره .

ولنتأمل في هذا التوازن الموسيقي الذي أحدثه تكرار صيغة " شبه الململة " حيث يقول

$$
\text { فبسببه ظهر }
$$

191

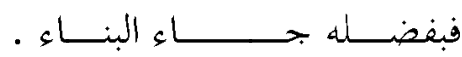

$\overline{3}$

إذن نلمح الارتكاز على دلالة التخصيص ، مع جودة الصياغة ، وتناست التشكيل الصوتي ، منا يساعد على وضوح الصورة وانغعال المتلقي ها ، ومن تم ينتقل إلى اللعاء للفتيد أن يتغمده الله برحمته . ويقول الشاعر

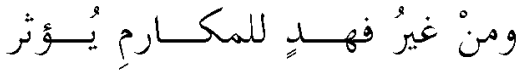

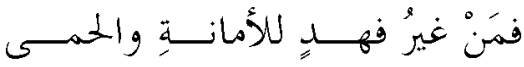

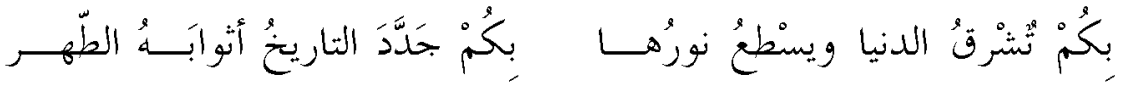

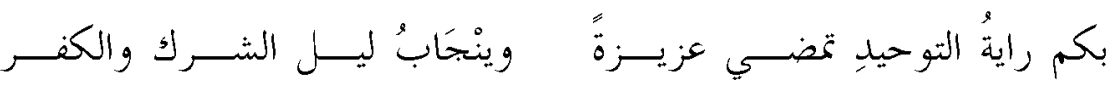

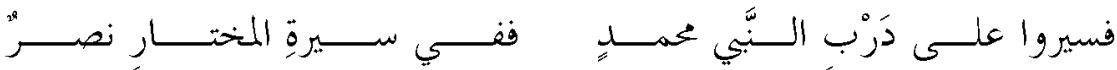
فنجد أن تقديم الجلار والمحرور قد أفاد التخصيص ، فإشراق الدنيا ، وإضغاء الجلدة على التاريخ ، واستمرارية راية التوحيد خفاقة ، وزوال ليل الشرك ، كل 
هذه الأفعال لا تكون إلا به ، إضافة إلى هذا التناسق الصوتي والتوازن الموسيقي الذي أحدثه تكرار شبه الجملة . وثمة إشارة تجذب انتباه المتأمل في " المراثي " خاصة في توظيف تكرار صيغة تحكة "شبه الجمملة" والارتكاز على دلالة التخصيص من خلال بنية " التقديم " ، وهي

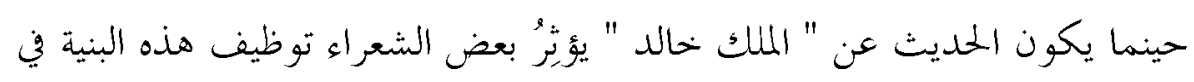

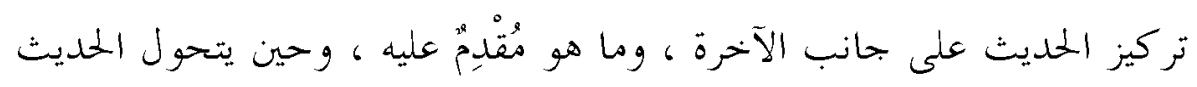
إلى "الملك فهد" ولي العهد ، يؤثرون توظيفها في تركيز الحديث على جانب الدنيا

$$
\text { وعمارها . و فمثلا يقول الشاعر : }
$$

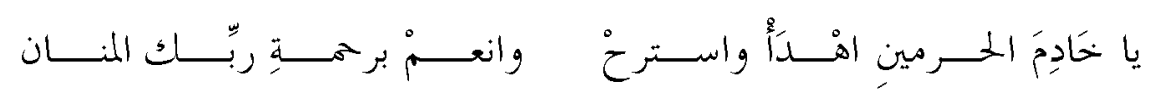

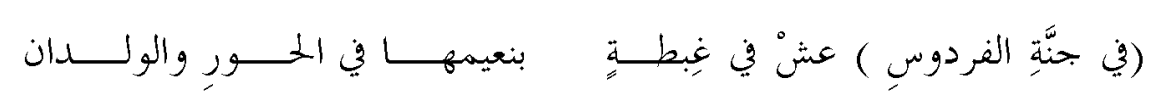

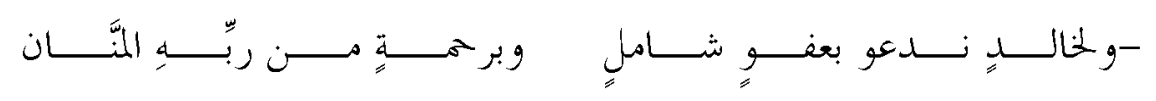

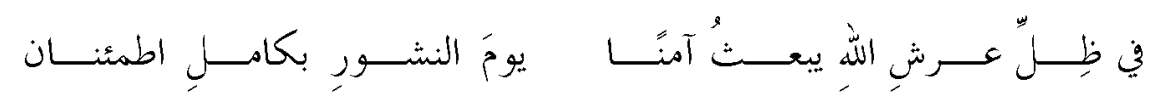

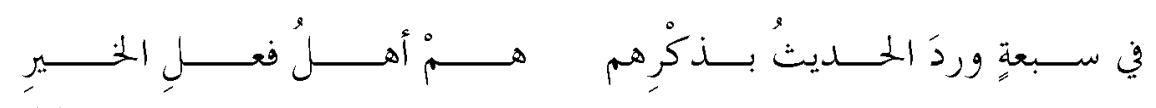
فالنداء في هذه الأبيات لخادم الحرمين الملك خالد - رحمه الله - وقد تبعه

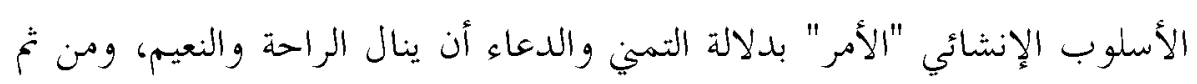

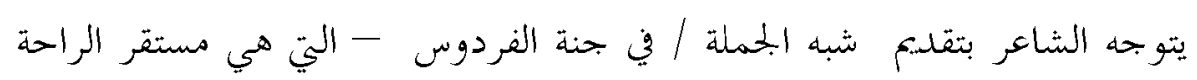
الحقيقية - على العامل / عش . ثم يعود إلى تقلديم ( شبه الجملة ) ( لخالد ) على العامل ( ندعو ) ؛ للدلالة

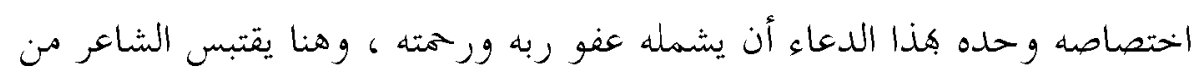
أحاديث البي - صلى اللّ عليه وسلم - حديث السبعة الذين يظلهم الله في ظله وسله

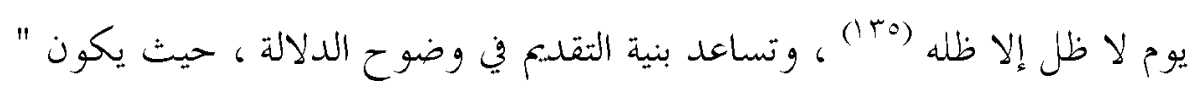




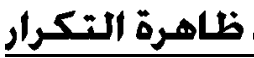

في ظل عرش الله " / يبعث ، ودلالة الحال ( آنًاً ) ، ويعود فيؤكد رؤيته من

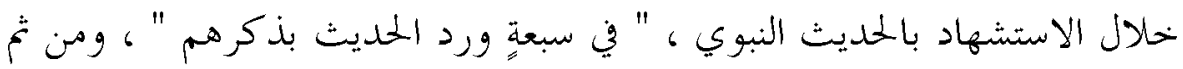

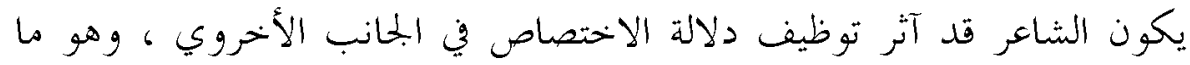

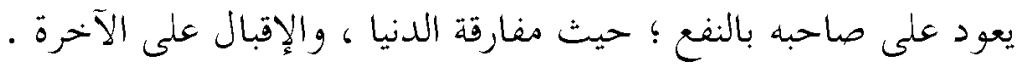
ويقول الشاعر :

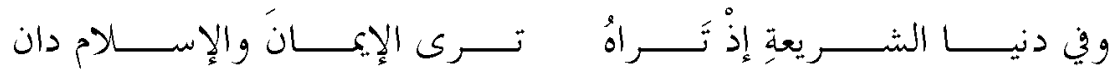

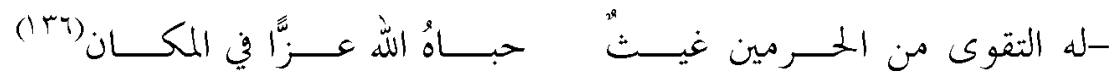

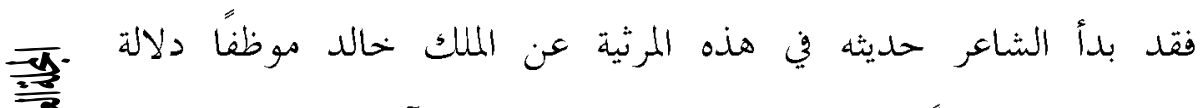

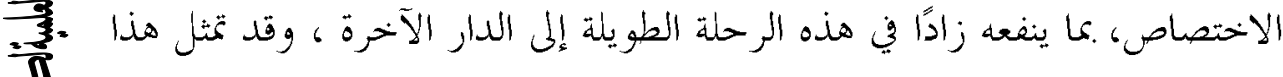

焉.

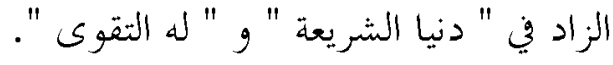

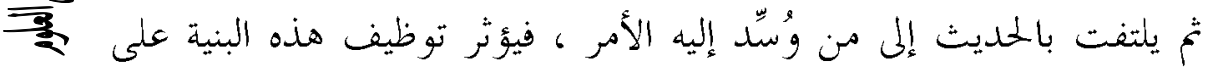

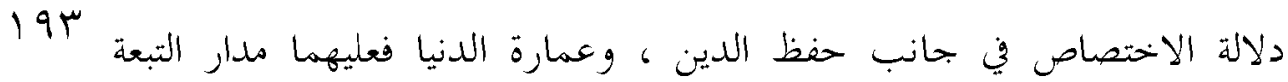

$\overline{3}$ والمسؤولية ، فيقول :

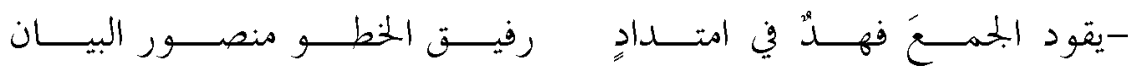

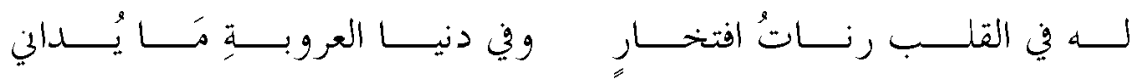

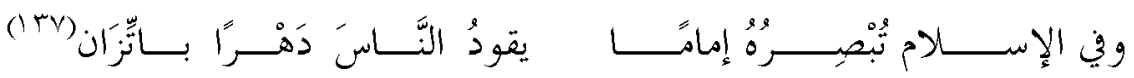

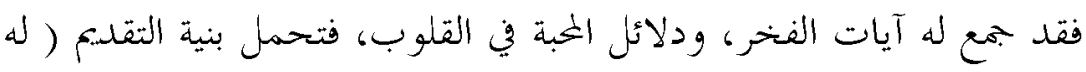

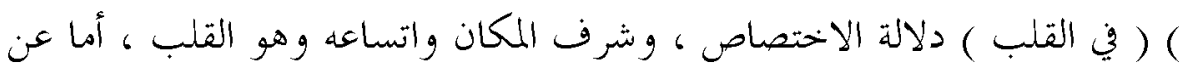

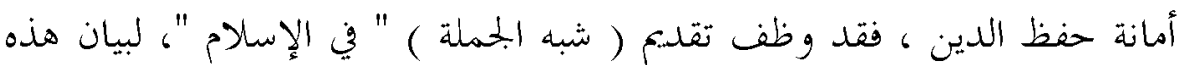

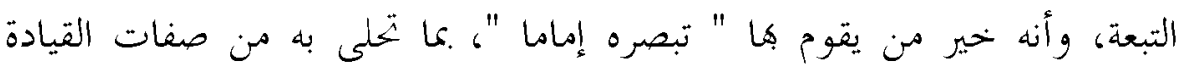

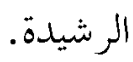
وأما عن عمارة الدنيا ، فيقول : 


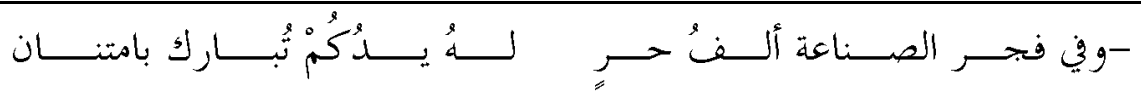

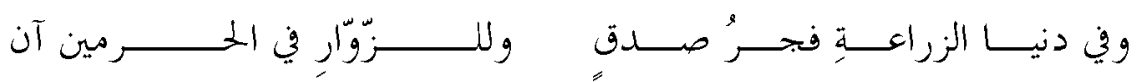

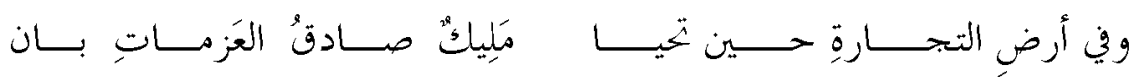

فقد جمع جوانب عمارة الدنيا في بمالات: ( الصناعة ، والزراعة ، والتجارة

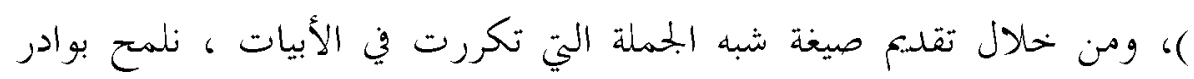

النوضة وصدق العزم في استمرارية البناء والعطاء .

ب- ومن نماذج تكرار شطر البيت قول الشاعر :

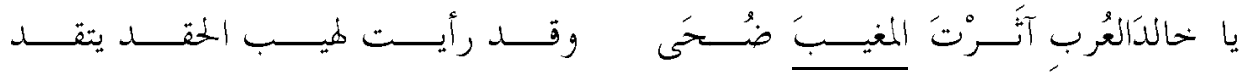

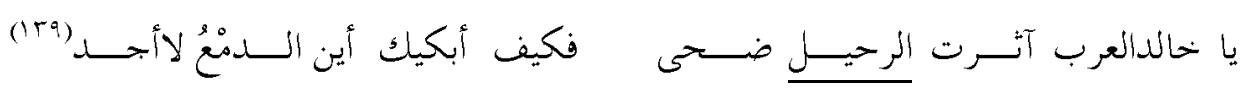

فقد اختار الشاعر لفظ " المغيب " ؛ لأن الواقع يشهد بذلك :

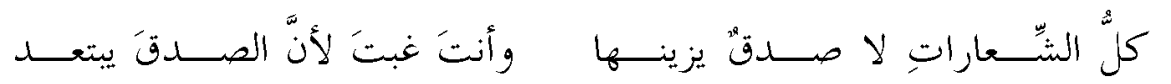

: ثم كانت النداءات المتتابعة :

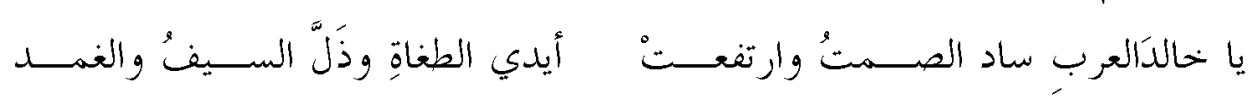

ولذلك كان التساؤل الذي يكشف أبعاد المأساة :

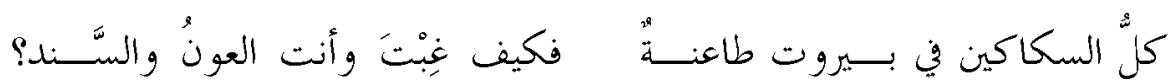

ولكنها الحقيقة الواضحة والحكمة الباقية ، والعود الرشيد إلى التسليم التام ، والرضا بالقضاء :

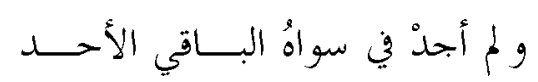

$$
\text { ومن ثم يكون التطور الدلالي في بنية التركيب : }
$$

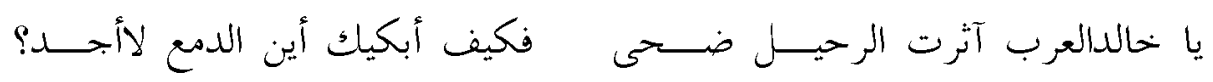
فكرر التركيب نفسه ، مع إحلال لفظ " الرحيل " في بنية التركيب بدلً من 


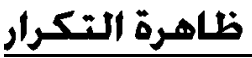

لفظ " المغيب " ، ولذلك كان الإقرار بالرحيل ، والتسليم للقضاء ، فكان

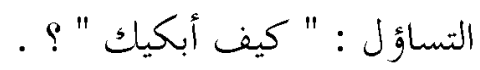
ع- ومن نماذج تكرار السطر الشعري الذي جعله الشاعر مرتكزًا دلاليًا

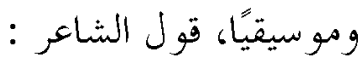

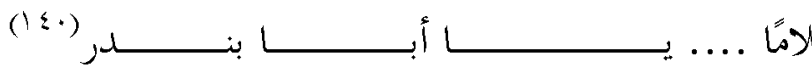

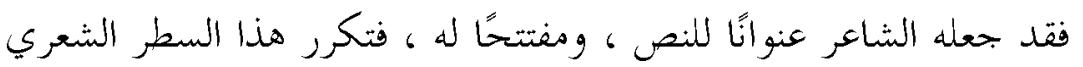

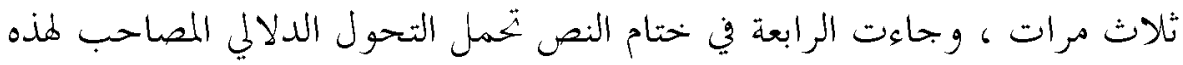

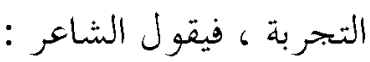
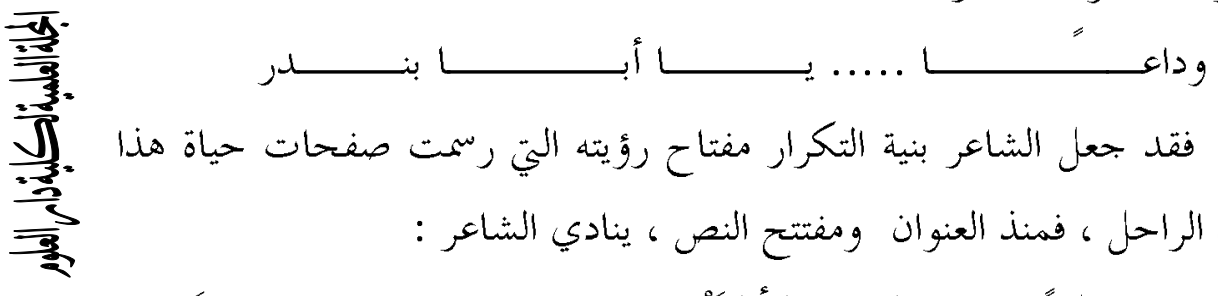

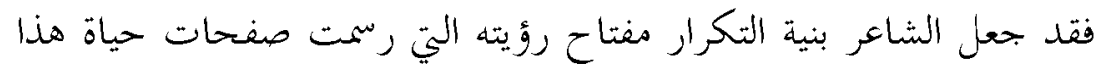

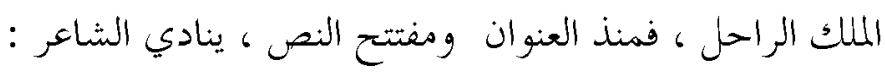

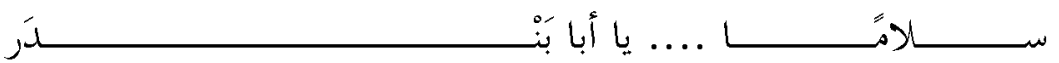
فقد طال الانتظار ، والشوق قد أَرَّقَ الأجفان ، وإذا .مشهد الموت يهز

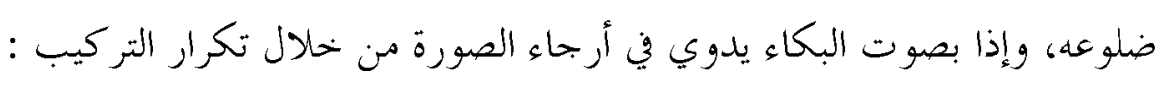

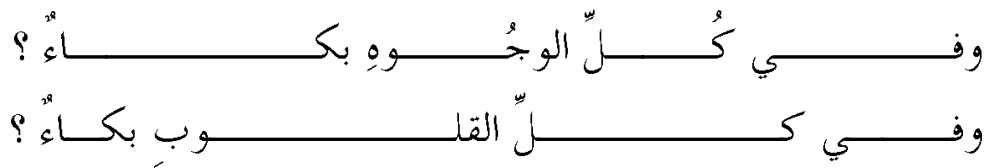

وإلى هنا يكرر : ســلامًا ... يا أبا بندر ؛ لأنه ما زالت في النفس حيرة إزاء الموقف ، يكشف عن أبعاد هذه الحيرة تكرار أسلوب الاستفهام :

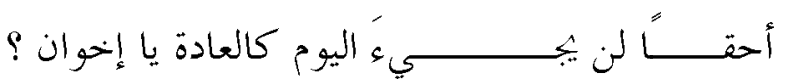

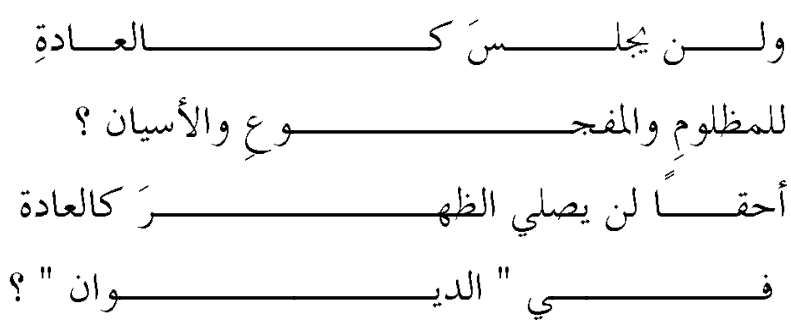




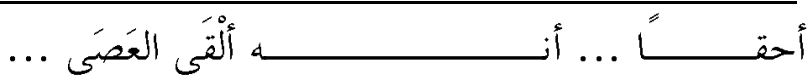

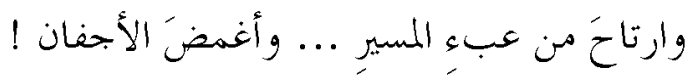

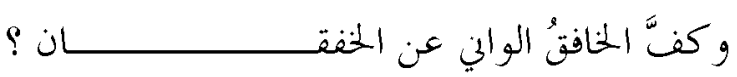

- وهنا تأتي الإجابة البليغة :

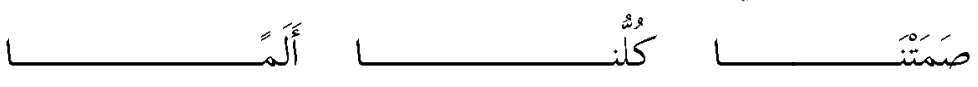

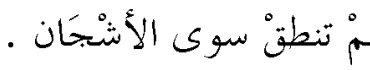

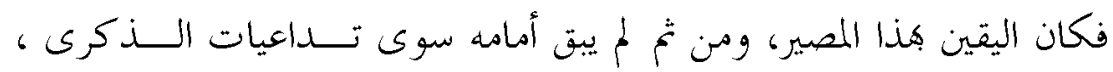

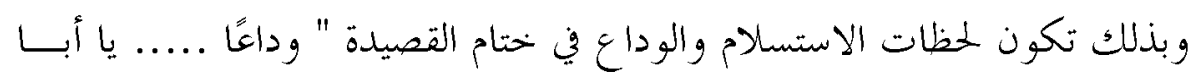

$$
\text { بندر "." الأساليب الإنشائية : }
$$

ساعدت بنية الأساليب الإنشائية في تشكيل رؤية الشعراء ؛ لأن " ظهور

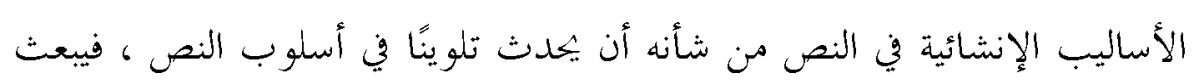
فيه الجددة والحيوية ، كما تعد هذه الأساليب ذات تأثير بالغ على المتلقي تدفعه نيو المشاركة في ( فعل القول ) الذي يصدر عن الشاعر فيقف متلقيًا لأوامره

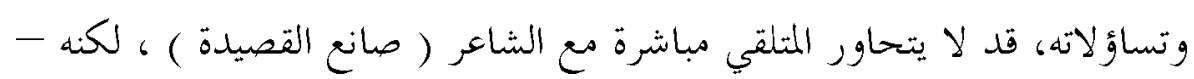

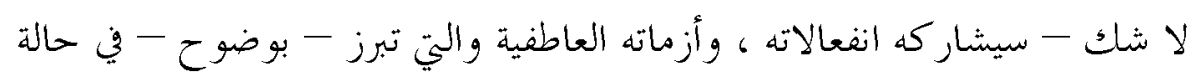
الأسلوب الإنشائي، وهنا يؤكد الأسلوب الإنشائي - مرة أخرى - الطابع التخاطبي ( الخاص ) للغة الشعرية ، بمعنى حضور مخاطب حقيقي أو محتمل في

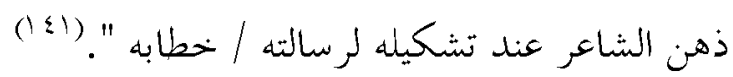
وتتمثل الأساليب الإنشائية في :

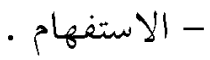
- النداء أ) الاستغهام : 


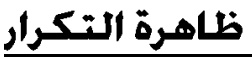

يتقدم الاستفهام أساليب الإنشاء الطبي بنية فاعلة في إنتاج الدلالة في

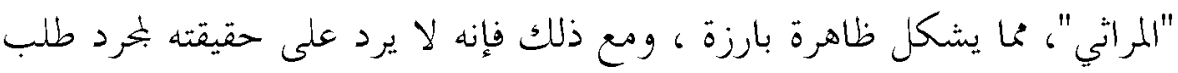

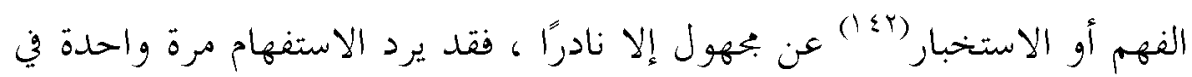
القصيدة ، كقول الشاعر :

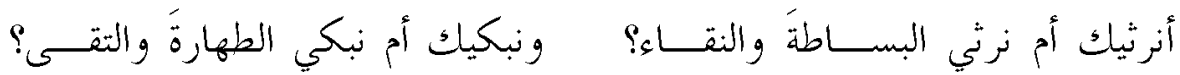

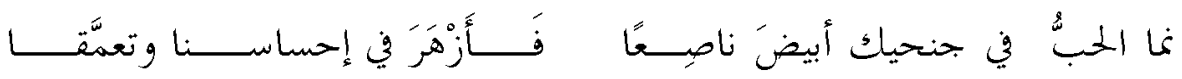

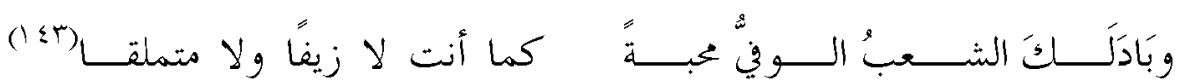

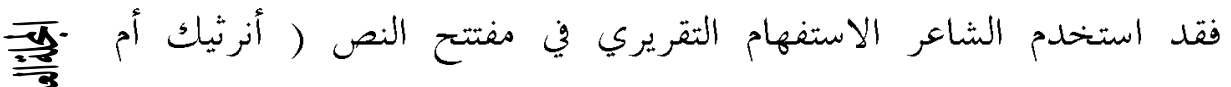

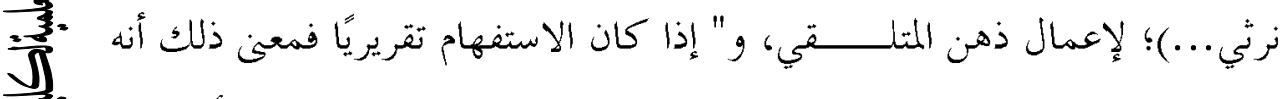

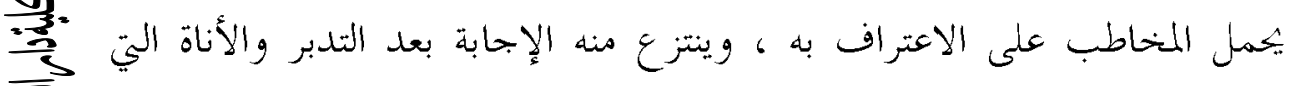

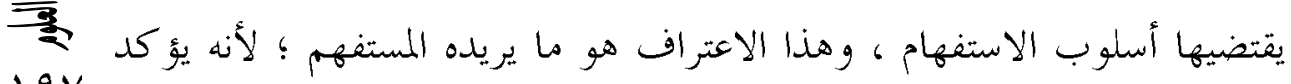
$19 V$

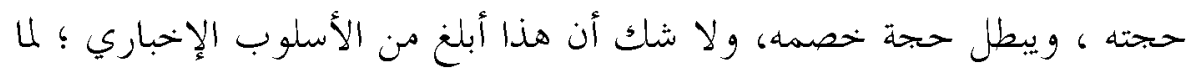

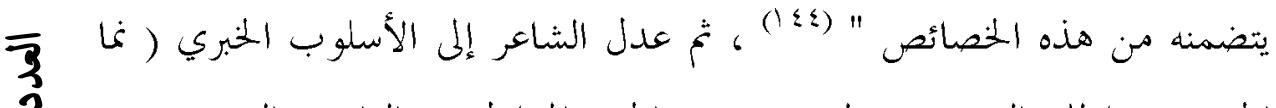

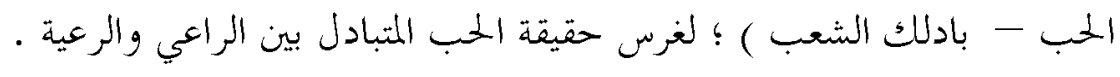

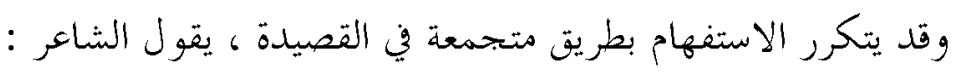

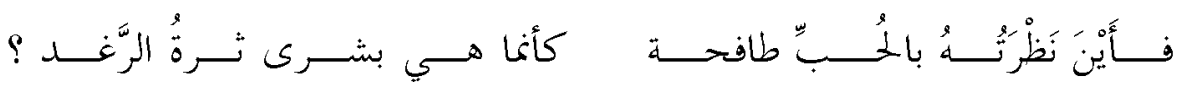

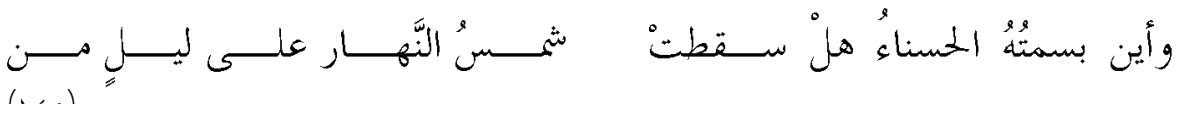

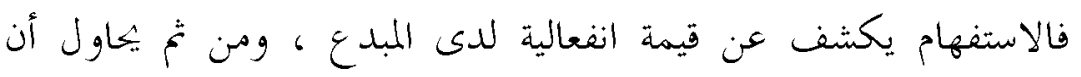

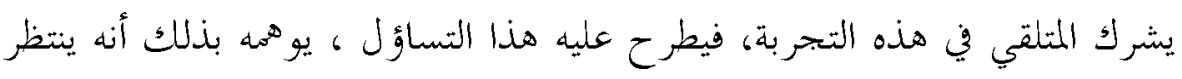

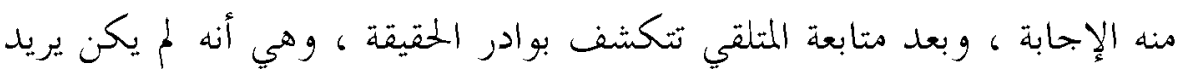

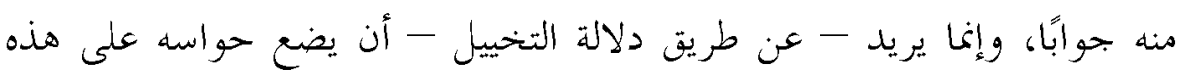

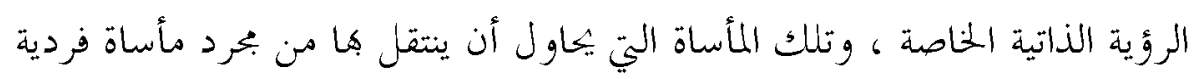


إلى مأساة كونية عامة تمس كل إنسان من قريب ، و لا يخفى ما يجدثه الاستفهام

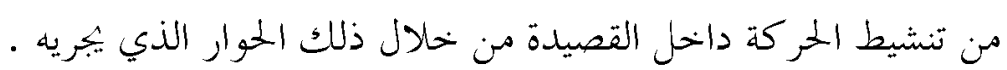
إذ يسهم الاستفهام في " فتح البحال الدلالي وشحنه بقوة إيحائية ، تستدرج القارئ إلى إكمال النص ، وتدفعه إلى البحث عن عناصر الغياب من نواقص وإlجابات "(i)

ومن ثم يعوّل الشاعر على تكرار بنية الاستفهام في القصيدة مرة أخرى ، فيتول

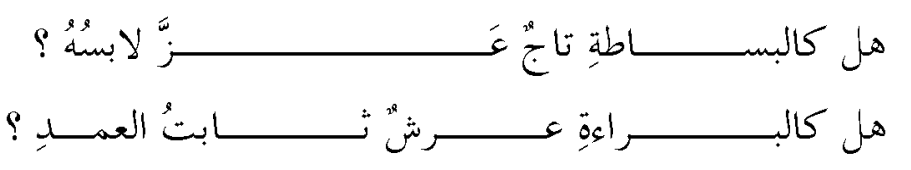

فالاستفهام لمُيُرجَ من ورائه إجابة ، وإنما يكمل المخاطب إلى توجيه كل

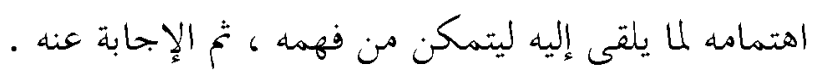
وقد يقوم الشاعر بتكرار بنية الاستفهام عبر فترات متباعدة في النص الشعري ، ولكنها في كل مرة تحمل بعلًا جديًا من أبعاد التجربة ، و وتضيف دلالة مغايرة في إطار البناء الدلالي للنص ، فقد كرر الشاعر غازي القصيي بنية الاستفهام :

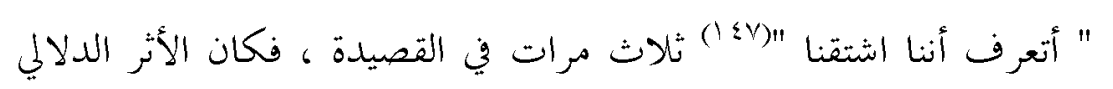

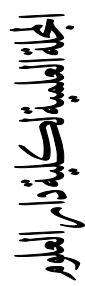

المترتب على الاستفهام :

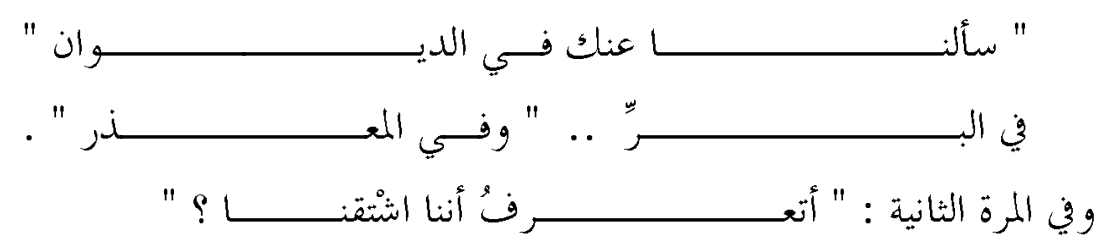

فبدأ الإحساس بالأزمة يتصاعد، والشعور بكرارة الفراق يخيم على أبعاد

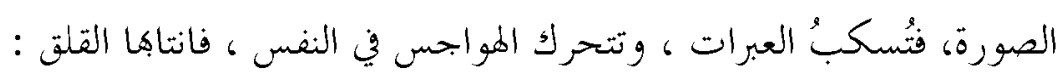

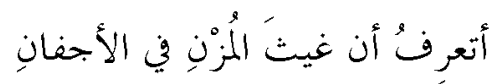

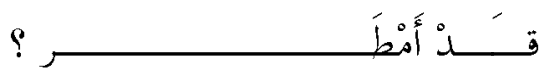




\section{ظاهرة التكرار}

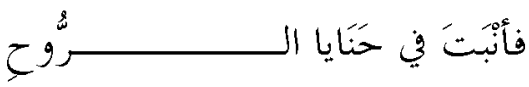

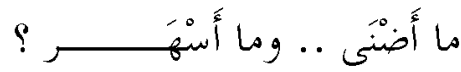

فتكشّفت الحقيقة ، و كانت المواساة وماولة التّصبر استعادة الذكريات ؛

ليكون فيها السلوى

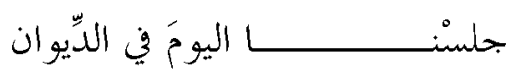

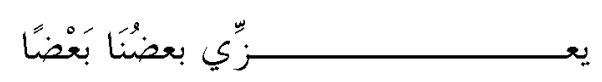

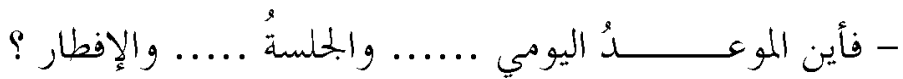

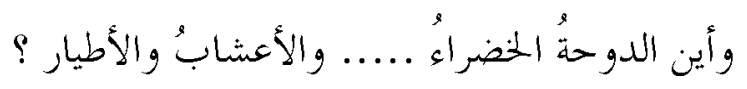

ويقول الشاعر :

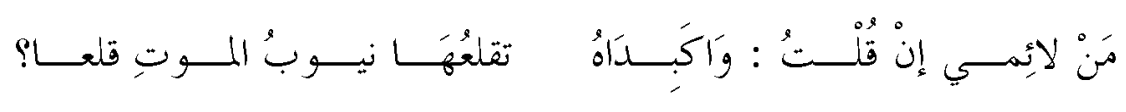

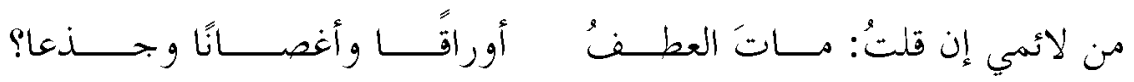

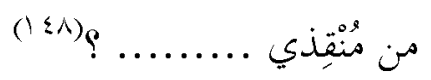

تكشف بنية الاستفهام عن عمق الخنة التي ألمت بالمبدع ، ومن ثم يبدو

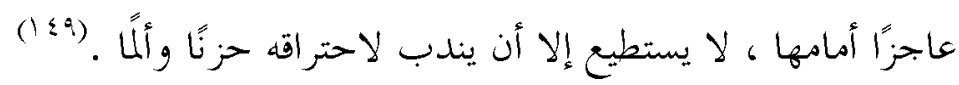

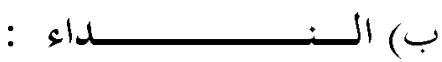

النداء أسلوب بـ إنشائي يعتمد على الأداة اليتي تدل على جملة " أدعــــــ "

مع إفادة الدلالة على هذا المعنى ، ولا يعين هذا أن نسوي بين هملة أدعو والنداء بالأداة، فني الثانية مع ملاعمة غرض النداء فإها تحمل قيمة صوتية لها أثرها في إثارة انفعال المتلقي " وحين تتخلص بنية النداء من دلالة الإقبال فإها تنتج دلالات سياقية متعددة، يتحرك معظمها في نطاق الوظيفة الانفعالية ، ويتحرك بعضها في نطاق الوظيفة الإفهامية ". (10.)

بيد أنه قد ورد النداء في " المراثي " مستغنيًا عن التنبية ، فليس المنادى طرفًا 
ثانيًا يتبادل معه الموار ، وإنما المتلقي هو موضع الهتمام المبدع من خلال أسلوب

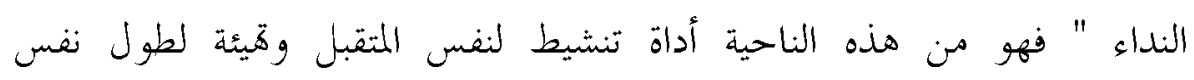
الشاعر" (101)

والمنادى في " المراتي " / المتلقي الخاص ، هو معور آلام الذات المبدعة ،

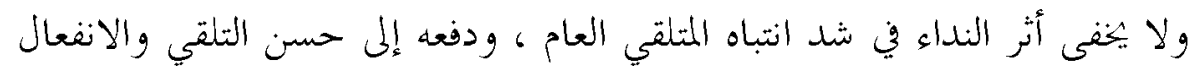

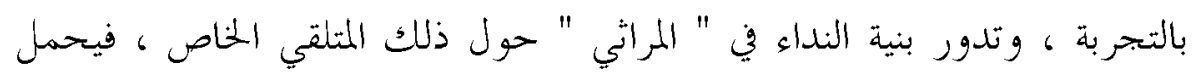
النداء قيمة صوتية تخفف من آلام الشاعر، وتنقل معاناته إلى المتلقي العام ليشاركه

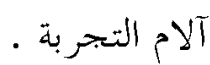

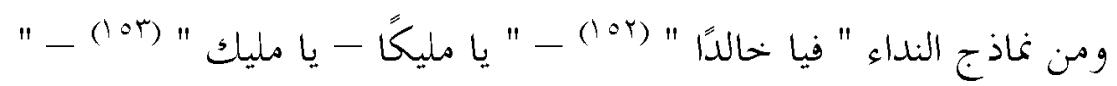

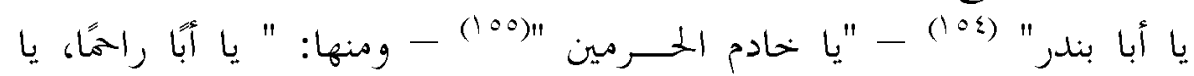

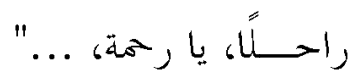
وقد يستهل الشاعر قصيدته بالنداء مثل :

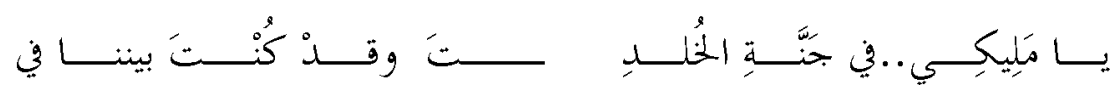

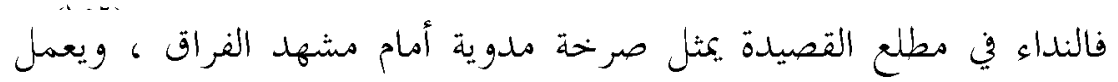

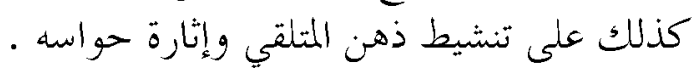

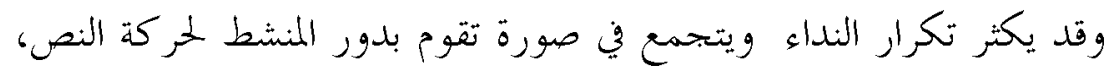
وإثارة حالة النواح الداخلي لدى المبدع، والكشف عن مدى تعلقه بالمنادى والانشغال به ، يقول الشاعر :

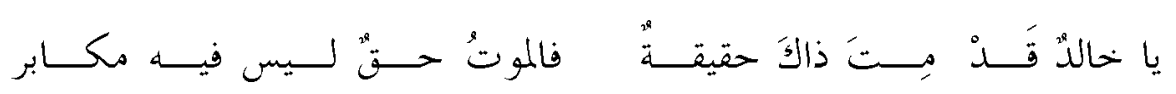

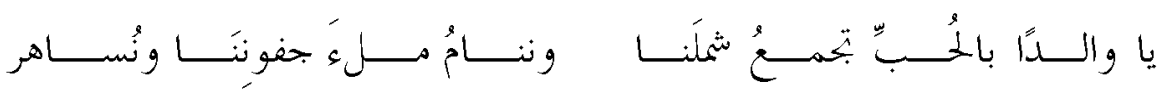

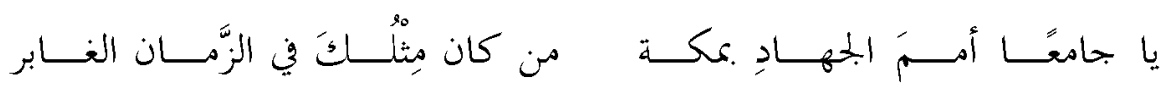

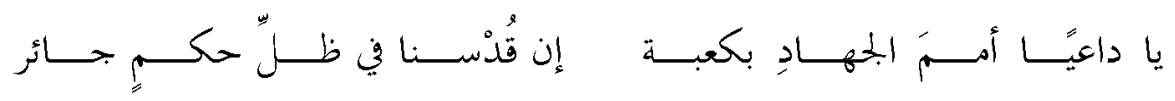

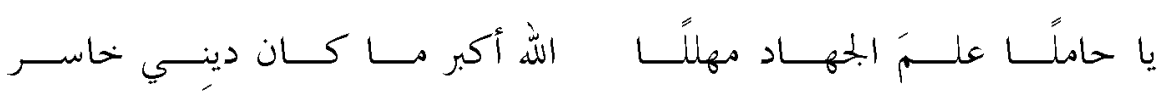




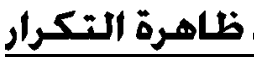

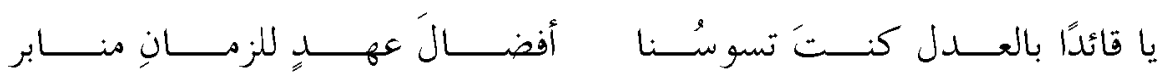

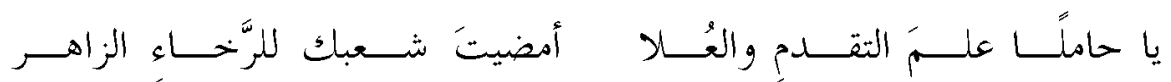

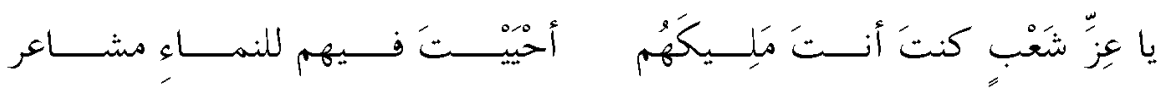

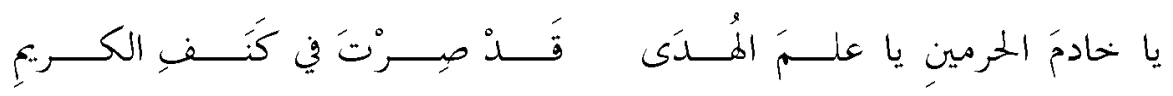

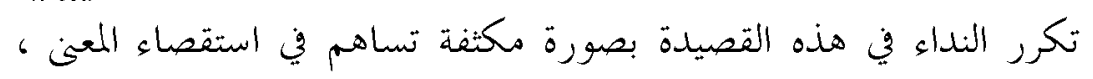
وإعلاء قيمة المنادى ، والكشف عن صفاته المميزة .

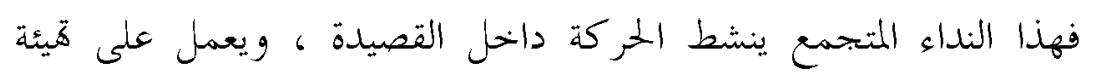

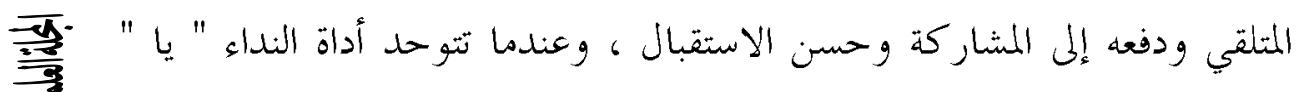

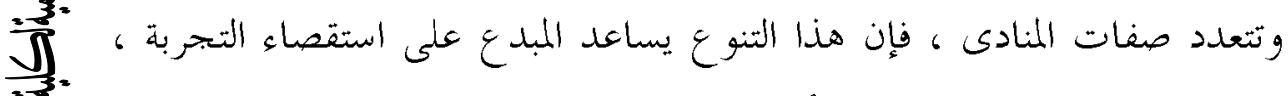

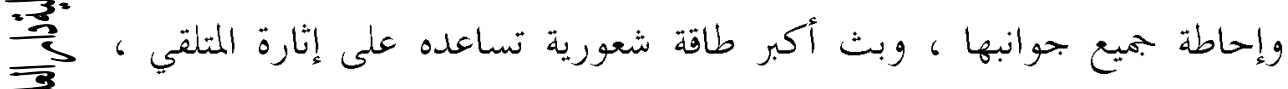

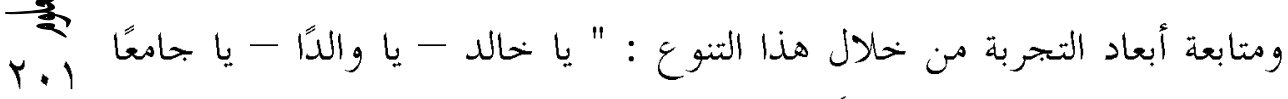

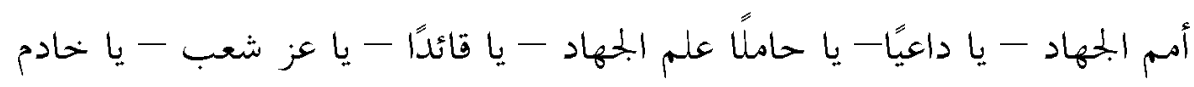

$$
\text { الحرمين ..." الحم الحهاد }
$$

فقد بدأ بالمنادى العلم "يا خالد" ثم تدرج في صغاته التي تتنامى مع بناء

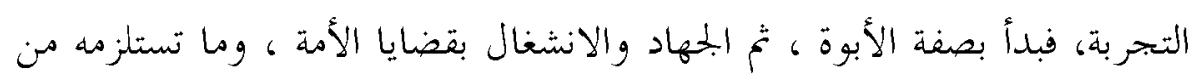

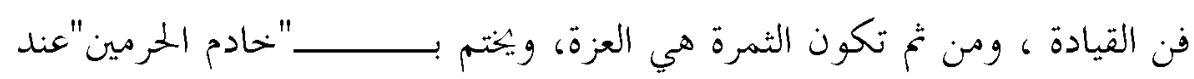
التحول إلى جوار الكريع.

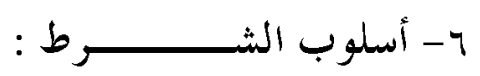

يعد تكرار أسلوب الشرط من البنى الفاعلة في تشكيل الرؤية وإنتاج

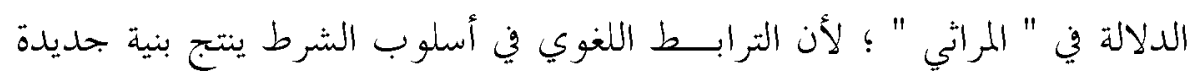

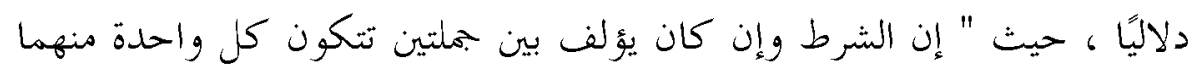

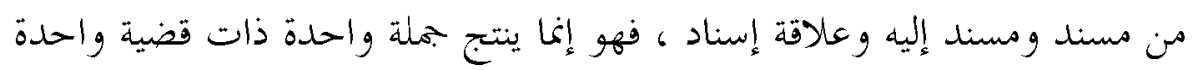


، لا يتسنى التعبير عنها بأحد جــئي الجملة الشرطية ( فعل الشرط - جوابه ) ،

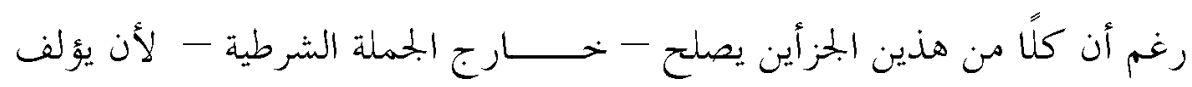

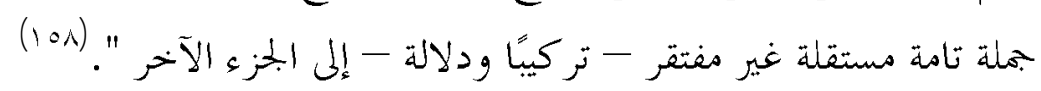
ويؤكد ابسن جني على هذا الترابط المككم بين الجملتين ، واحتياج كل منهما للآخر فيقــول : " ومنها أن بعض الجمل قد تحتاج إلى جملة ثانية احتياج

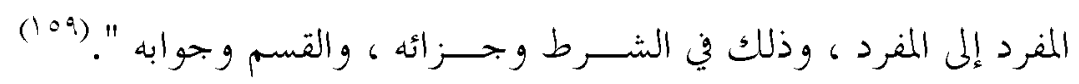

$$
\text { يقول الشاعر : }
$$

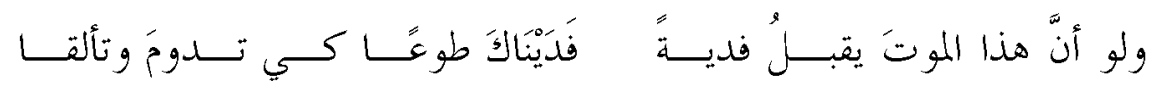

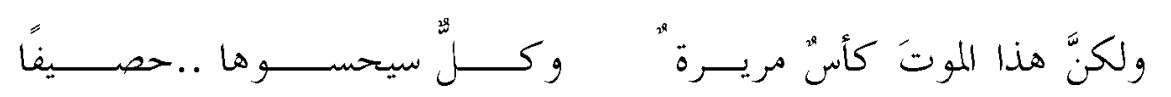
ويقول الشاعر :

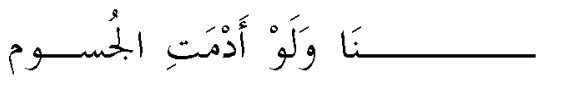

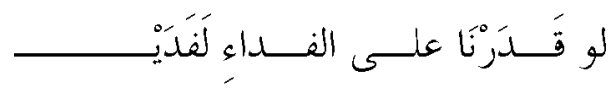
ـتنيع Y أنَ

فقد تكرر أسلوب الشرط عند الشاعرينهع تصرف الشاعر الأول في بنية

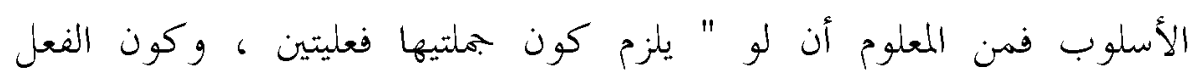

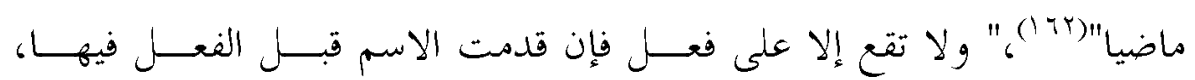
كان على فعل مضمر ". (IT)

ومن ثم تكون " لو " في المثال الأول قد دخلت على فعل مضمر يفسره

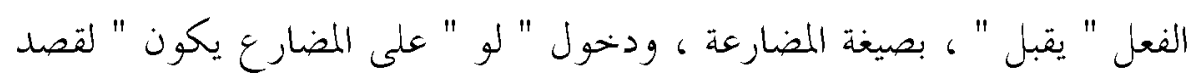

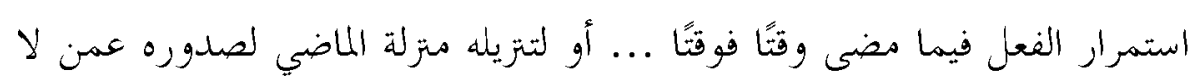

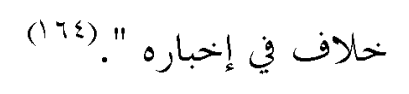
ومن المعلوم كذلك أن " لو" للشرط في الماضي مع القطع بانتفاء الشرط،"

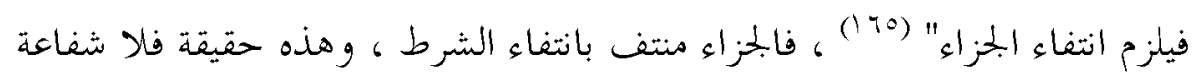




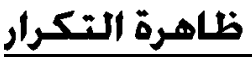

في الموت ، ومن ثم كان التعبير عن هذه الحقيقة في الأبيات التي تلي أسلوب

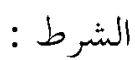

- فني النص الأول:ولكن هذا الموت كأس مريرة وكل سيحسوها .....

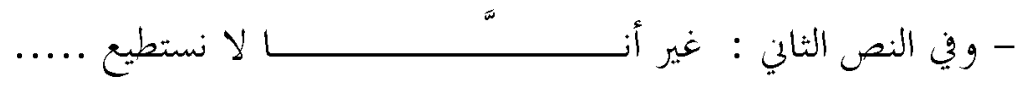

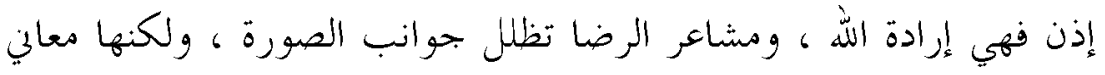

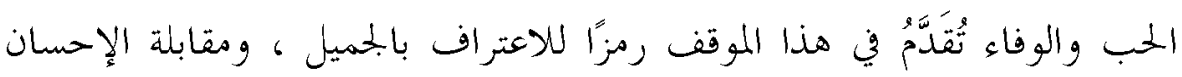
بالإحسان.

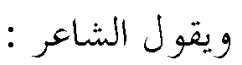

矛

شعبُ الجزيـــرةِ صــارمًا مصــقولا

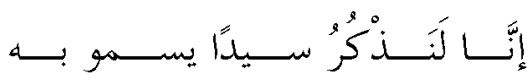

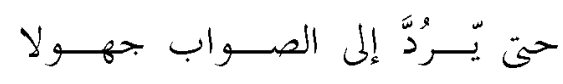

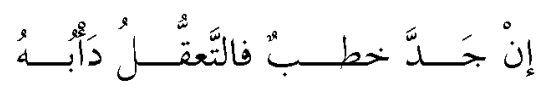

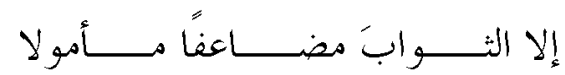

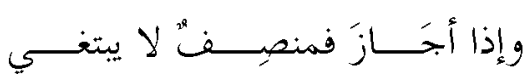

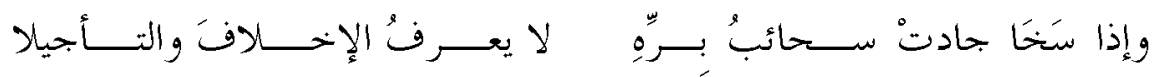

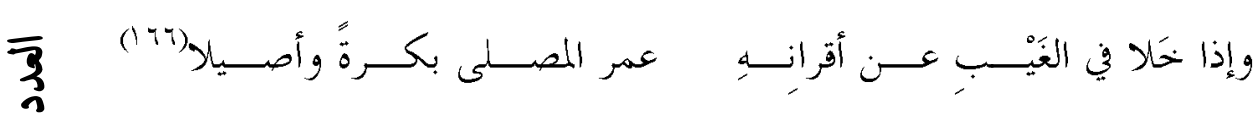

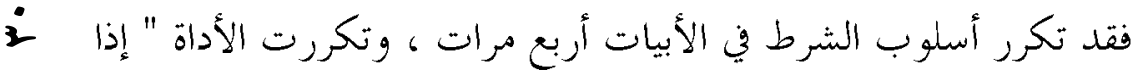

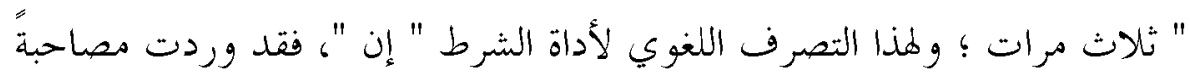

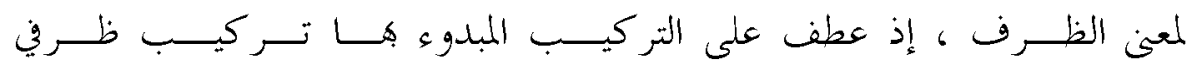

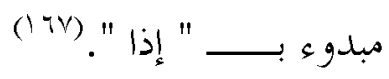

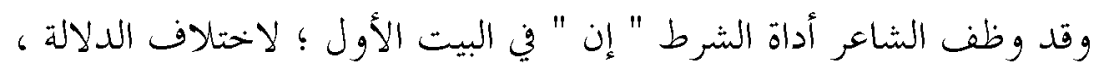

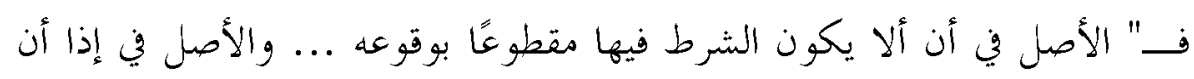

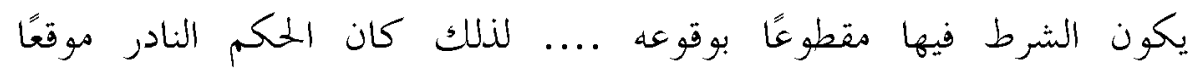

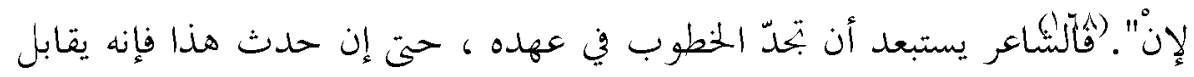

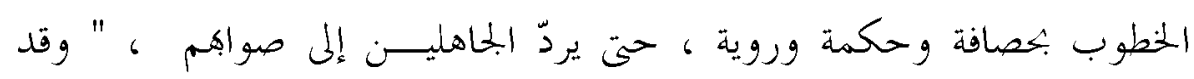


تستعمل إنْ في مقام القطع بوقوع الشرط لنكتة: كالتجاهل .."(19 )، فيرى الشاعر أن الابتلاء بالدواهي والخطوب طبيعة الحياة،فهي حادثة لا معالة، ولكن توظيف"إن" هنا لتجاهل هذه الخطوب كأذا لم تكن، ومن ثم يسهل التعامل معها، ومعالجتها، ومثو آثارها.

وفي الجلانب الآخر المتصل بالمرثي استخْْدَمَ " إذا " لدلالة أن الشرط فيها

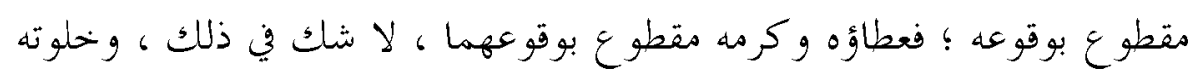

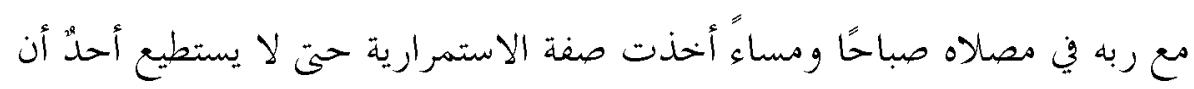
ينكر ها

ونلاحظ اقتران جواب الشرط بالفاء في البيتين الأول والثاني ، وما لهذا

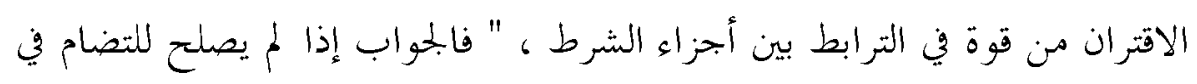

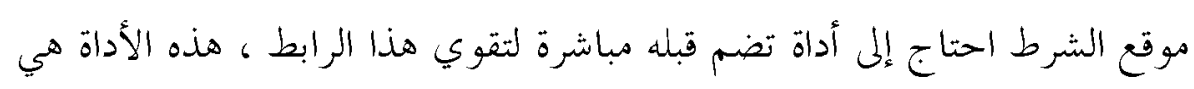

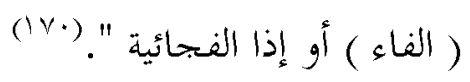

وبذلك فقد تناولت في هذا المبحث دراسة ظاهرة التكرار التركيي من إن التهائ خلال : تكرار( الجملة ، وشبه الجملة ، و شطر البيت ، والسطر الشعري )،

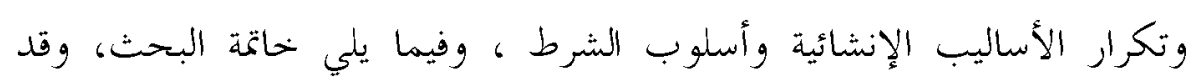

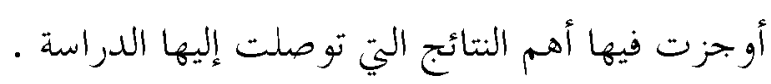

و بعد هذه المعايشة وظاهرة التكرار في مراثي الملك خالد بن عبد العزيز -

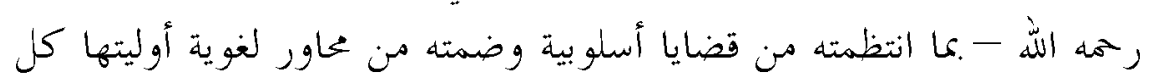

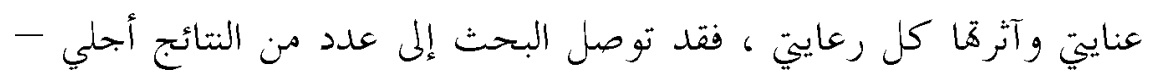

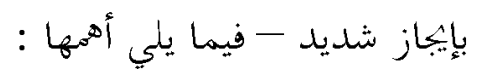

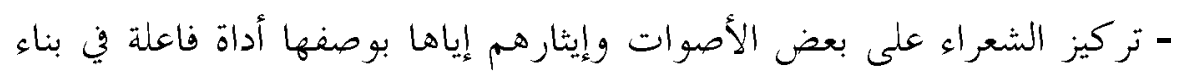
النص الشعري ، وقد استطلاع بعض الشعراء - عن طريق بتحانس التشكيل 


\section{طاهرة التكرار}

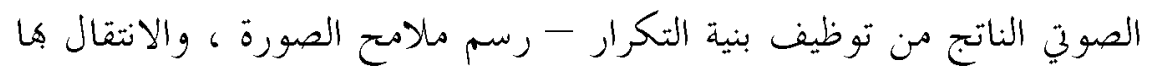
من حيز الفردية إلى نطاق التجربة الإنسانية العامة .

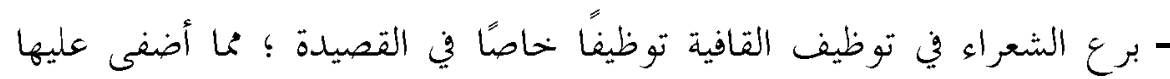

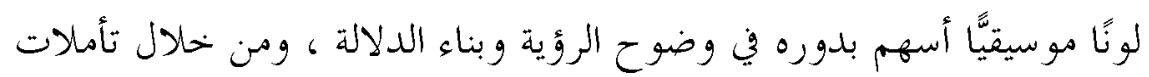

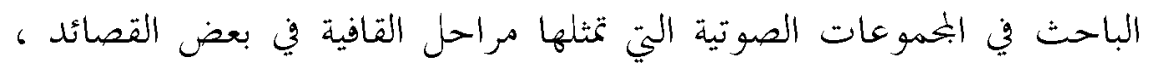

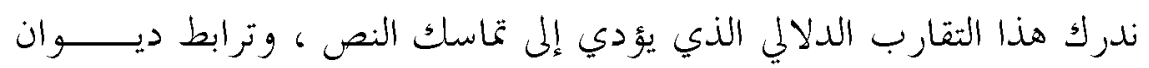

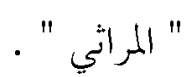

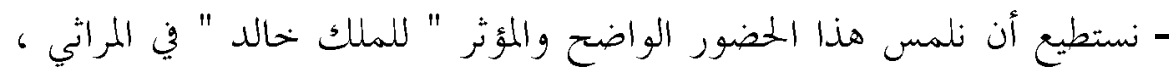

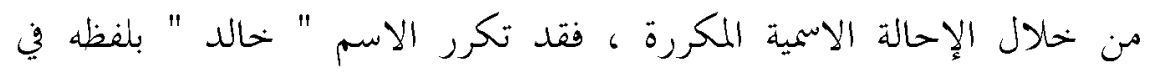

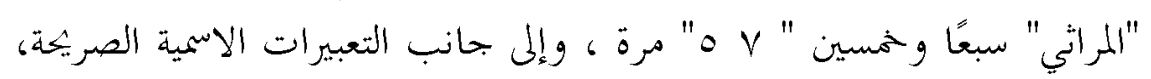

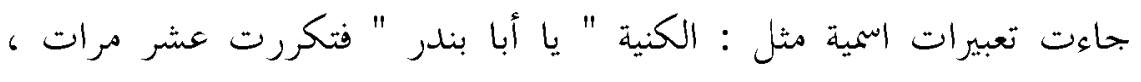

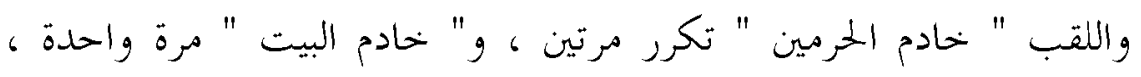

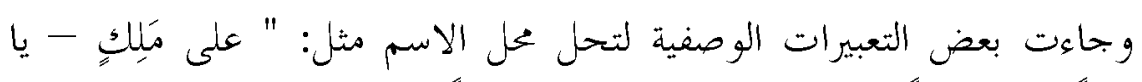

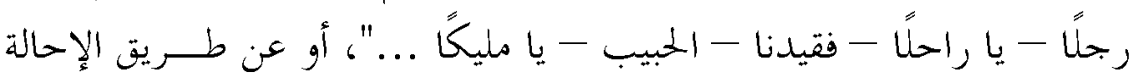

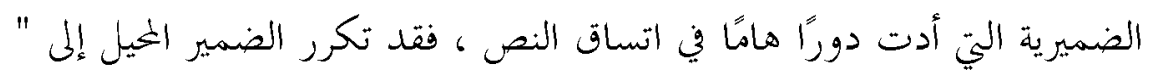

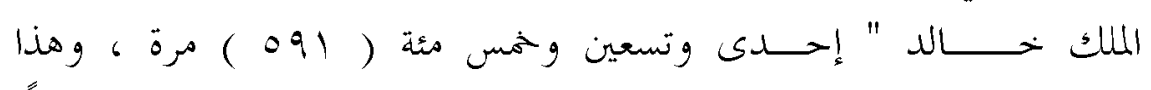

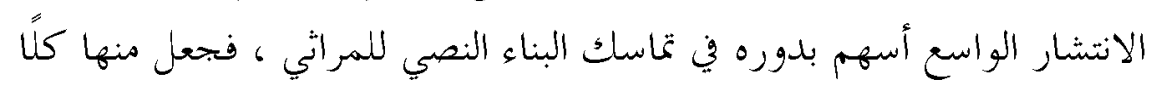

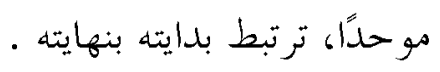

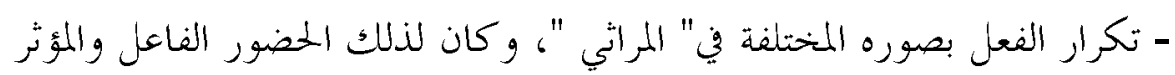

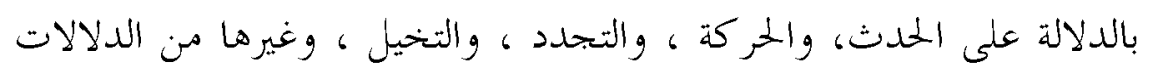

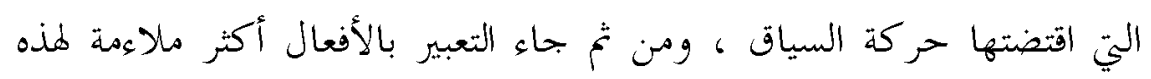

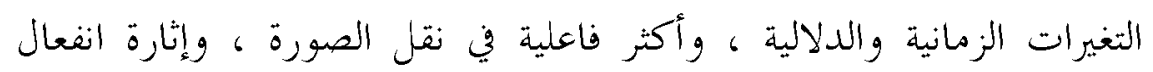
المتنقي لمشار كة الشعراء في هذه المعاناة .

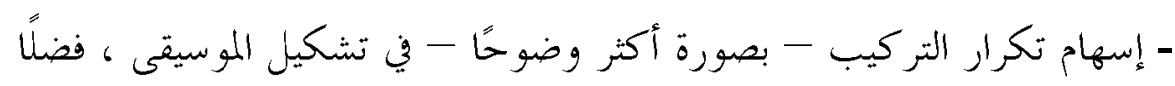
عن إنتاج دلالة النص ، بما يثيره من قيم انفعالية ، ودوافع نفسية. 
- ساعدت بنية الأساليب الإنشائية في تشكيل رؤية الشعراء ، وقد تقدمها

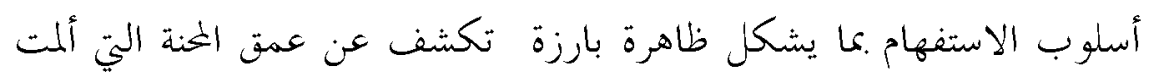

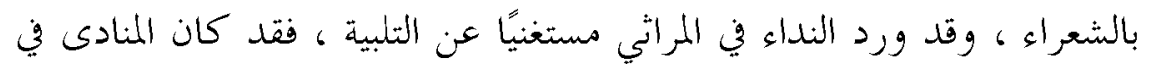

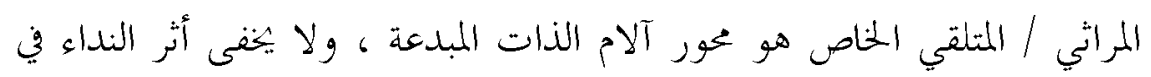

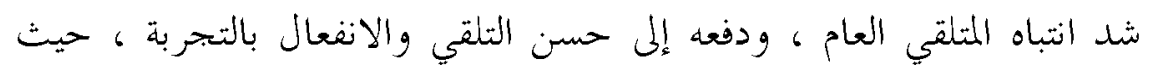

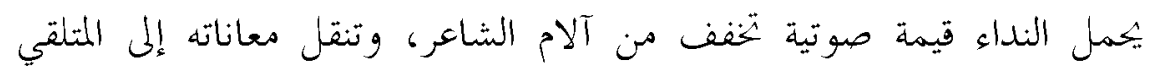

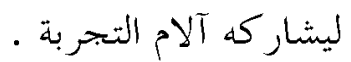

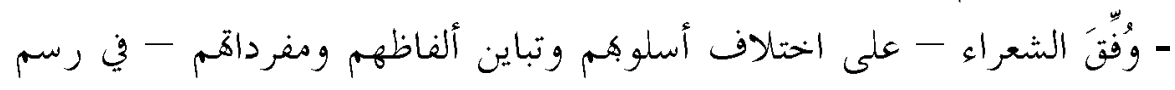

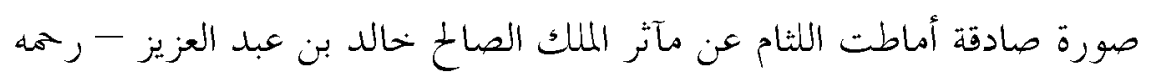

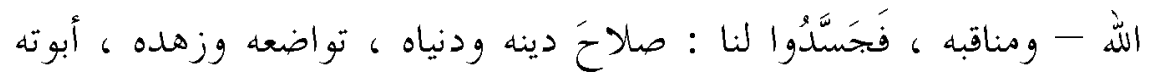

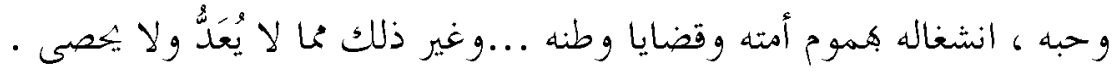

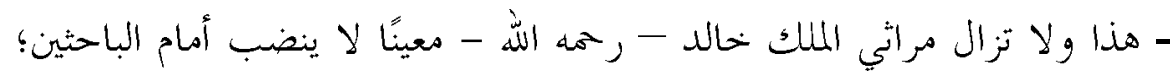

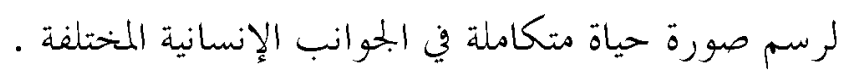

\section{قائهة الميسادو والمواجع$$
\text { : المصادر }
$$

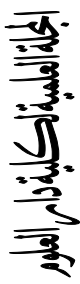

$T \cdot T$

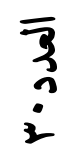

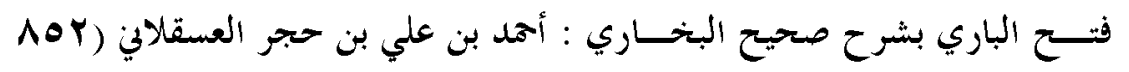

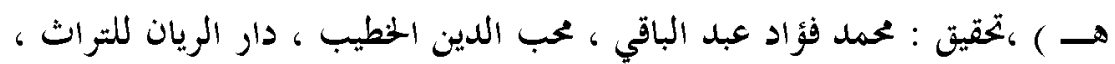

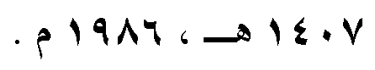

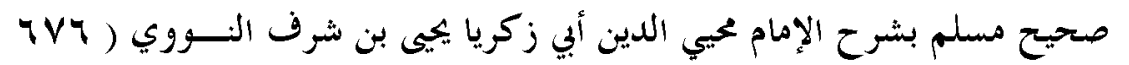

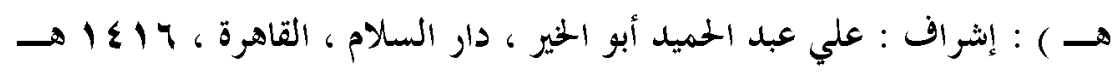

. 1997 ،

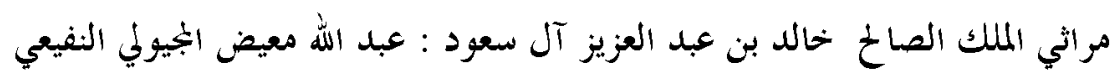

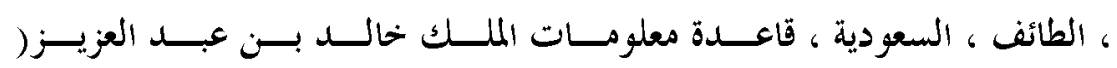
. ( ) (11.90\%).r

$\underline{: ~ ا ل م ر ا ج ع ~}$ 


\section{ظاهرة التكرار}

إبداع الدلالة في الشعر الجاهلي مدخل لغوي أسلوبي : د.محمد العبد ، دار المعارف الفرار

. ) 911

الاتساق والانسجام في سورة الكهف : مذكرة مقدمة لنيل شهادة الماجستير، إعداد:

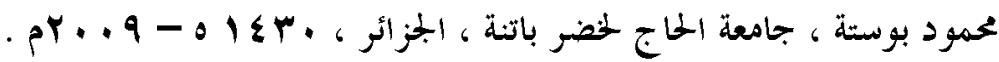

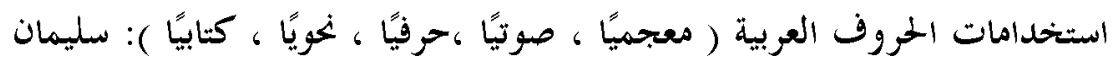

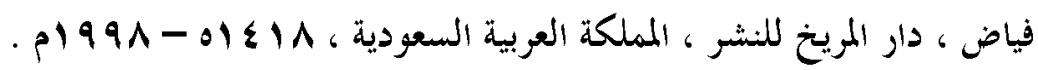

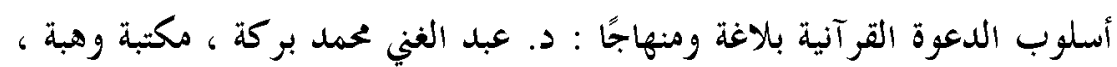

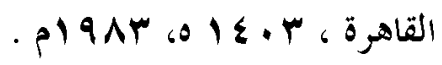

أصوات اللغة العربية ، دراسة نظرية وتطبيقية : د. محمد حسن جبـل هلمل ، التركـي

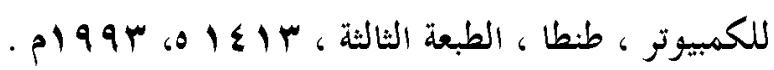

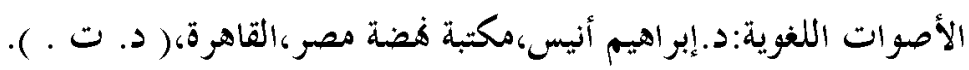

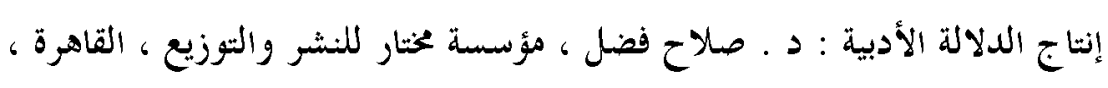
. plaAv $r \cdot v$

الإيضاح في علوم البلاغة : الحطيب القزويني (VPq هـ) ، شرح وتعليق وتنقيح :

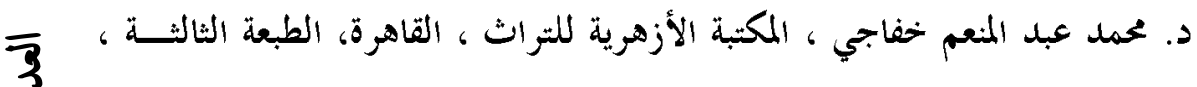

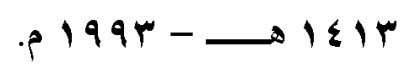

بلاغة النكرار في مراثي الحنساء: أ ـ مليكة يوراوي، جامعة محمد خيضر يسكرة -

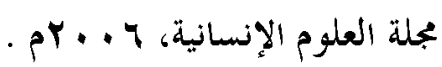
بناء الأسلوب في شعر الحداثة التكوين البديعي : د. محمد عبد المطلب، دار المعارف

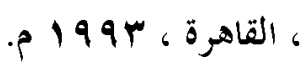
البنى الأسلوبية دراسة في " أنشودة المطر " للسياب : د. حسين ناظم ، المركز الثقافي

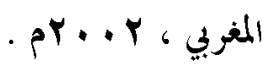

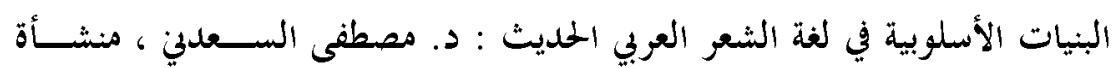

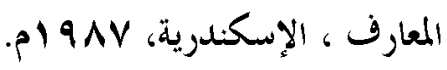




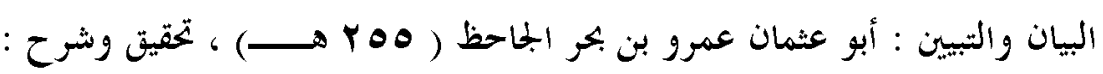

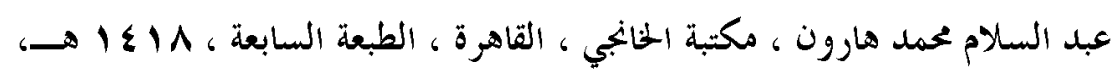
. 1991

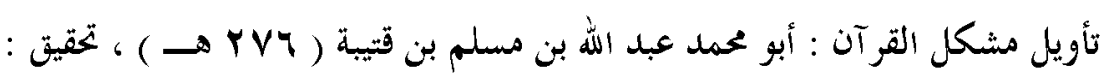

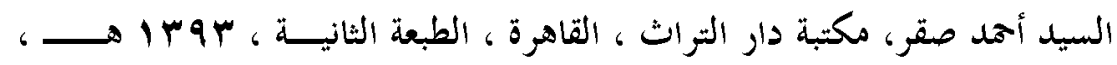
. $19 \mathrm{Vr}$ تحولات البية في البلاغة العربية : د. أسامة البحيري ، دار الحضارة للطباعة والنشر

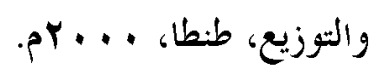

تفاعلات الحداثة في شعر السبعينيات : د. هـ محمد عبد المطلب ، الهيئة العامة لقصــور

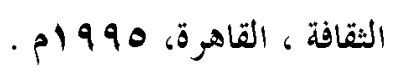

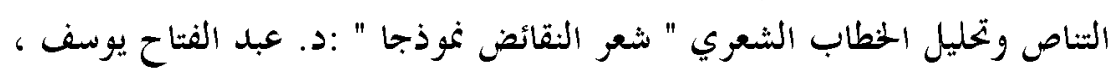

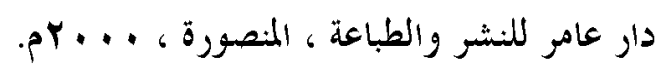

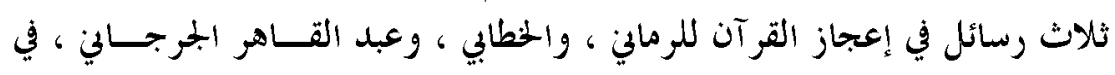

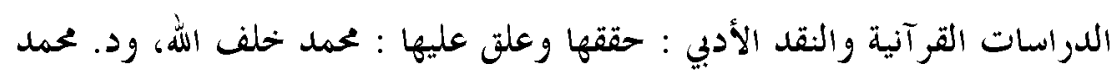

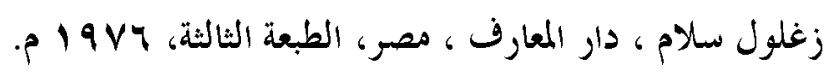

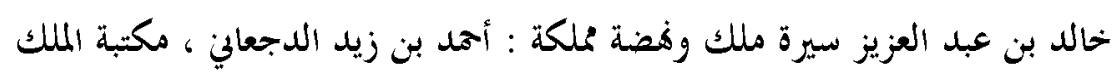

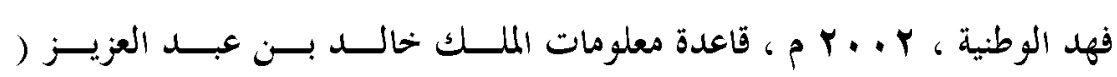

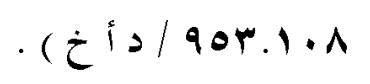
- $\frac{\sqrt{9}}{\frac{9}{3}}$ $r \cdot \Lambda$

الخحصائص : أبو الفتح عثمان بن جني ، تحقيق : محمد علي النجار ، المكتبة العلمية ،

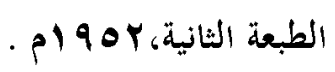
خصائص الأسلوب في الشوقيات : محمد المادي الطرابلسي ، الهيئة المصرية العامــة

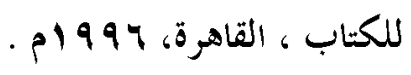
الخطاب الشعري ( استراتيجية التناص) :محمد مفتاح ، المركز الثقافي العربي ، الطبعة ، لهوه

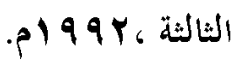
الدعوة في عهد الملك خالد بن عبد العزيز : نمر الحربي ، رسالة جامعيسة ، جامعسـة

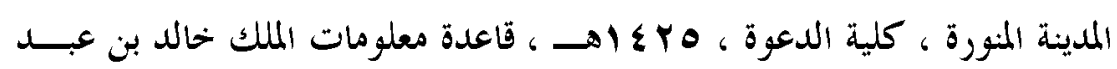

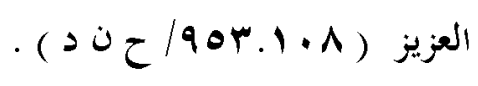




\section{ظاهرة التكرار}

دلالة الزمن في العربية دراسة النسق الزمائ في الأفعال : عبد الجيــد جحفــة، دار

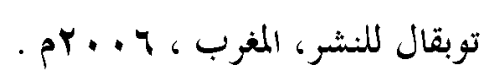

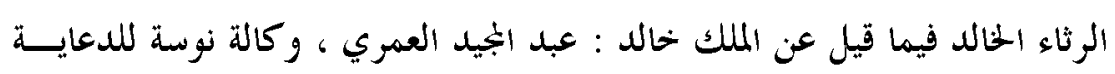

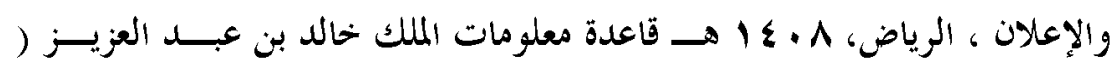

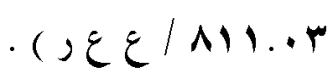

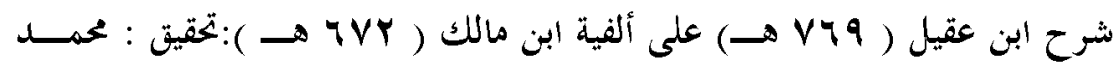

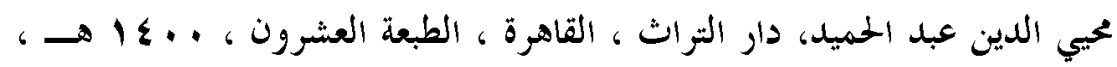
. 9 . شعر الفراق في العصر الجاهلي دراسة أسلوبية : رسالة ماجستير للباحث ، مخطوطة

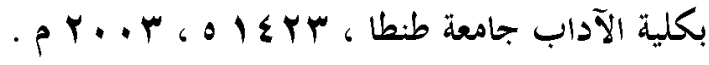

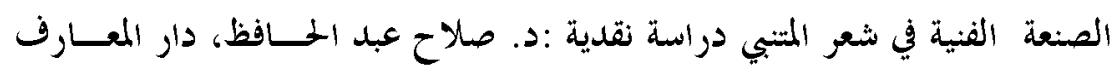

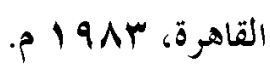

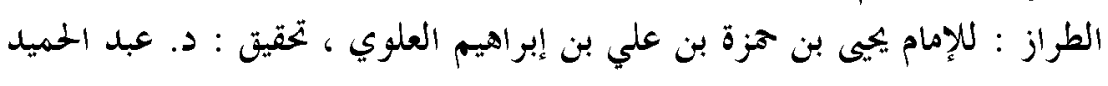

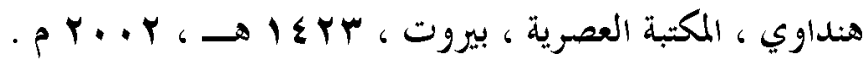

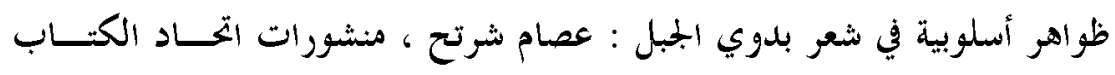

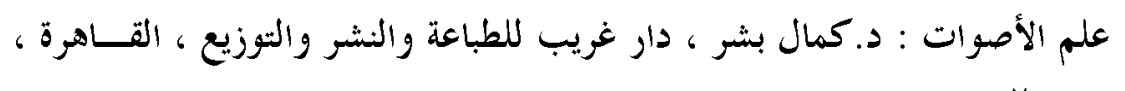
. . .

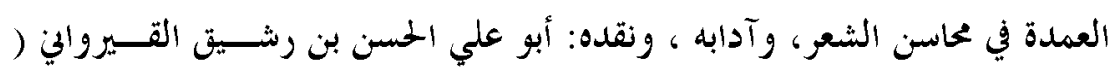

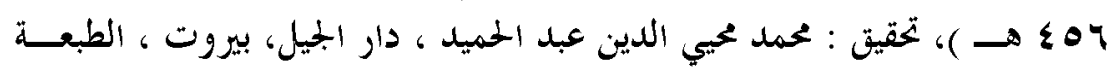

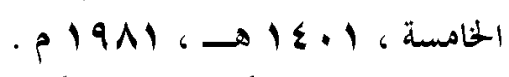

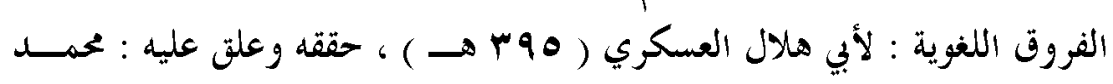

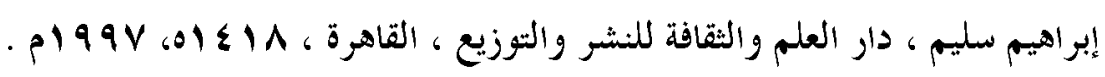

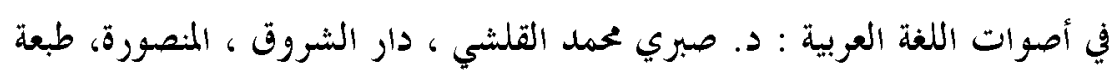

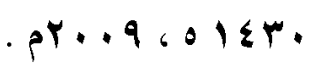
القافية وأثرها في تشكيل النص الشعري " دراسة تطيقية على قصائد اللزوميات " :

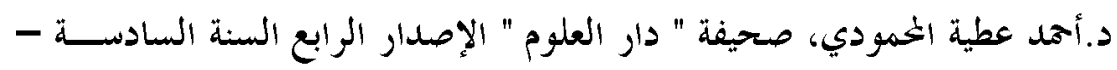

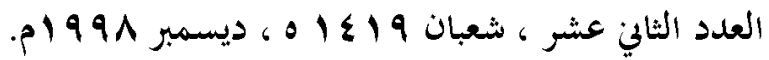


قصايا الشعر المعاصر : نازلك الملائكة ، منشورات مكتبة النهضية ، الطبعة الثالثــة ،

م 194

قضية الأصالة والفرعية في دراسة النحو العربي : د. صلاح بكــــ، ذات النطـاقين

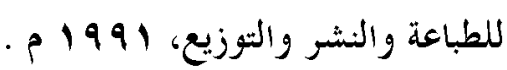

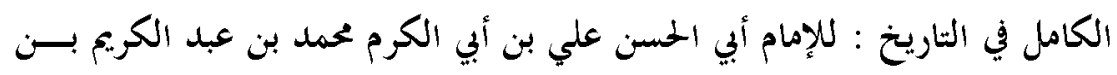

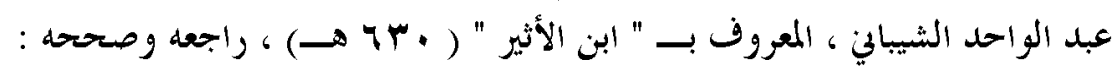

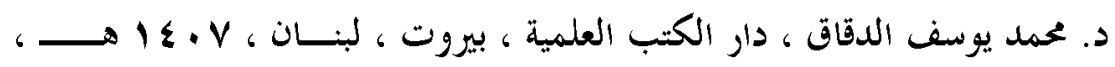
- $19 \wedge \mathrm{V}$

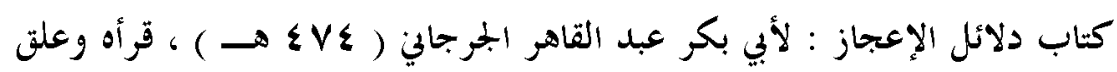

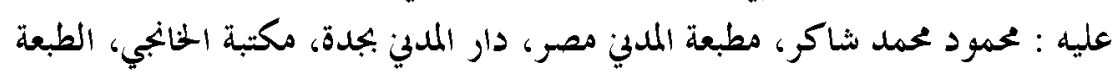

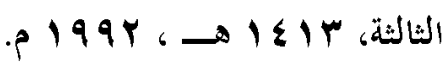

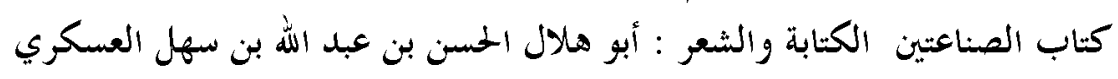

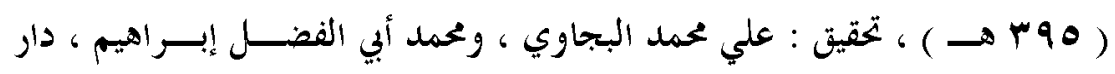

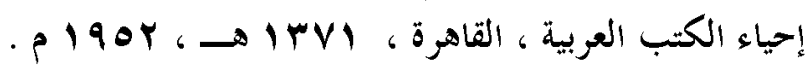

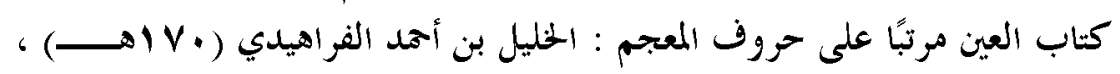

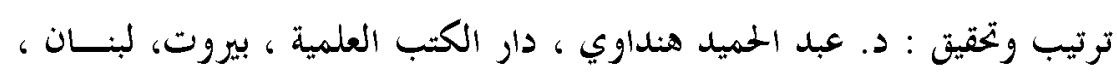
طبعة

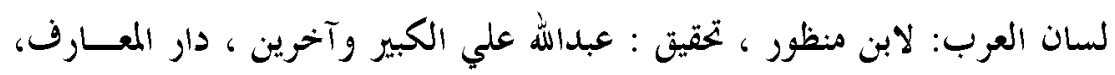

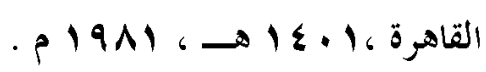

لسانيات النص مدخل إلى انسجام الخطاب، محمد خطابي، المركز الثقــافي العـــي،

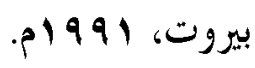

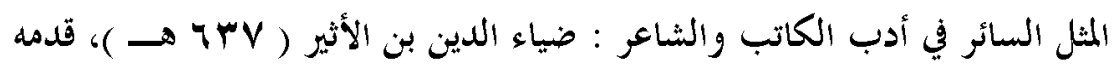

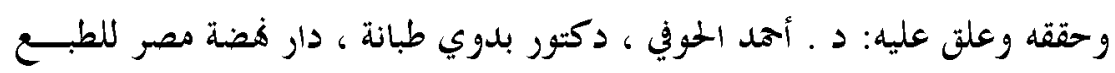

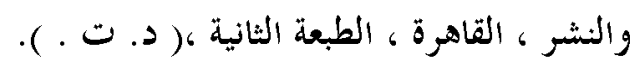

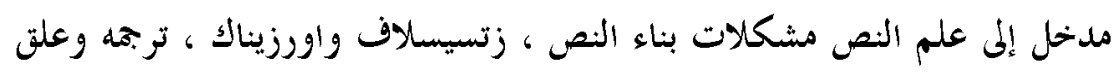

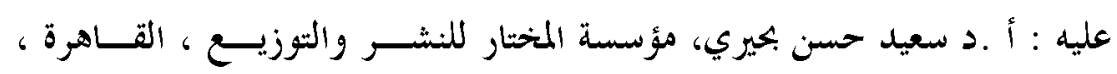

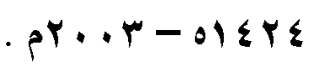




\section{ظعاهرة التكرار}

مستويات البناء الشعري عند محمد إبراهيم أبي سنة، دراسة في بلاغة النص: شكري

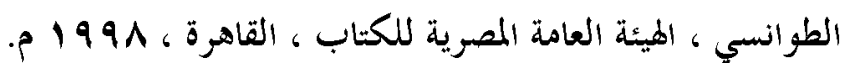

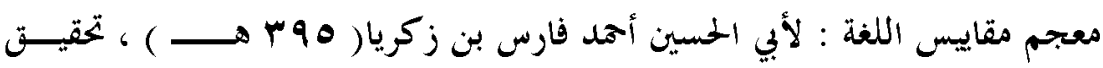

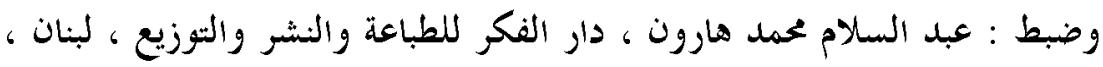
. $19 \vee 9$ ، 1 ، 1 م 99

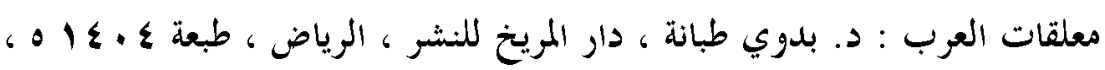

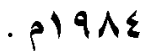

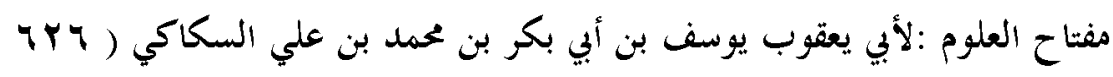

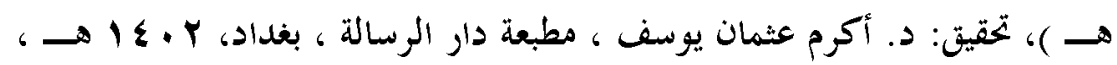

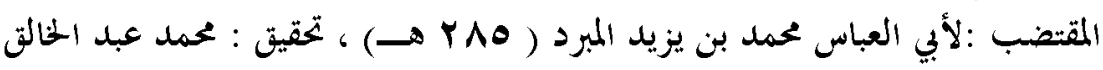

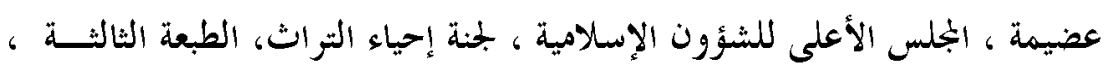
. Yा

الملك خحالد بن عبد العزيز آل سعود دراسة تاريخية وحضارية : نوال الحياط ، رسالة

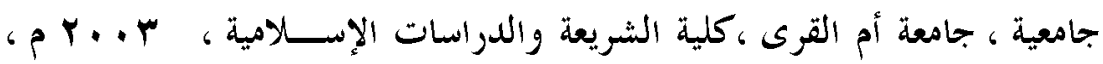

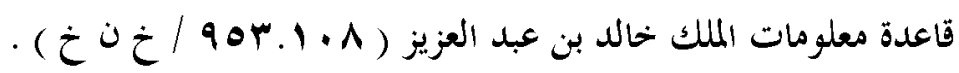

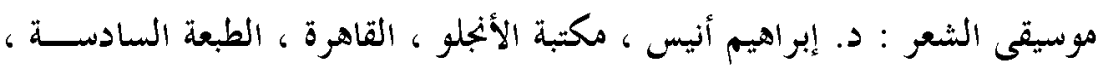
- م $19 \wedge \Lambda$

النظام النحوي : د ـ محمد صلاح بكر ، ذات النطاقين للطباعة والنثر والثوزيع ، . 1991 نظرية اللغة والجمال في النقد العربي : تامر سلوم ، دار الحوار للنشـــــ والتوزيــــ

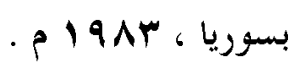
نقد الشعر: قدامة بن جعفر ، تحقيق وتعليق: د. محمد عبد المنعم خفاجي، دار الكنب العلمية ، بيروت، لبنان ، ( د. ت . . ) .

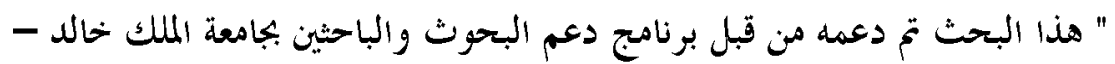

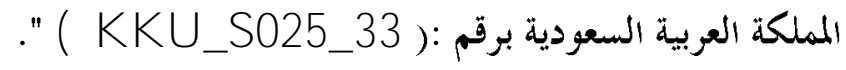


(1) الرثاء الحالد فيما قيل عن الملك خالد : عبد الجيد العمري ، وكالة والة نوسة للدعاية

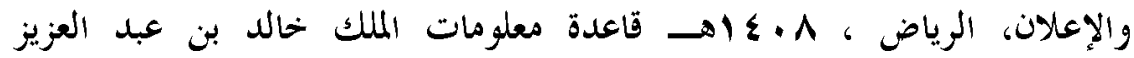

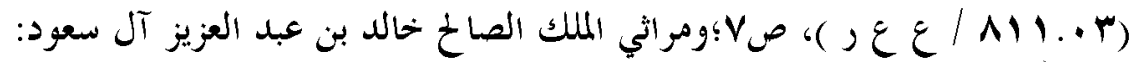

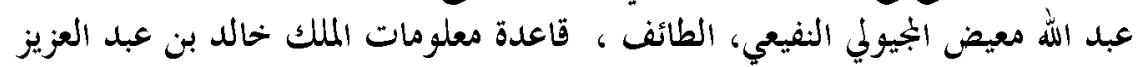

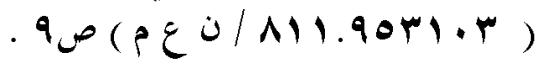

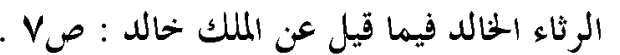

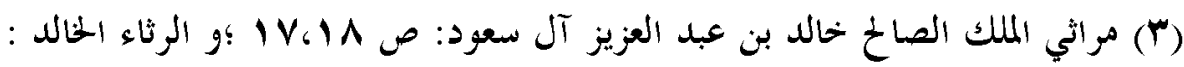

$$
\begin{aligned}
& \text { صV. }
\end{aligned}
$$

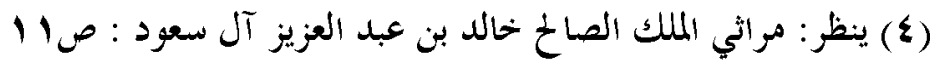

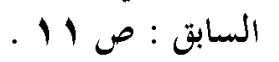

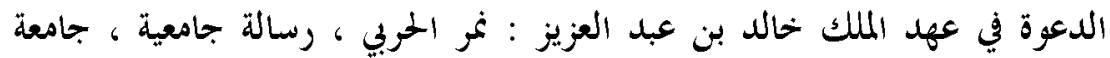

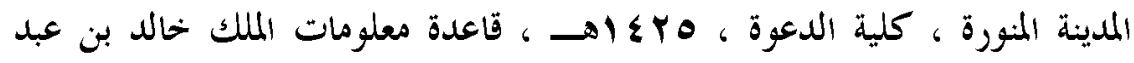

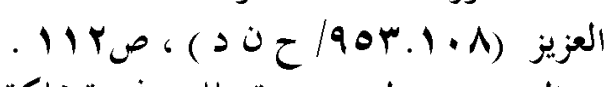

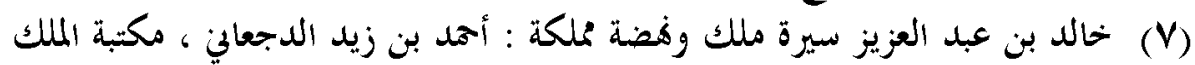

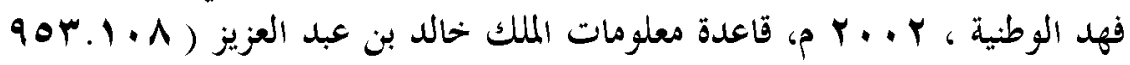

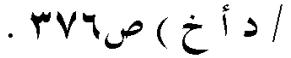

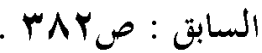

(9) انظر : البيان والنبيين : أبو عثمان عمرو بن بحر الجاحظ (

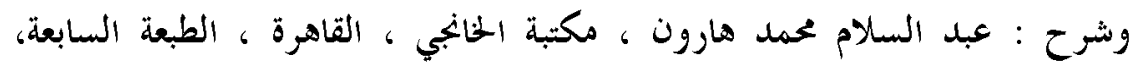

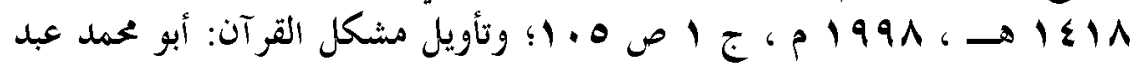

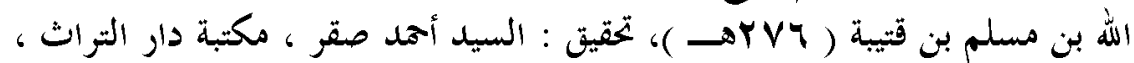

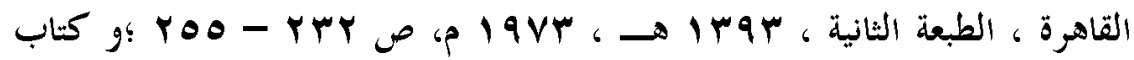

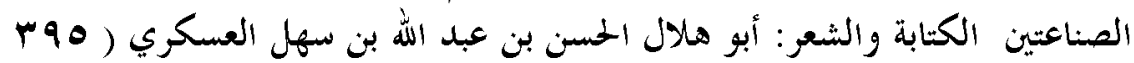

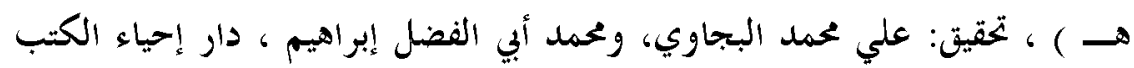

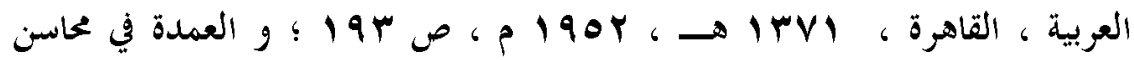

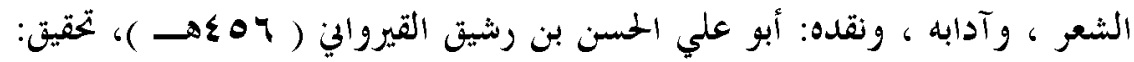

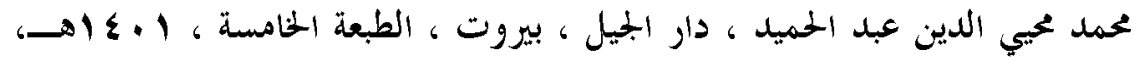

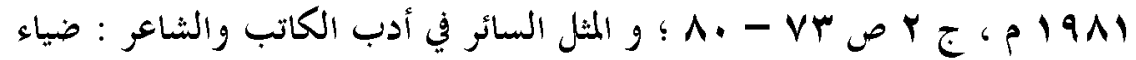

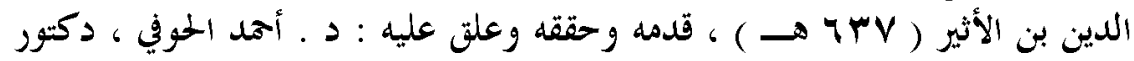

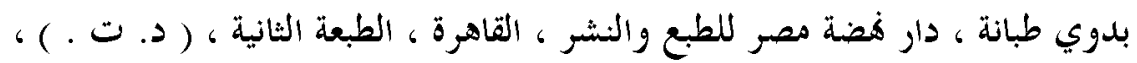




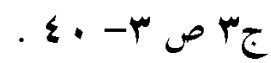

(• (1) قضايا الشعر المعاصر : نازك الملائكة ، منشورات مكتبة النهضة ، الطبعة الثالثة ،

YEY ص م 197V

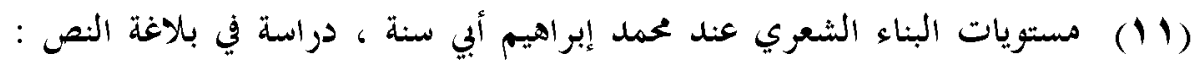

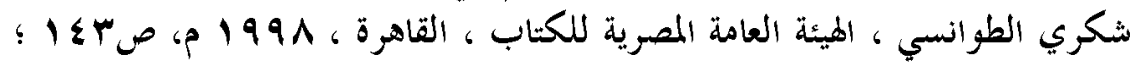

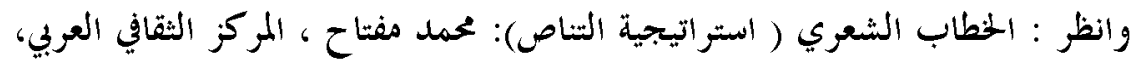

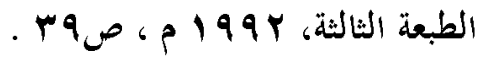

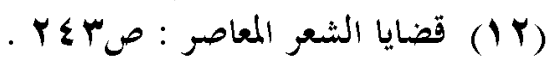

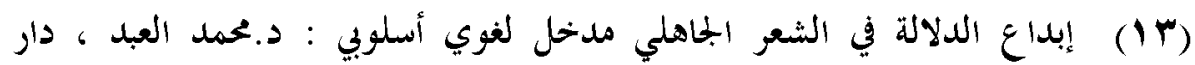

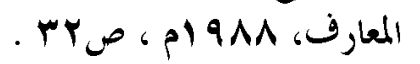

牙

rit

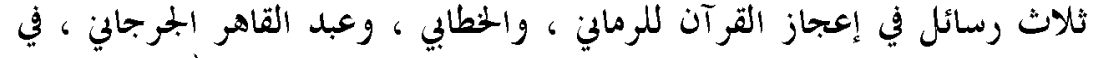

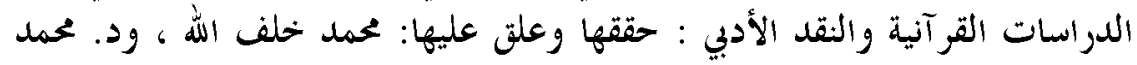

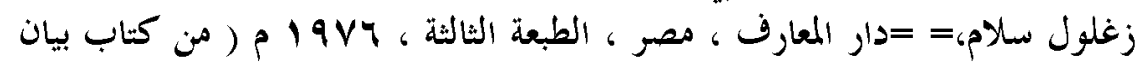

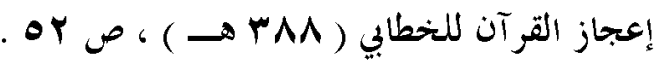

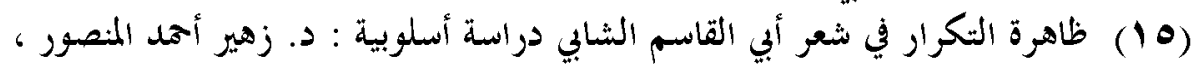

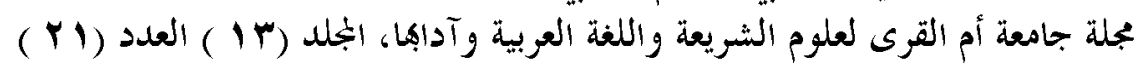

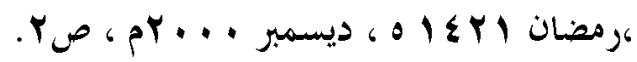

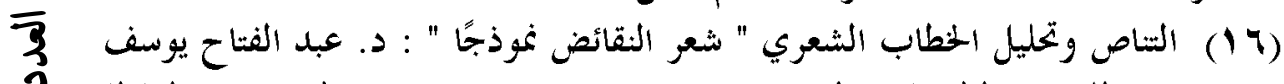

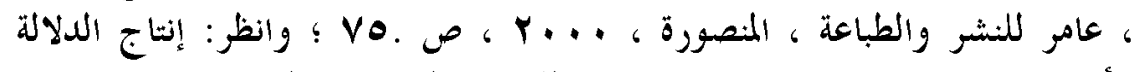

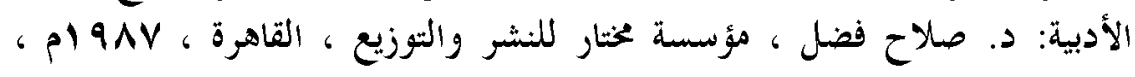
ص PVO

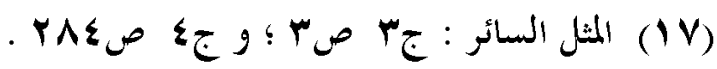

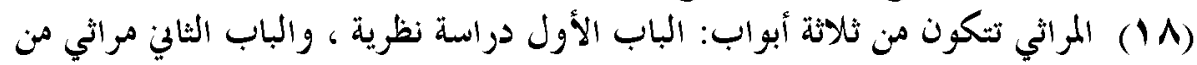

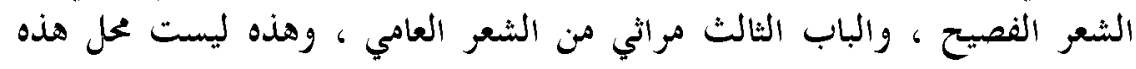
الدراسة.

(9 (1) يُنظر: في أصوات اللغة العربية : د. صبري محمد القلشي ، دار الثروق ، المنصورة

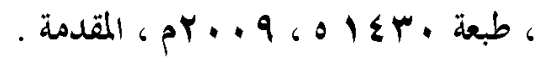

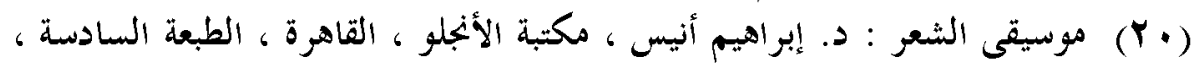

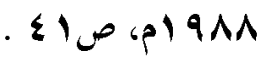

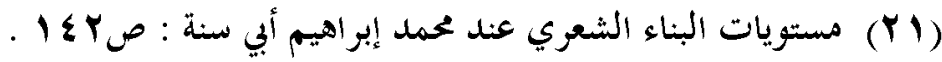

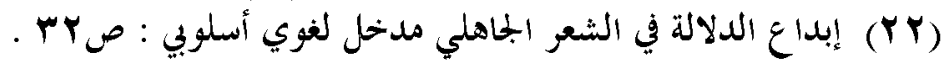

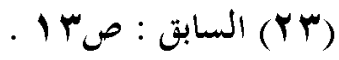




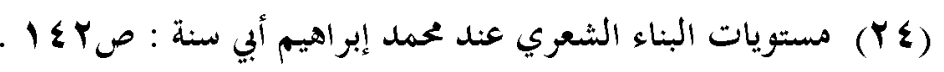
(Y)

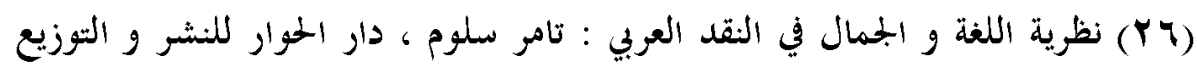

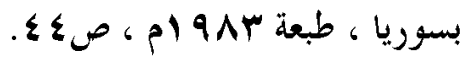

$$
\begin{aligned}
& \text {. }
\end{aligned}
$$

(Y^)

$$
\text { صه }
$$

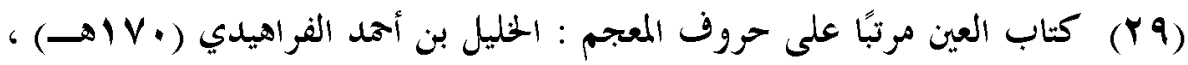

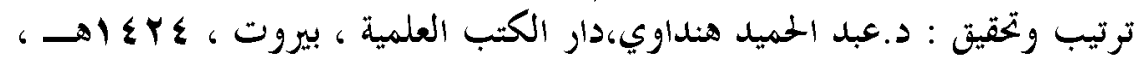

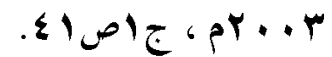

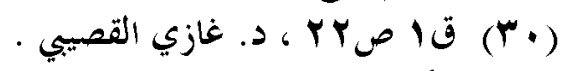

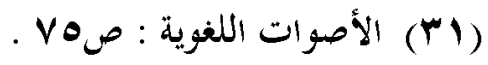

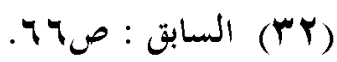

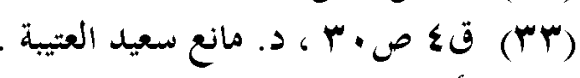

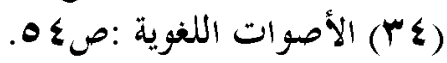

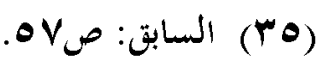

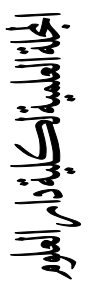

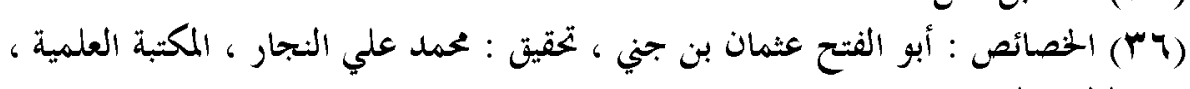

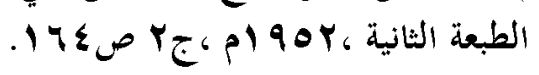$$
\text { (r) (rV) }
$$

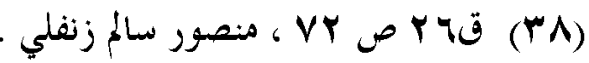

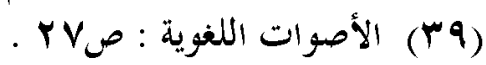

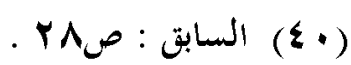

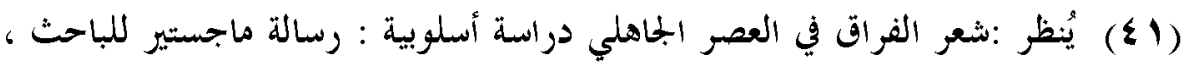

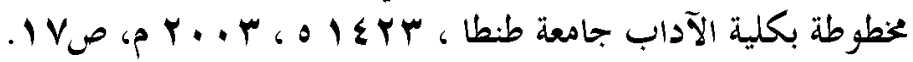

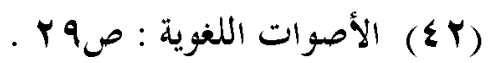

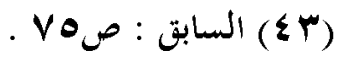

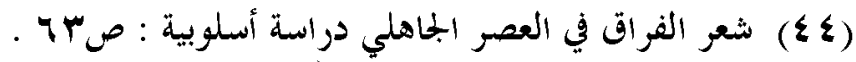

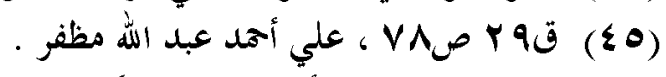

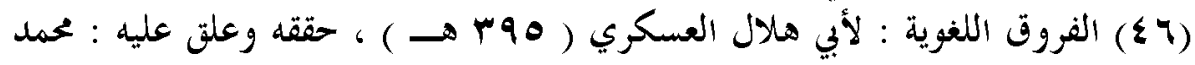

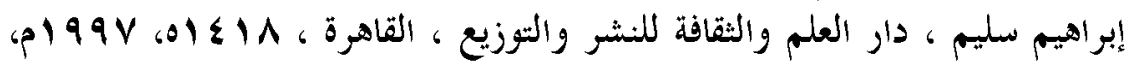




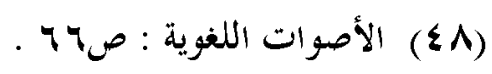

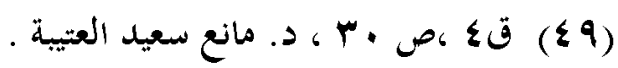

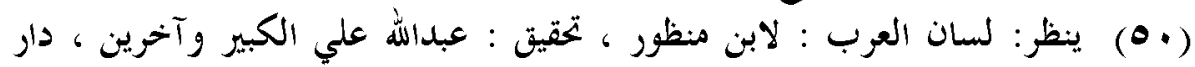

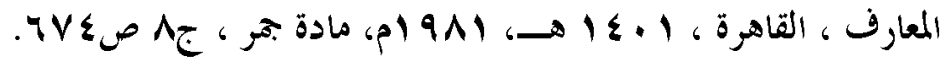

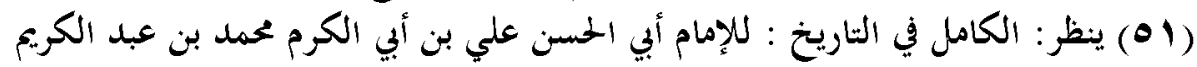

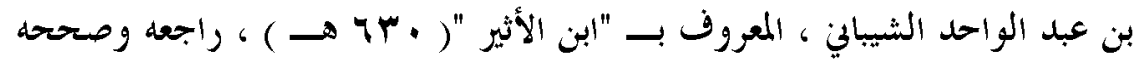

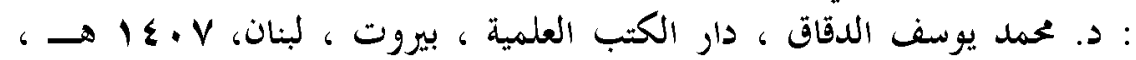

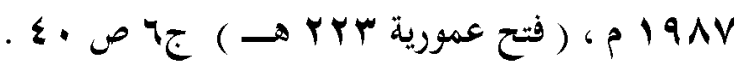

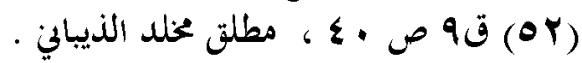

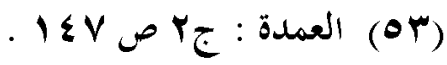

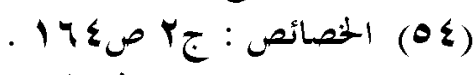

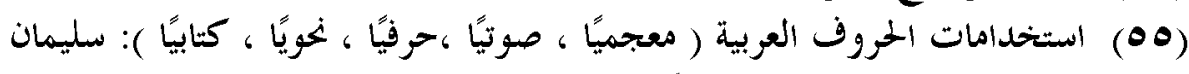

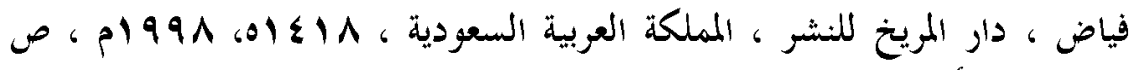

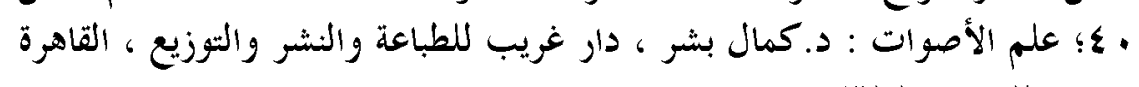

، ....

Y10

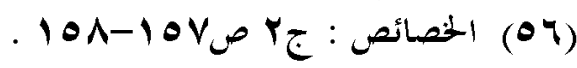

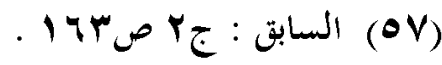

$\overline{3}$

(O^)

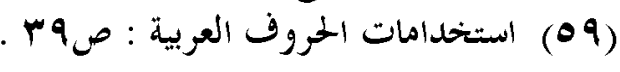

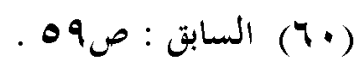

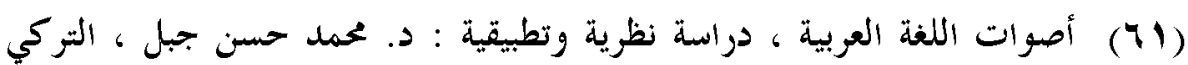

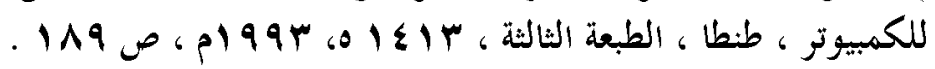

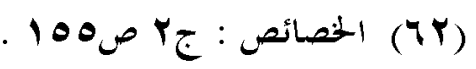

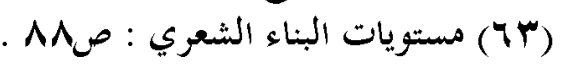

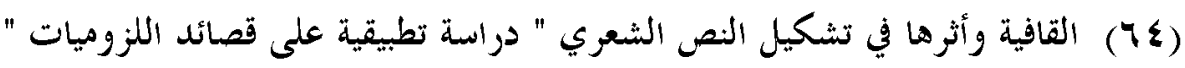

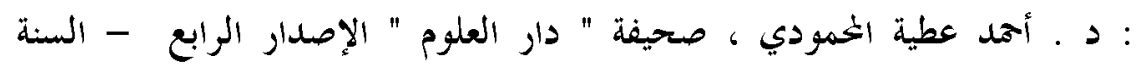

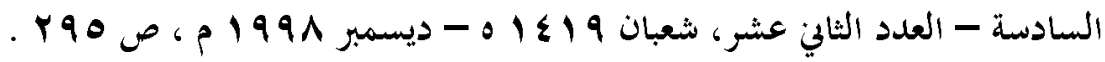

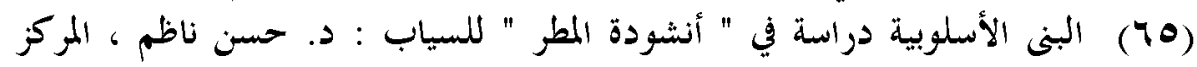

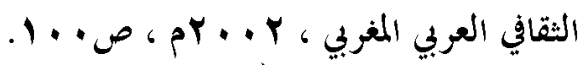

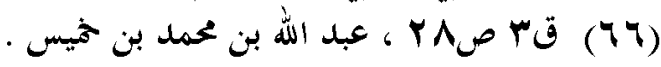

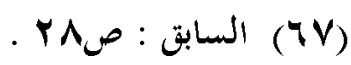

( ) 


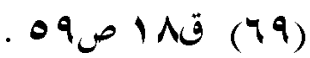

• الرقم (1) إنارة إلى رقم الييت في القصيدة.

(V•)

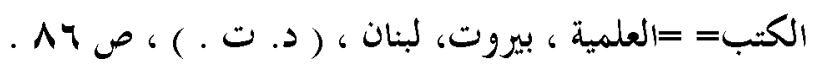

. (VI)

أمعات (VT)

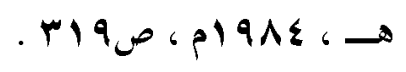

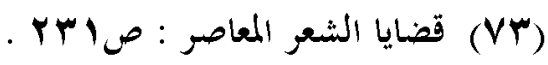

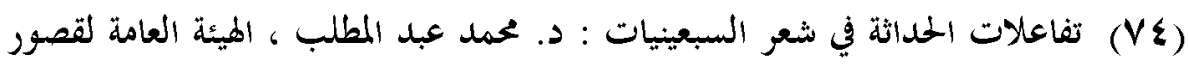

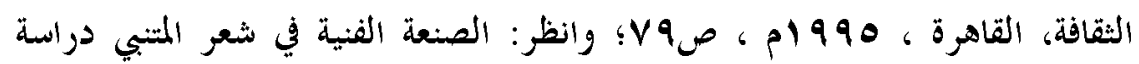

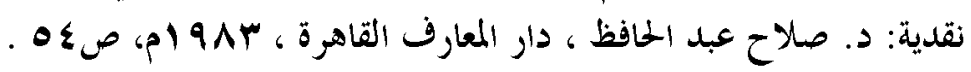
(VO)

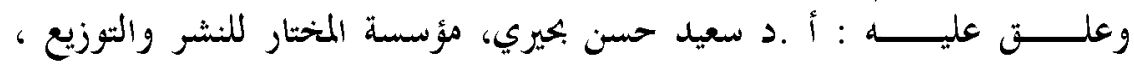

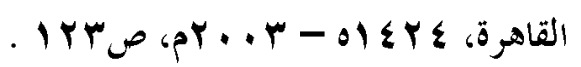

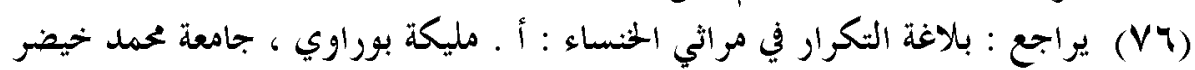

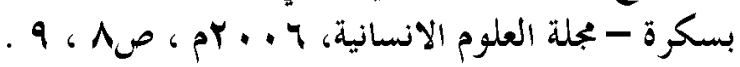

$$
\begin{aligned}
& \text { (VV) }
\end{aligned}
$$

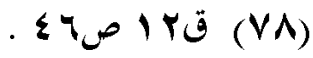

$$
\begin{aligned}
& \text {. Vq - VY العمدة : (Vq) }
\end{aligned}
$$

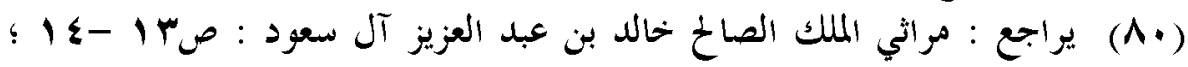

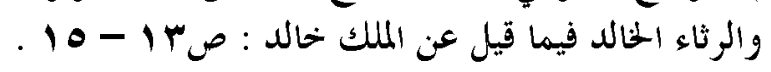

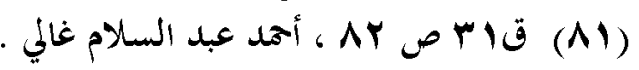

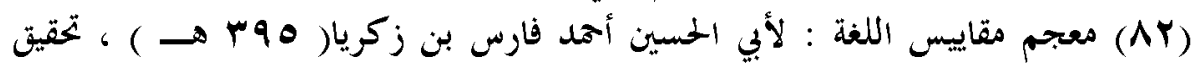

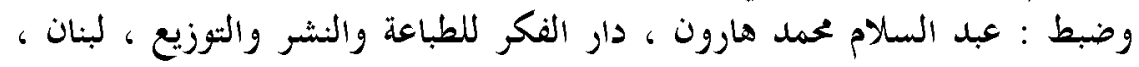

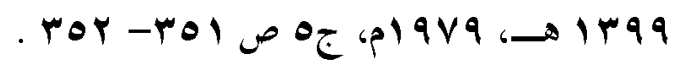

(Ar)

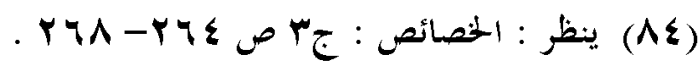

)

$$
\text { (AY) }
$$

، لسانيات النص مدخل إلى انسجام الخطاب ، محمد خطابي ، المركز الثقافي العربي (AV)

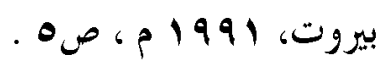

(AN) 


\section{ظاهرة التكرار}

(199) يراجع : الاتساق والانسجام في سورة الكهف : مذكرة مقدمة لنيل شهادة

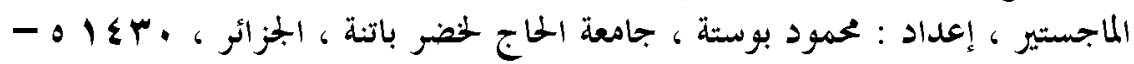

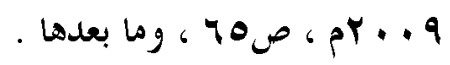

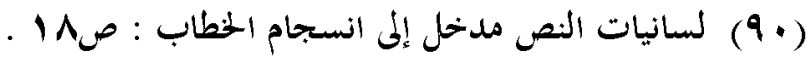

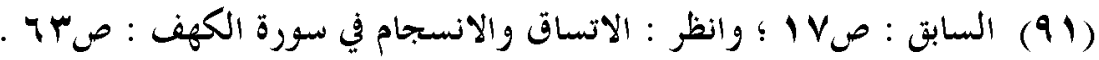

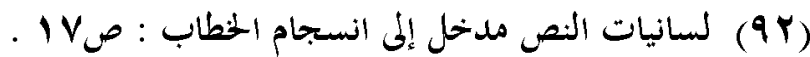

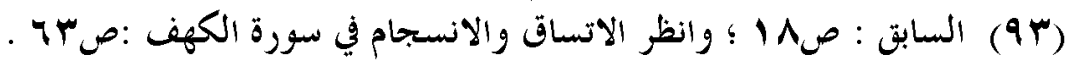

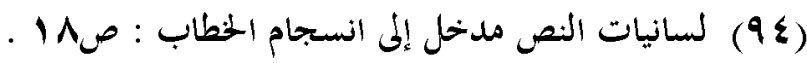

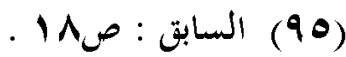

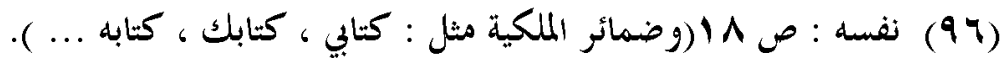

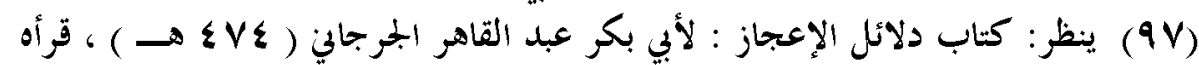

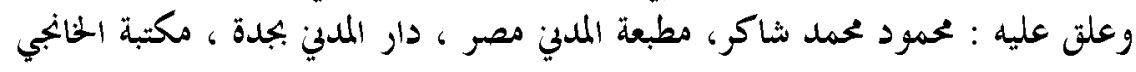

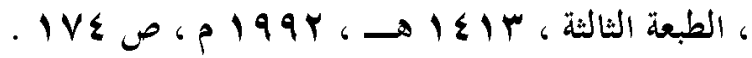

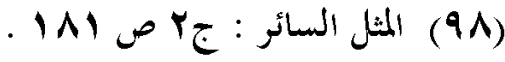

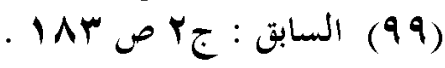

rIV

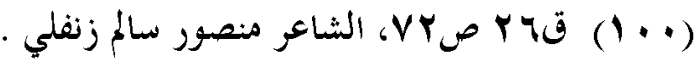

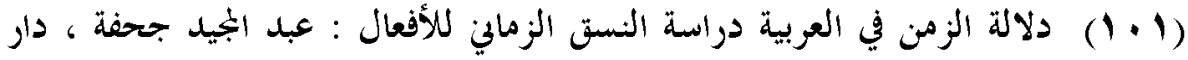

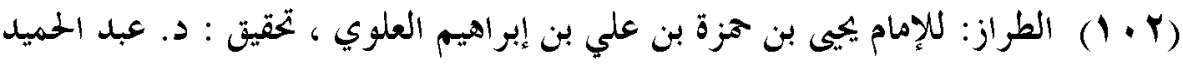

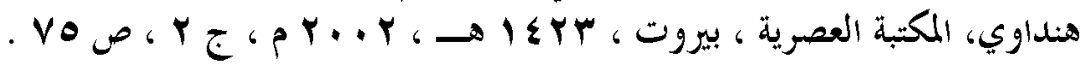

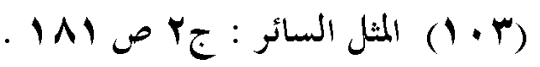

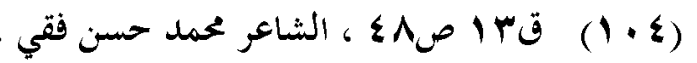

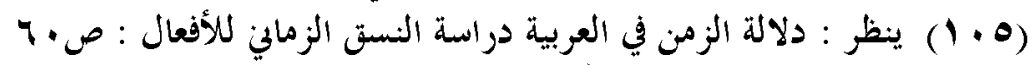

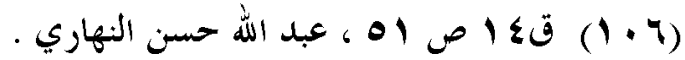
(l.V)

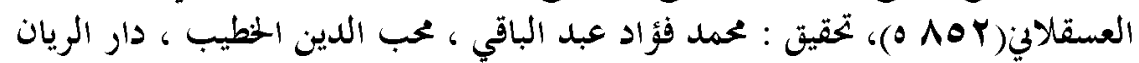

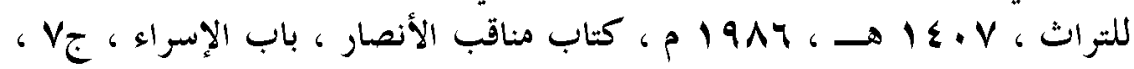

$$
\text { ص م }
$$

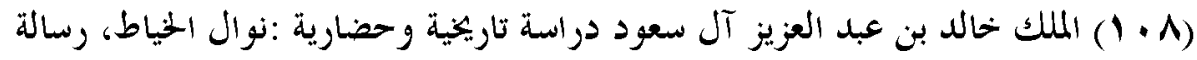

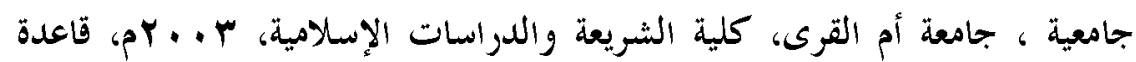

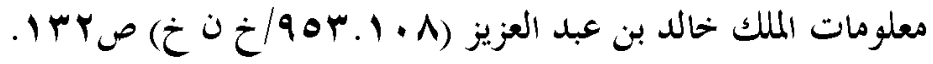

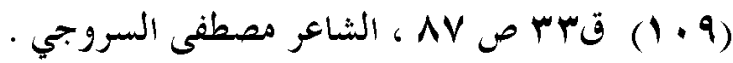




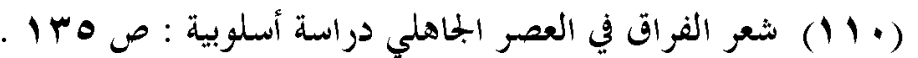

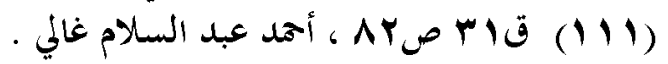

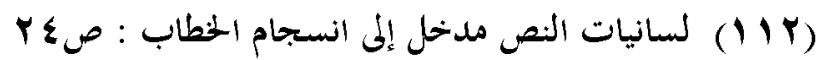
.

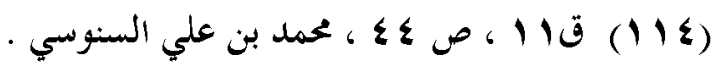

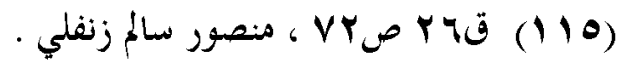

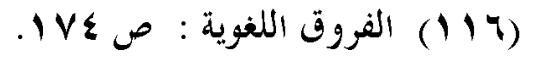
(IV)

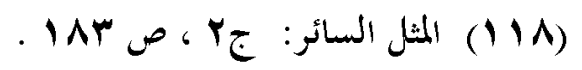

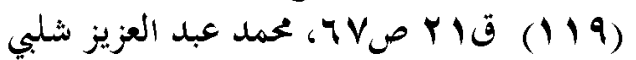
(IY.)

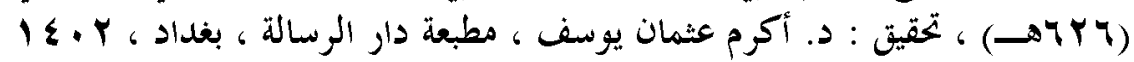

$$
\text { هـ ، ا }
$$

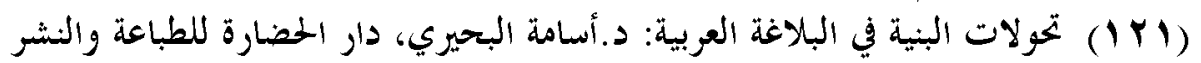

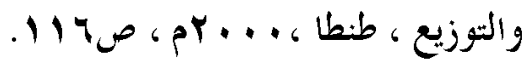

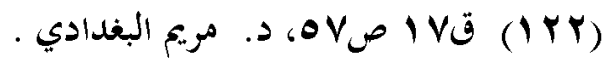

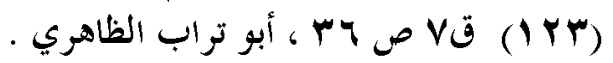

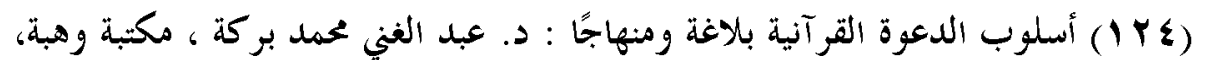

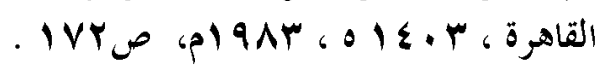

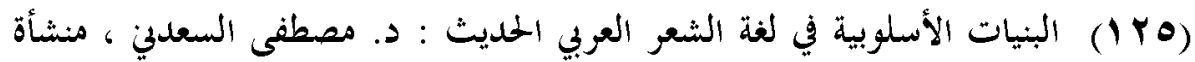

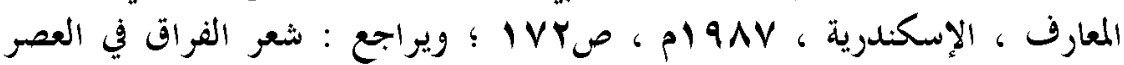

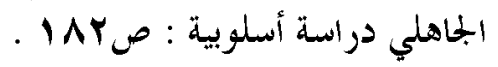

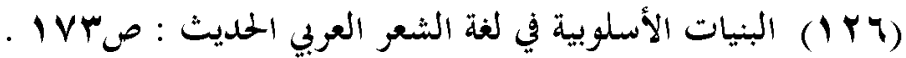

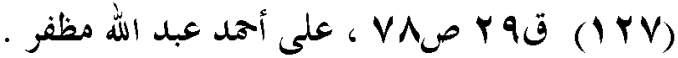

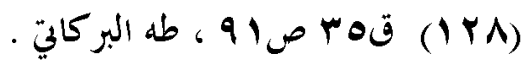

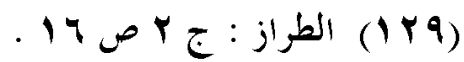

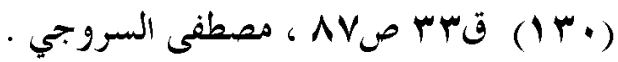

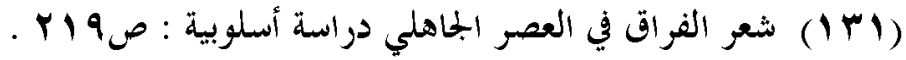

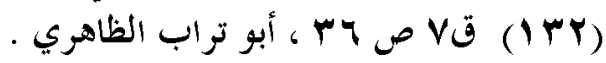

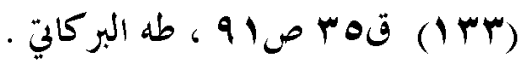

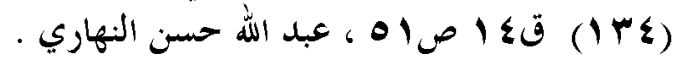

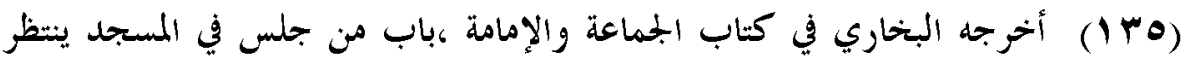




\section{ظاهرة التكرار}

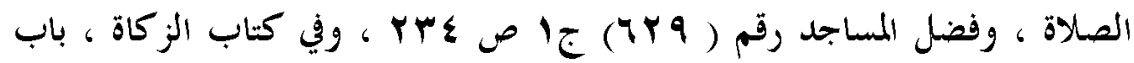

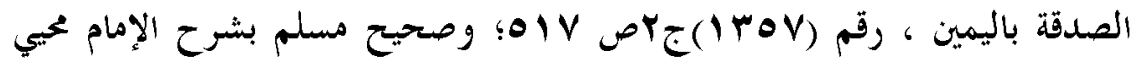

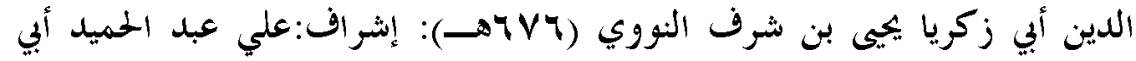

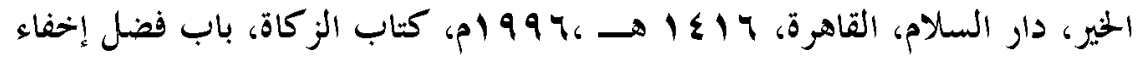

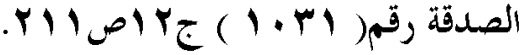

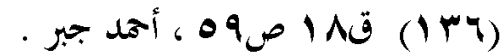

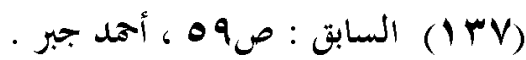

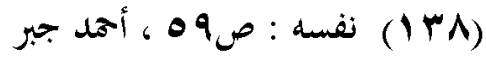

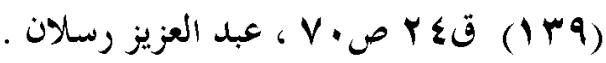

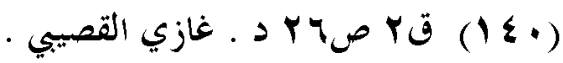

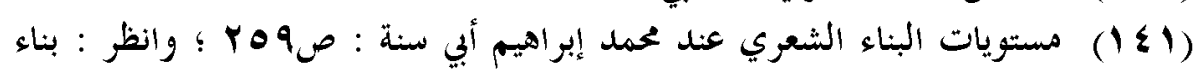

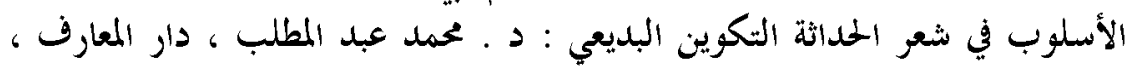

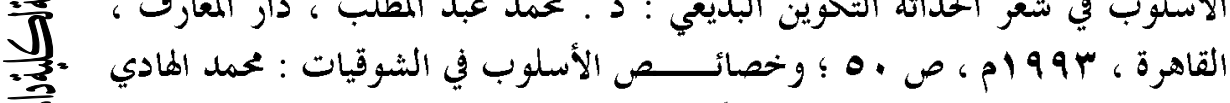

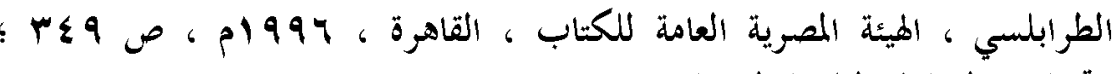

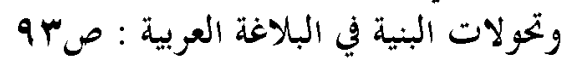

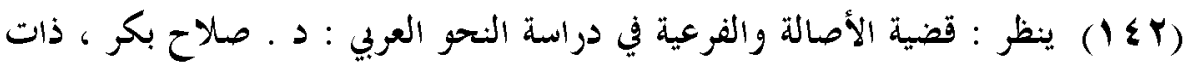

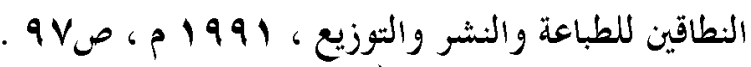

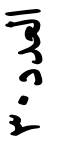

.

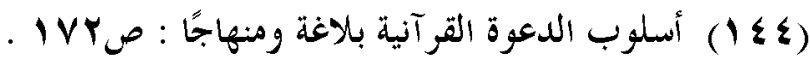

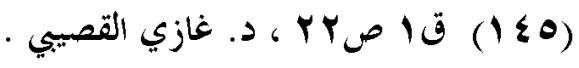

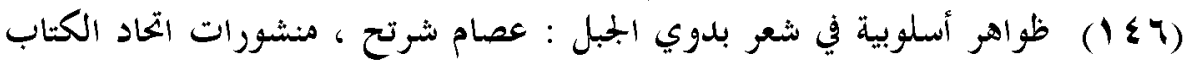

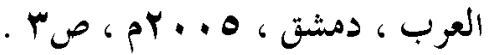

$$
\begin{aligned}
& \text {. Y }
\end{aligned}
$$

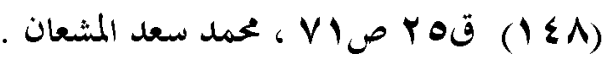

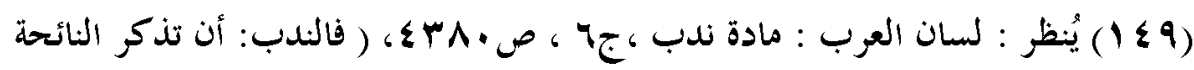
الميت بأحسن أوصافه وأفعاله ).

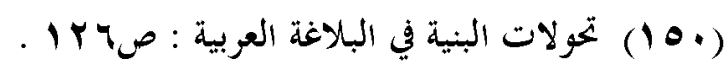

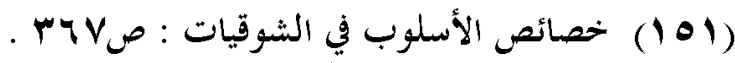

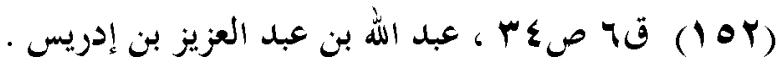

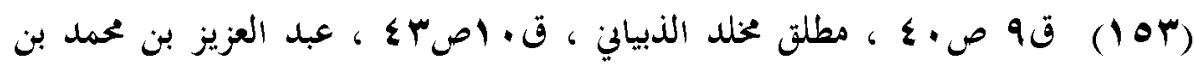

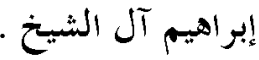

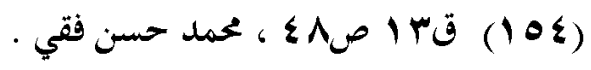




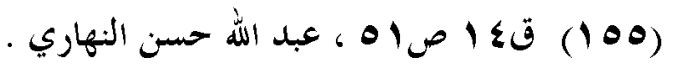

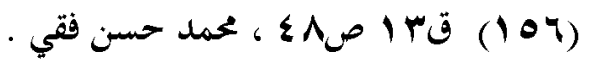

$$
\begin{aligned}
& \text { (lهV) }
\end{aligned}
$$

(10^)

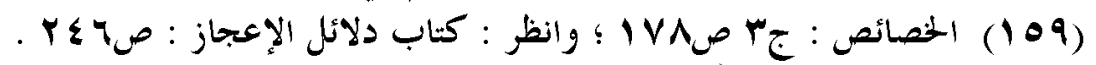

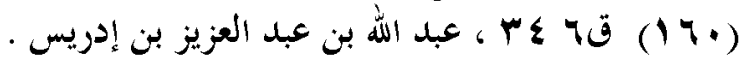

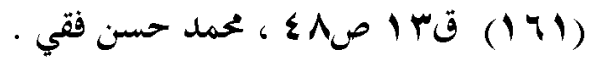

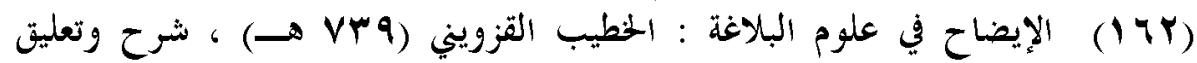

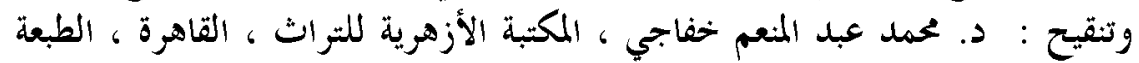

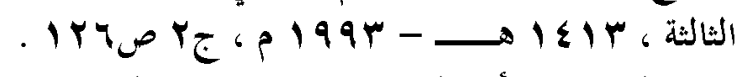

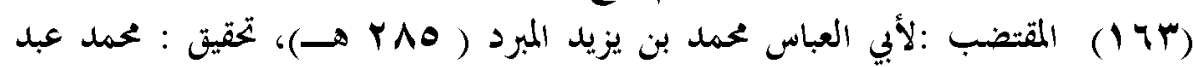

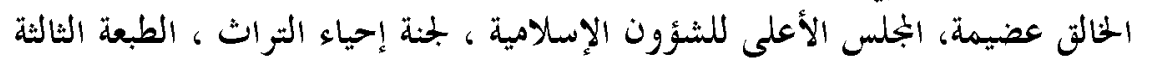

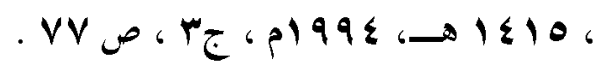

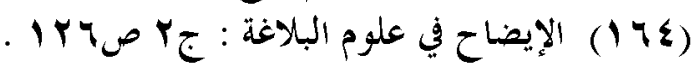

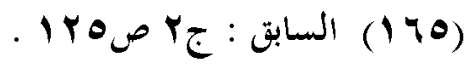

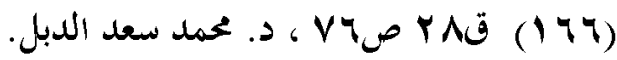

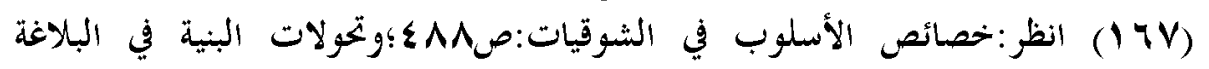

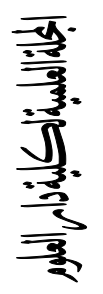

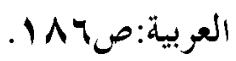

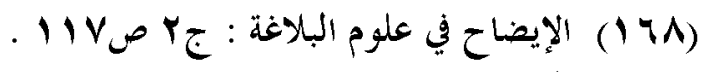

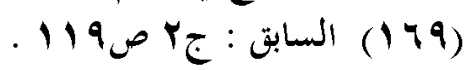

(IV•)

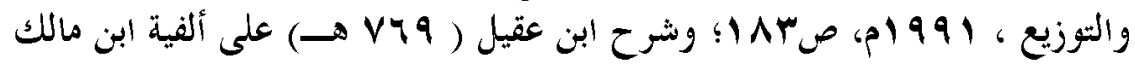

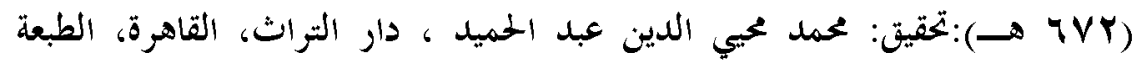

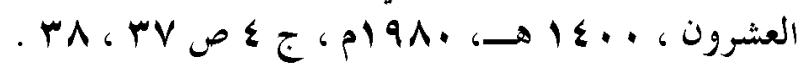

